T 1952

\title{
A GEOCHEMICAL SURVEY OF STREAM SEDIMENTS \\ OF THE PICEANCE CREEK BASIN, COLORADO
}

\section{NOTICE}

PORTIONS OF THIS REPORT ARE ILLEGIBLE. It

has boon reproduced from the best avallable

copy to permit the broadest possible avall-,

ability. . L

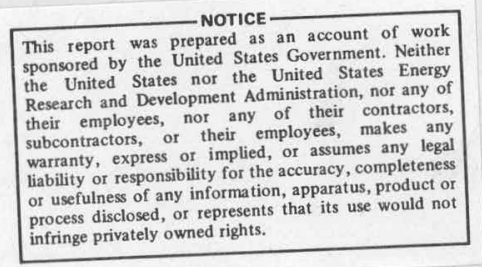

by

Charles D. Ringrose

MASTER 


\section{DISCLAIMER}

This report was prepared as an account of work sponsored by an agency of the United States Government. Neither the United States Government nor any agency Thereof, nor any of their employees, makes any warranty, express or implied, or assumes any legal liability or responsibility for the accuracy, completeness, or usefulness of any information, apparatus, product, or process disclosed, or represents that its use would not infringe privately owned rights. Reference herein to any specific commercial product, process, or service by trade name, trademark, manufacturer, or otherwise does not necessarily constitute or imply its endorsement, recommendation, or favoring by the United States Government or any agency thereof. The views and opinions of authors expressed herein do not necessarily state or reflect those of the United States Government or any agency thereof. 


\section{DISCLAIMER}

Portions of this document may be illegible in electronic image products. Images are produced from the best available original document. 
A Thesis submitted to the Faculty and the Board of Trustees of the Colorado School of Mines in partial fulfillment of the requirements for the degree of Master of Science in Geochemistry.

Signed: Charles D. Ringrose

Golden, Colorado Date: 1977

Approved: Ronald W. Klusman Thesis Advisor
George H. Kennedy Head of Department

Golden, Colorado

Date:

1977 


\section{ABSTRACT}

A stream sediment survey was conducted in the Piceance Creek basin to study the spatial distribution of $\mathrm{Zn}$, Mo, Hg, $\mathrm{Cd}$ and As for future baseline considerations. The $\mathrm{pH}$ and organic matter were also measured. From samples taken at the mouths (junctions) of most of the named creeks in the basin, it is concluded that none of the streams contained sediments with anomalous trace element concentrations with respect to the basin. But it is thought that Mo and possibly As could be potentially toxic because of their abundance and their mobility under the stream sediments' alkaline condition.

From a different sampling plan, designed to describe the background variance of five streams (Roan, Black Sulfur, Parachute, Yellow and Piceance Creeks), it was found that most of the variance occurred at distances from 0-10 $\mathrm{m}$ within $2 \mathrm{~km}$ stream segments $10 \mathrm{~km}$ apart for $\mathrm{MO}, \mathrm{Hg}, \mathrm{Zn}$, and organic matter. When the variance between the five streams was considered, it was found to dominate the variances of the other factors for Mo, $\mathrm{Hg}$, and $\mathrm{Zn}$. This variance between streams is actually thought to represent the variance between the major drainage system in the basin.

When comparison is made between the two sampling design results, it is thought that the trace element concentrations of stream junction samples represented the best range of expected values for the entire basin. The expected ranges 
of the trace elements from the nested design are thought to be reasonable estimates of preliminary baselines for Parachute Creek, Roan Creek and Black Sulfur Creek within the restricted limits of the streams defined in the text. From the experience gained in pursuing this study, it is thought that composite sampling should be considered, where feasible, to reduce the analytical load and to reduce the small scale variance. 
TABLE OF CONTENTS

Page

ABSTRACT . . . . . . . . . . . . . . i ii

ACKNOWLEDGMENTS. . . . . . . . . . . . . viii

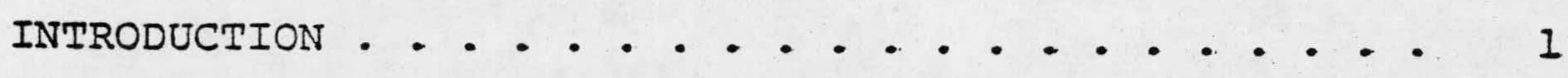

GEOLOGICAL AND GEOCHEMICAL SETTING . . . . .... 3

CHEMICAL ANALYSIS. . . . . . . . . . . . 9

SAMPLE DESIGN. . . . . . . . . . .... 10

INTERPRETATION OF NESTED SAMPLE DESIGN ........ 16

Definition of Models and Variables. . . .... 16

Interpretation of the Nested Samples.: $\because .918$

INTERPRETATION OF THE STREAM JUNCTION DESIGN •.... 28

NESTED VS. STREAM JUNCTION RESULTS......... 39

CONCLUSIONS.................. 41

APPENDIX A .................. . . 43 43

Sampling Procedure and Sample Processing..... 43

Analysis. .............. 44

APPENDIX B...................... 4 49

Comments on the Application of Equations. . . 49

Computer Programming. . . . . . . . . . 51

Plotter Program. . . . . . : : 52

One-Way Analysis of Variance Program . . . 54

Nested Analysis of Variance Program. . . : 68

Censored Data........... 84

REFERENCES ..................... 99 


\section{IIST OF FIGURES}

Figure

Page

1. Simplified geological map of the study are.$:$ : i -

2. Cross section of stratigraphic section in

Piceance Creek basin. . . . . . . . . .

3. Sampling distribution at stream junctions in study area. . . . . . . . . . . . . 11

4. Boundaries of the nested model. . . . . . . . 13

5. Detailed breakdown of nested sample design. . . I4

6. Diagram of nested model for each individual stream. . . . . . . . . . . . . 15

7. Typical cumulative variance curve for streams with large percent of variance at low scale . . . 22

8. Histogram for Mo in Piceance Creek. . . . . . 33

9. Histogram for $\mathrm{Zn}$ in Piceance Creek. ...... . 34

10. Spatial distribution of high and low concentrations of Mo from histogram of figure $8 . . .$. .

11. Spatial distribution of high, medium, and low concentrations of $\mathrm{Zn}$ from histogram of figure 9............... 36

12. Sample results of plotter progran . . . . . . 54

13. Nested model of Roan Creek using Mn data. . . . 72

14. Nested model of Black Sulfur Creek using Mn data. 73

15. Nested model representing both creeks using Mn data... . . . . . . . . . . . . . 


\section{LIST OF TABLES}

Table

Page

1. X-ray fluorescence analysis of selected Piceance basin rock samples . . . . . . . 7

2. Geographic scales of variance components. . . . 18

3. Geochemical summaries for stream sediments of major creeks in Piceance basin......... 19

4. Stream mean groupings for $\mathrm{Zn}, \mathrm{Mo}, \mathrm{Hg}$ and organic matter............... 25

5. Stream junction data for each element...... 30

6. Comparison between stream junction and nested expected ranges for individual streams. . . . . 32

7. Listing of the plotter program. . . . . . 53

8. Listing of program which regroups one constituent at a time from Table 9 for the one-way analysis subroutine program . . . . .

9. List of stream junction analyses for each stream locality . . . . . . . . . . . .

10. Iisting the output of program listed in Table 8 ................ 63

11. Listing of the one-way analysis program..... 69

12. Listing the output of program listed in Table 11. 70

13. Listing of input for program listed in Table 15. 74

14. Iist of input for program listed in Table 15. . 77

15. Iisting of program for calculating the analysis of variance for unbalanced nested design. . . . . . . . . . . . . .

16. Listing of output of program listed in Table 15. 81

17. Listing of censored data program. . . . . . 85

18. A-Input data for program listed in Table 17... 89 B-Output data for program listed in Table 17. . . 89 
Table

19. Listing of nested analyses for each stream location. . . . . . . . . . . 90

20. Analysis of variance results for the nested stream models............... 94 - 


\section{ACKNOWLEDGMENTS}

Financial support for this work was derived in part from the Colorado Energy Research Institute and the Biomedical and Environmental Research Division of the Energy Research and Development Administration, contract number ERDA E(1I-1)4017 .

It should be mentioned that the assistance from $R$. R. Tidball, J. McNeal, and A. T. Miesch of the U.S.G.S. more than compensated for their use of the thesis samples, as most of the sampling and statistical techniques utilized throughout this thesis have been extended from their work.

And finally I want to thank my thesis advisor, Prof. Ronald Klusman, for all the patience he had with me throughout this ordeal of learning something about sampling. 


\section{INTRODUCTION}

The anticipation of an oil shale industry in Colorado, Utah and Wyoming has generated a strong interest in the environmental impact which would result from extracting hydrocarbons from the oil shale rock. In the area of regional geochemistry, ground work has already begun on the spatial distribution of elements and compounds in soils (Ringrose, et al., 1976), and in stream sediments (MCNeal, et al., 1976). Preliminary baseline studies, such as the above referenced, must preclude studies dealing with the changes in distribution of elements and compounds resulting from energy developments.

This thesis also investigates the spatial distribution of trace elements in stream sediments. The similarity between the thesis and the study by McNeal, et al. (1976) is due to U.S. Geological Survey analyses of part of the samples collected in the early stages of this thesis. Thus the objectives of the two studies overlap somewhat, but as will be shown, the thesis work complements the McNeal, et al. (1976) study.

The objectives of the thesis are twofold: 1) to determine if any of the streams of the Piceance Creek Basin contain abnormally high trace element concentrations in their sediments, and 2) to determine the geochemical variation of the sediments from five streams (Roan, Black Sulfur, Para- 
chute, Piceance, and Yellow Creeks) for the purpose of providing sampling interval information for future baseline studies. A knowledge of any streams containing anomalously high trace element concentrations will be important for mak- ing recommendations for any future oil shale plant sites. The possibility of anomalies were not considered in the McNeal, et al. (1976) study. The five selected streams are important because just about any future plant site drainages would eventually enter one of the stream systems included in this study. The McNeal, et al. (1976) study discussed only Roan and Black Sulfur Creeks. 
GEOLOGICAL AND GEOCHEMICAL SETTING

The Piceance Creek basin is a major structural feature of the Colorado Plateau physiographic province. The hasin is bordered on the north by the White River, on the east by the Grand Hogback and the Elk Mountains, on the south by the West Elk Mountains, on the southwest by the Uncompahgre Plateau, and on the west by the Douglas Creek Arch. The topographically high areas within the basin are the Roan Plateau, Battlement Mesa, and Grand Mesa. The extent of the study area is shown in Figure 1, which is a modification of Plate 48 (Donnell, 1961) with the Unita formation replacing the Evacuation Creek member (Cashion, et al., 1974). The main watersheds are the Piceance and Yellow Creeks which drain into the White River, and Roan and Parachute Creeks which drain to the Colorado River.

Stratigraphically the Piceance Creek basin consists of the sandy Uinta formation (Cashion, et al., 1974) overlying the Green River formation which contains the oil shale. Figure 2, which is a modified cross section from plate 48 of Donnell (1961) with the Uinta formation replacing the Evacuation Creek member (Cashion, et al., 1974), illustrates the stratigraphic sequence of the various members and formations. The cross section of Roehler (1974) is in much greater detail. The Green River formation consists of the Douglas Creek and Garden Gulch members and the kerogen-rich 


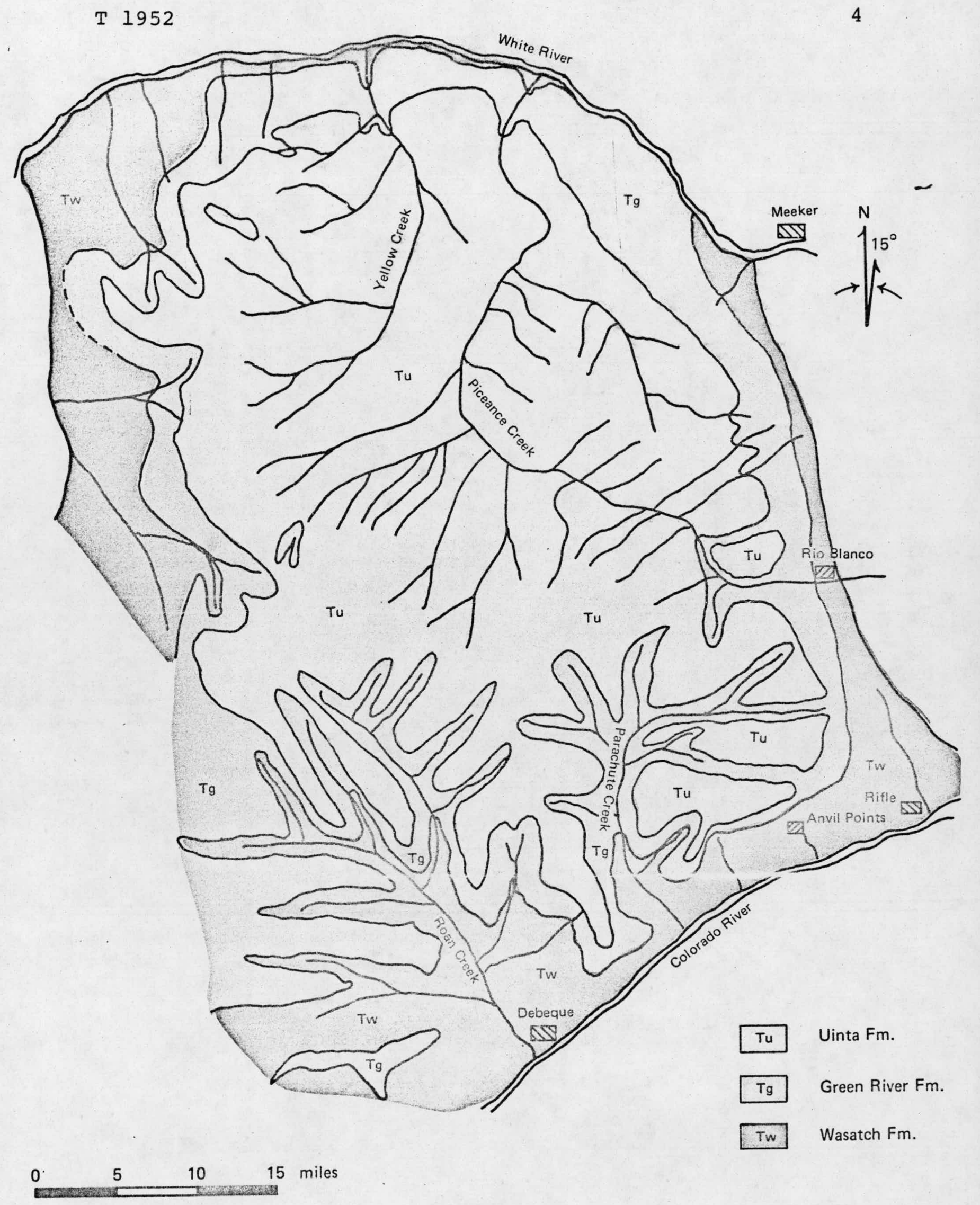

Figure 1. Simplified geological map of the study area. 


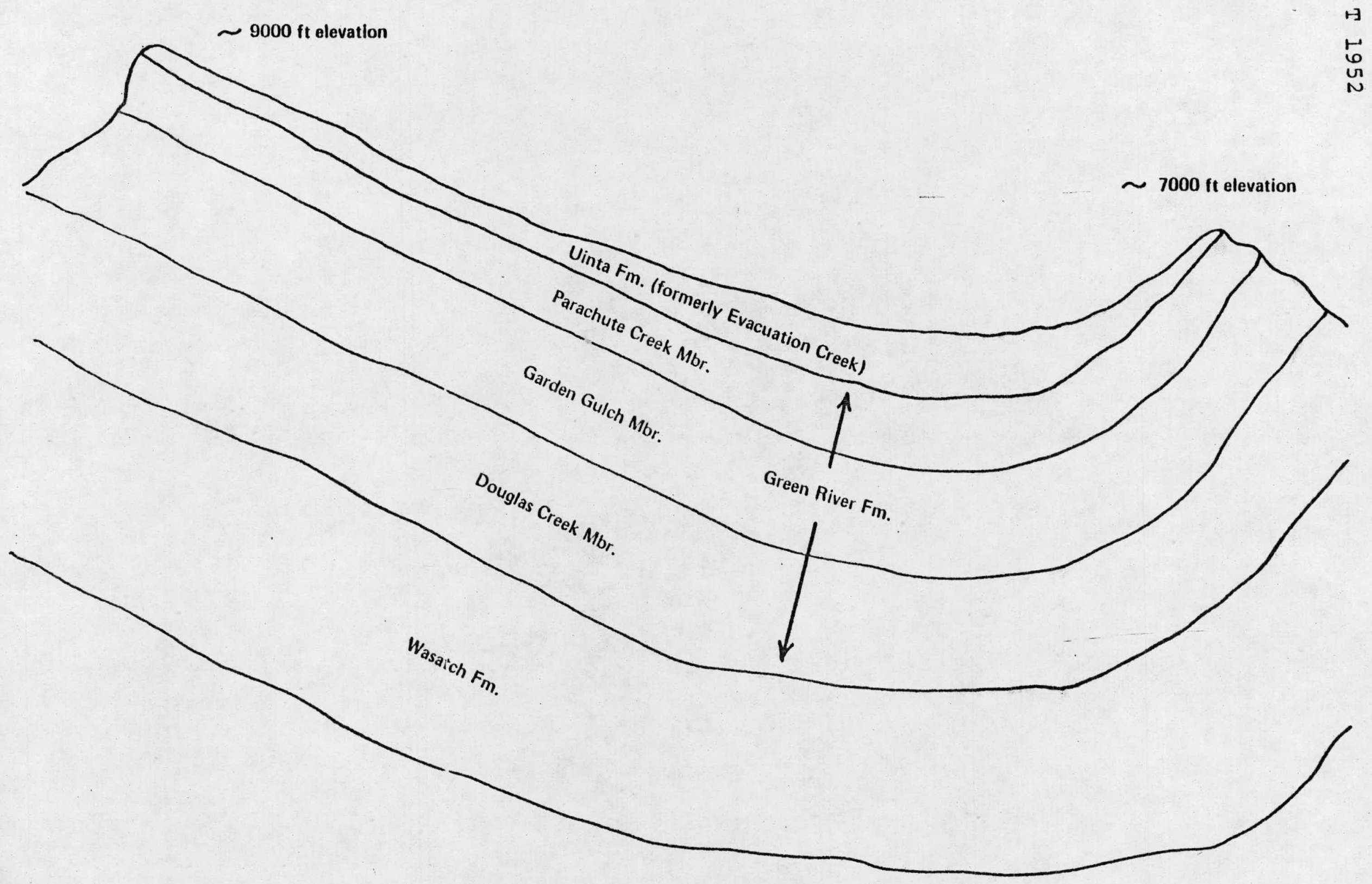

Figure 2. Cros:i section of stratigraphic section in Piceance Creel: basin. 
Parachute Creek member. In the vicinity of Rifle, the Douglas Creek and Garden Gulch members are named the Anvil Points member. Below the Green River formation lie the varicolored mudstone and siltstone of the Wasatch formation (Donnell, 1961). The ages of the formations referred to above are considered to be Eocene.

The streams in the interior of the basin dissect the Uinta formation. The heads of the streams flowing easterly or westerly cut into the upper portion of the Parachute Creek member. This moderate dissection contrasts with the extreme dissection of streams cutting lithologies in the Roan Creek and Parachute Creek areas. It was interesting to note that most streams are carving deep stream channels within gulches and valleys throughout the basin. In the early spring months the higher order streams are normally bank-full from snow melting in the high plateau area.

When this study began, there were no geochemical data directly pertaining to the soils or stream sediments of the basin. Thus the decision of what constituents to analyze had to be based upon previous studies emphasizing the oil shales of the Parachute Creek member. These studies (Smith, 1974) concluded that the oil shale had been deposited under extreme alkaline conditions. Thus it was decided to look at potentially toxic elements such as F, B, Mo, As, and Se which become mobile as anions under alkaline conditions. Analytical results (Table 1) of rock outcrop samples selected 
Table 1. X-ray fluorescence analysis of selected Piceance basin rock samples.

Crustal*

Abundance

Parachute Cr. $(n=8)$

(ppm) Min. Mean Max.

Mo $\quad 1.5$

3

As

I. 8
9

IT

33

2

4.7

$4 \sigma$

110

2

29

2

2

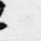

95

$\mathrm{zn} \quad 70$

0.05

$$
\text { Uinta }(n=5)
$$

Min. Mean Max.

2

3

6

5

10

21

2

2

3

39

*Krauskopf, 1967

mainly from the perimeter of the basin at the beginning of the study, indicated that some of these elements were elevated above crustal abundances, particularly in the parachute Creek member. Thus it appeared that this was a reasonable choice of constituents to study.

Since this work began, the regional geochemistry of the soil and stream sediments of the basin has slowly started to evolve. A recent soils study (Ringrose, et al., 1976) concluded that surface soil from ridge tops and valley bottoms is chemically similar and that Be, Cu, Ii and $\mathrm{zn}$ showed a marked increase from north to south. The first part of a stream sediment study (MCNeal, et al., 1976) concluded that nearly two-thirds of the elements analyzed exhibited significant differences between four streams (two from the Uinta Basin in Utah and two from the Piceance Craek Basin). The second part (McNeal, et al., 1976) concluded that Black 
Sulfur and Roan Creeks in the Piceance basin showed little variation between streams; most of the variation was associated with sampling scales of $1-10 \mathrm{~km}$ and 0-10 $\mathrm{m}$. 


\section{CHEMICAL ANALYSIS}

When work initially started on this thesis, the plan was to have the Project Central Analytical Facility at the University of Colorado analyze for B, As, F, Mo, and Se. Due to delays in funding, the PCAF analyzed the stream sediments only for Mo. Because the Chemistry-Geochemistry Department at Colorado School of Mines was not equipped to analyze for $B, F$, and $S e$, the analysis for $\mathrm{Cd}, \mathrm{Zn}, \mathrm{Hg}$ and $\mathrm{As}$ was done instead as elements of secondary interest. The $\mathrm{pH}$ and organic matter were also determined at CSM as originally planned. The analysis of As was discontinued after the processing of approximately 35 samples because of analytical problems. Cadmium, $\mathrm{Zn}, \mathrm{Hg}$, and As were all analyzed directly by atomic absorption, or by indirect methods in the case of Hg. The analytical procedure for each constituent is discussed in detail in Appendix A. 


\section{SAMPLE DESIGNS}

The sampling plan for determining which streams in the basin contain anomalous trace element concentraticis in their sediments was to select two $200 \mathrm{~g}$ samples 10 meters apart at the mouths (junctions) of most of the named streams in the basin (fig. 3). To keep the analytical load at a feasible level only one of the two samples was analyzed. If a sample was thought to be abnormally high, the other sample was to be analyzed to substantiate the first high value.

The sampling design used to describe the background variation of the five major streams is considerably more complicated than the design for detecting anomalous creeks. As previously discussed, the objective is to try to describe as much of the geographic variability as possible. Once the variability is known, further sampling designs can be made to determine practical baselines for the area.

For the purpose of this study, a baseline is defined to be a reference that not only describes the mean and limits of concentration inherent in nature, but also accounts for the geographical scale of variability. The most effective way of expressing a baseline is with a geochemical map. But if the variability is local, it would require too many samples to develop a stable or reproducible geochemical map, thus an expected range would be the appropriate manner of expressing 

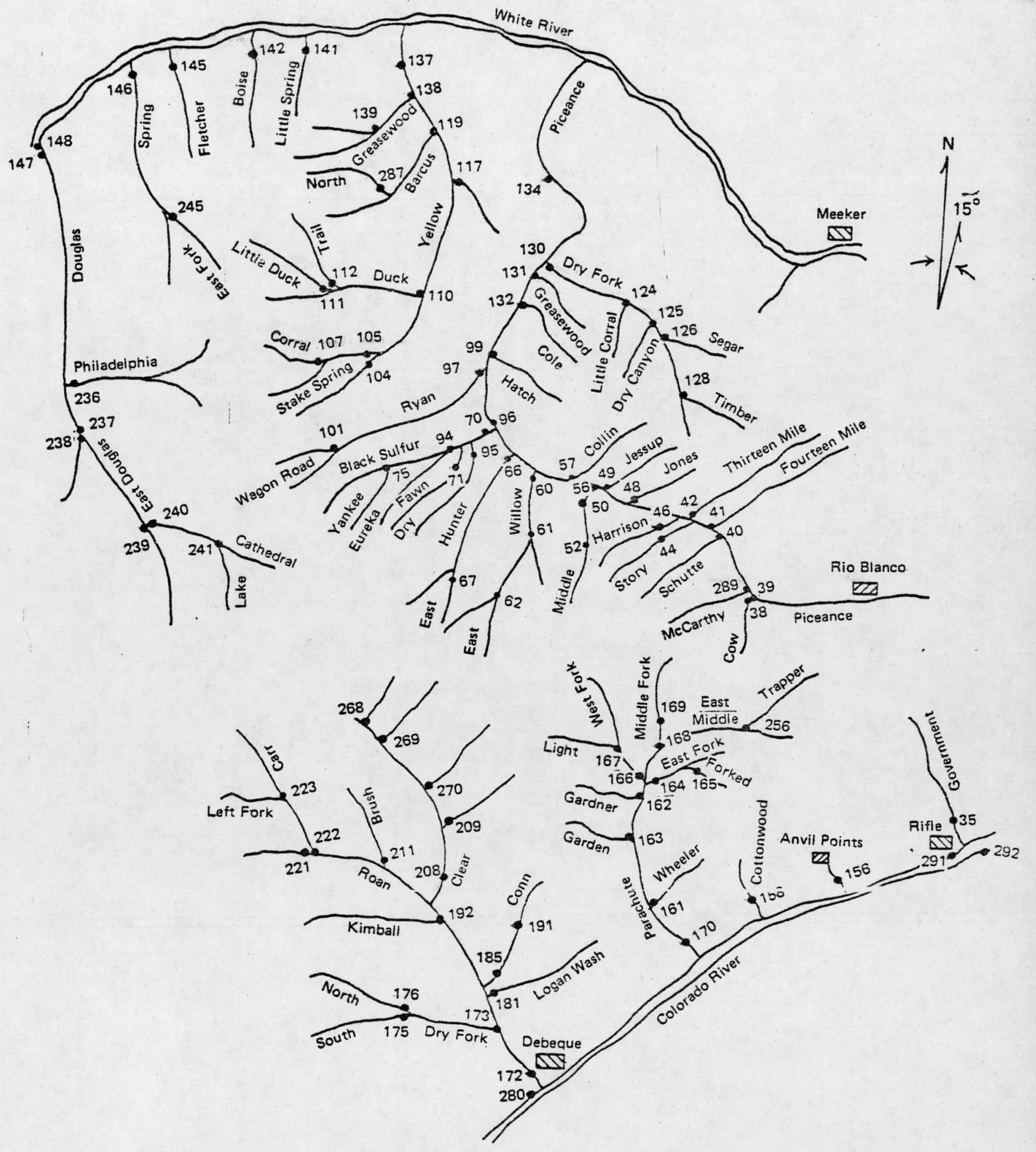
the baseline.

To obtain an estimate of natural variability in the five major streams, a hierarchial or nested sampling design was used. The U.S.G.S. (Miesch, et aI., 1976a, p. 45) has made extensive use of this type of sampling because of its efficiency in describing geochemical variability on a regional basis. The dashed lines across the streams in Figure 4 show the predefined limits of this type of sampling for each stream. The dashed boxes indicate the length of channel expressed by the nested sampling on each stream. The position of each of the nested sampling groups was chosen at random. The detailed breakdown of each of the nested sampling groups is shown in Figure 5 or expressed in another manner by Figure 6.

Figure 5 illustrates the various sampling factors $(2 \mathrm{~km}$, $200 \mathrm{~m}, 20 \mathrm{~m}$, and samples) which partition the total variance. Briefly, two $2-\mathrm{km}$ segments were chosen $10 \mathrm{~km}$ apart. Within each of these $2-\mathrm{km}$ segments, two 200 meter segments were chosen at random, one within each $1 \mathrm{~km}$ segment. Then within each 200 meter segment, two 20 meter segments were chosen at random, one within each 100 meter segment. And finally within each 20 meter segment, 2 samples were chosen, one within each 10 meter segment. 
T 1952
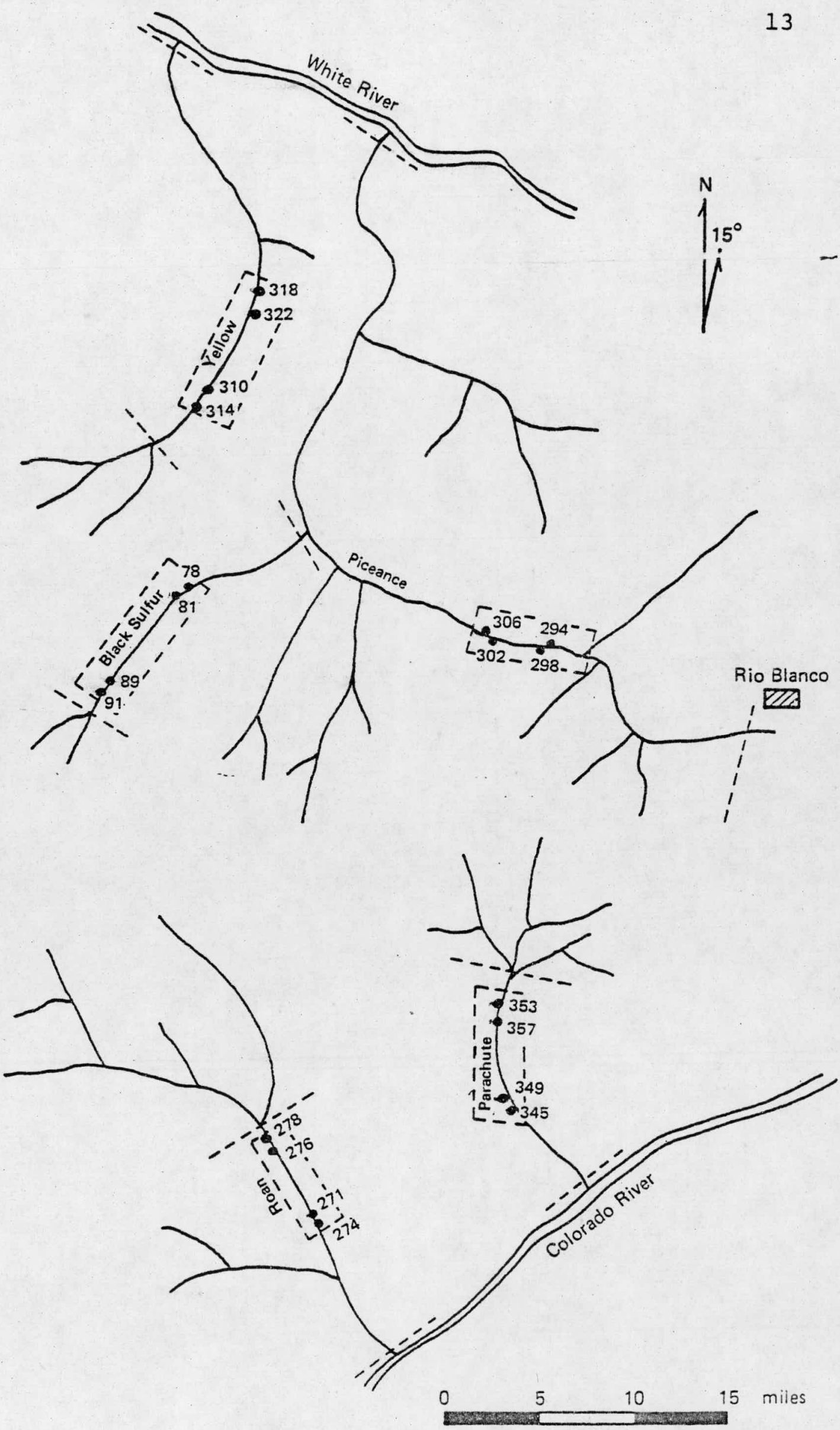

Figure 4. Boundaries of the nested model. 


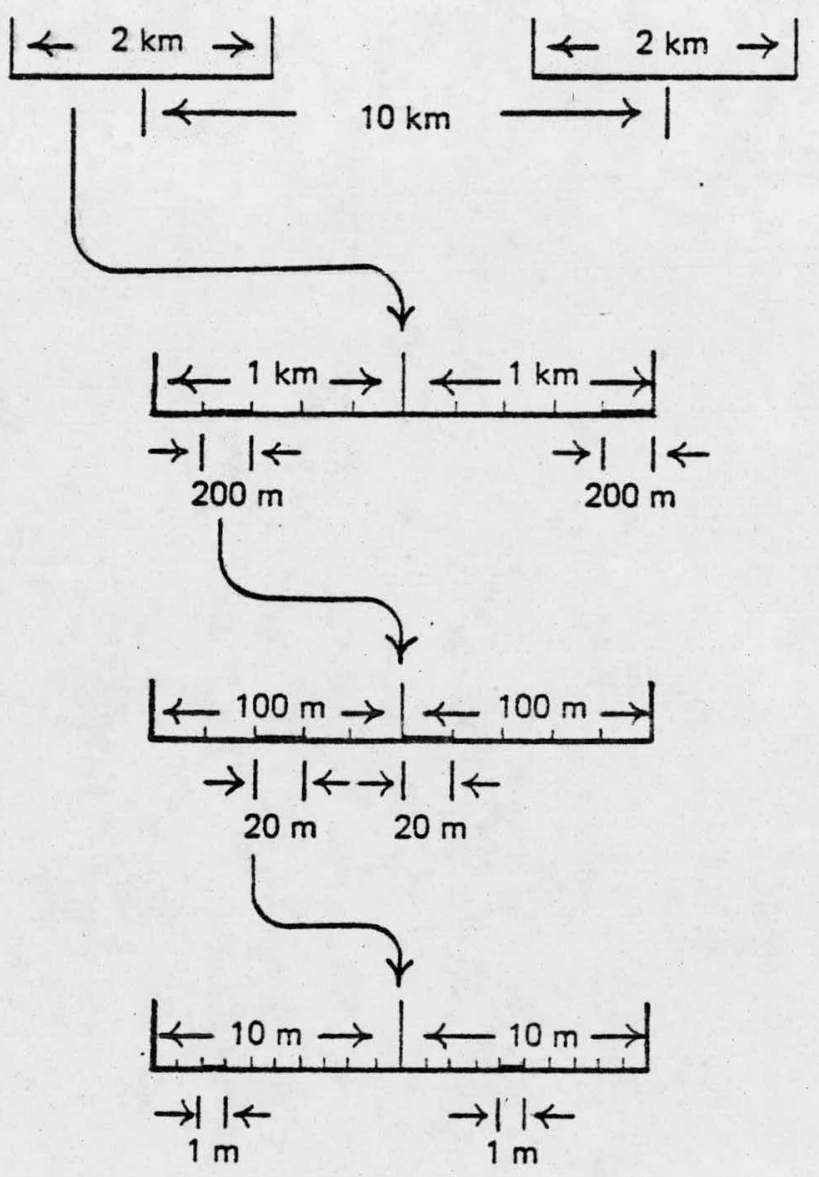

Figure 5. Detailed breakdown of nested sample design. 


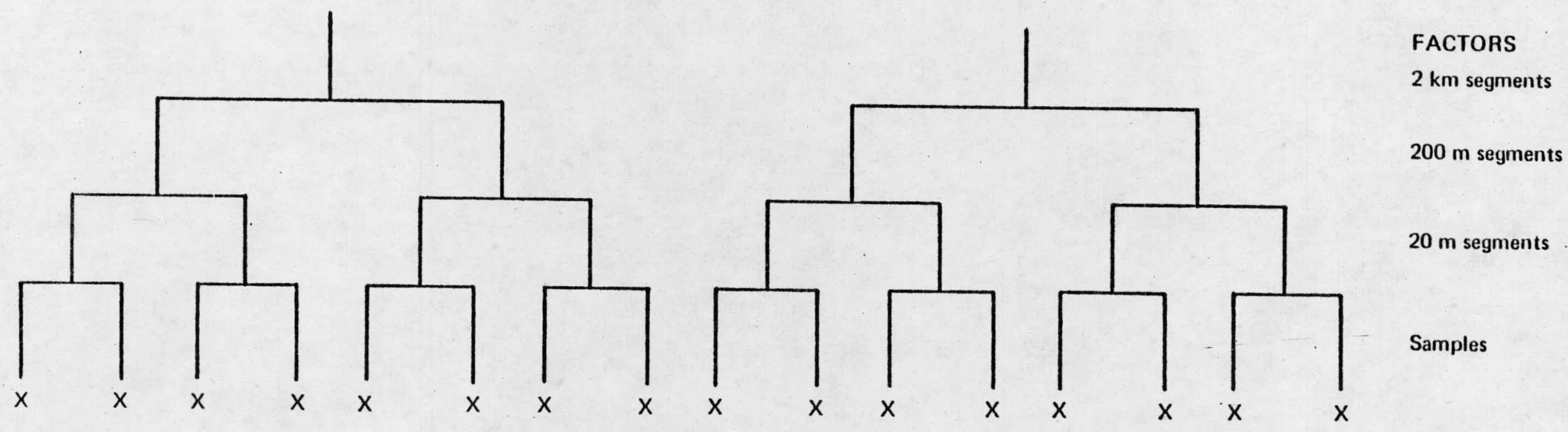

Figure 6. Diagran of nested model for each individual stream. 


\section{INTERPRETATION OF NESTED SAMPLE DESIGN}

Definition of Models and Variables

The same definition of sampling locality will apply here as defined in various papers by Miesch $(1976,0.3)$. For the design as shown in Fig. 6 , there are four factors -- $2 \mathrm{~km}$ segments, $200 \mathrm{~m}$ segments, $20 \mathrm{~m}$ segments, and samples. Two $200 \mathrm{~m} \mathrm{seg-}$ ments were chosen at random within each $1 \mathrm{~km}$ segment of the $2 \mathrm{~km}$ segments. This choice was made as a way of assuring that the average distance between segments would be $1 \mathrm{~km}$. The other factors were done in like manner so that the average distances between $20 \mathrm{~m}$ segments and samples would be $100 \mathrm{~m}$ and $10 \mathrm{~m}$, respectively.

The model used for this design is

$$
x_{i j k l m}=\mu+\alpha_{i}+\beta_{i j}+\gamma_{i j k}+\delta_{i j k l}+\varepsilon_{i j k l m},
$$

where $\alpha$ represents the localities ( $2 \mathrm{~km}$ segments), $\beta, \gamma$ and $\delta$ represent sublocalities $(200 \mathrm{~m}$ segments, $20 \mathrm{~m}$ segments, samples), and $\varepsilon$ represents the analysis. More specifically, $\mathrm{x}_{i j k l m}$ represents the $\mathrm{m}^{\text {th }}$ analytical determination on the $1^{\text {th }}$ sample from the $k^{\text {th }}$ sublocality of the $j^{\text {th }}$ sublocality of the $i^{\text {th }}$ locality. $\alpha_{i}$ is the difference between the grand mean and the mean for the $i^{\text {th }}$ locality; $\beta_{i j}$ is the difference between the mean of $j^{\text {th }}$ sublocality taken from the $i^{\text {th }}$ locality and the mean for the $i^{\text {th }}$ locality $\left(\mu+\alpha_{i}\right)$. The rest of variables are defined in a similar manner. The total variance among the analytical determinations will be separated 
into the following components:

$$
\sigma_{x}^{2}=\sigma_{\alpha}^{2}+\sigma_{\beta}^{2}+\sigma_{\gamma}^{2}+\sigma_{\delta}^{2}+\sigma_{\varepsilon}^{2} .
$$

The nested model will estimate these components as

$$
s_{x}^{2}=s_{\alpha}^{2}+s_{\beta}^{2}+s_{\gamma}^{2}+s_{\delta}^{2}+s_{\varepsilon}^{2} .
$$

Although the frequency distribution of the data was not examined, a $\log$ to the base 10 transformation of the data was made. It is well known that trace element distributions in natural systems are generally lognormal. Since the U.S.G.S. has taken this approach, any comparisons of results from this study and their studies are more likely to be meaningful. Also, assuming that the samples did come from a lognormal distribution, the likelihood of variable bias will have been reduced and tests for the significance of the five variance components will be more valid by making the transformation.

The interpretation of the variance components is explained in various papers (Miesch, 1976b, Krumbein, et al., 1956). As previously stated, the sampling was designed such that the average distance between samples was $10 \mathrm{~m}$, the average distance between $20 \mathrm{~m}$ segments was $100 \mathrm{~m}$, etc. Thus, the variance component $\mathrm{s}_{\delta}^{2}$ is taken as a measure of all variation in the stream channel that is on a scale of $10 \mathrm{~m}$ or less. Following the same reasoning $s_{Y}^{2}$, the next variance component, is taken to represent the natural variance from $10 \mathrm{~m}$ to $100 \mathrm{~m}$. The other variance components are defined in like manner and are listed in Table 2. 
Table 2. Geographic scales of variance components.

$\begin{array}{lc}s_{\delta}^{2} & 0-10 \mathrm{~m} \\ s_{\gamma}^{2} & 10-100 \mathrm{~m} \\ s_{B}^{2} & 100 \mathrm{~m}-1 \mathrm{~km} \\ s_{\alpha}^{2} & 1-10 \mathrm{~km} \\ s_{B}^{2} & \begin{array}{l}\text { variance between the five } \\ \text { selected streams }\end{array}\end{array}$

If a comparison is made between streams, a new component of variance $\left(B_{i}\right)$ is created in the model:

$$
\begin{aligned}
x_{i j k l m n} & =\mu+B_{i}+\alpha_{i j}+\beta_{i j k}+\gamma_{i j k I}+\delta_{i j k l m} \\
& +\varepsilon_{i j k l m n}
\end{aligned}
$$

The estimate of the variance between streams, $s_{B}^{2}$, would be interpreted as representing just the variance between the five selected streams. The variance due to processing and analyzing the samples (Miesch, $1976 b$ ) is $s_{\varepsilon}^{2}$.

Interpretation of the Nested Samples

The analysis of variance of the nested design for the major streams in the Piceance basin is summarized in Table 3 . The part of the table listed as "Analysis of Logarithmic Variance" indicates that all data were transformed to log base 10 before computing the analysis of variance (Keith, et al., 1974). Under "Sumary Statistics," the geometric mean is used to estimate the most typical concentration of a theoretically assumed log normal distribution (Miesch, 1976b, p. 21). The geometric deviation is a convenient way of 
Table 3. Geochemical summaries for stream sediments of major creeks in Piceance basin (data given in parts per million; an asterisk (*) indicates variance component is significantly different from zero at the .05 probability leve1).

Analysis of Logarithmic Variance

\begin{tabular}{ccc}
\hline & \multicolumn{1}{c}{ Percent of Total Vartance } & Ana1yt- \\
Total & 1cal \\
Log 10 & $\begin{array}{c}\text { Between } \\
\text { Vartance }\end{array}$ & Streams $1-10 \mathrm{Km}$ \\
\hline
\end{tabular}

Summary Statistics

Element Stream Vartance Streams 1-10Km $100 \mathrm{~m}-1 \mathrm{Km} 10 \mathrm{~m}-100 \mathrm{~m}$ 0-10m Error ${ }^{1}$ tric Geometric Geometric Expected

Mo

A11

Roan

.0552

$73 *$

Black Sulfur

Piceance

Parachute

.0159

$-$

.0365

Yellow

.0143

$$
\begin{array}{rr}
-\quad 15 \\
-\quad 0
\end{array}
$$

.0044

.0215

Zn

A11

Roan

.0066

Black Sulfur

$$
.0134
$$

Piceance

.0030

Parachute

.0011

Yellow

.0012

.0036

Hg

A11

Roan

.0614

Black Sulfur

Piceance

.0162

.0214

Parachute $\quad .0333$

Yellow $\quad 0085$

Organic A11

Roan

.1831

Black Sulfur

Piceance

.0835

Parachute

.1416

Yellow

.0198

.0011

.0326

$-\quad 38$
$-\quad 3$

36

$$
\text { - }
$$

$-$

46
$-\quad 0$

- 14

- 30

$66 *$

-

38

$-\quad 11$

$-$

$-$

$69 *$

$12 *$
$-\quad 20$

- 50

- 60

-
$-\quad 17$

-

$\begin{array}{rlr}3 & 17 & 6 \\ 0 & 87 & - \\ 0 & 76 & 8 \\ 21 & 79 & - \\ 0 & 91 & - \\ 4 & 58 & - \\ 3 & 33 * & 7 \\ 0 & 47 & 17 \\ 10 & 37 * & 4 \\ 9 & 91 * & 0 \\ 37 & 40 & 9 \\ 9 & 48 & 14 \\ 0 & 20 * & 8 \\ 0 & 80 * & 9 \\ 13 & 43 * & 6 \\ 23 & 54 * & 12 \\ 0 & 61 * & 33 \\ 26 & 0 & 73 \\ 0 & 16 * & 0 \\ 4 & 70 * & 0 \\ 0 & 39 * & 0 \\ 0 & 30 & - \\ 12 & 22 & 5 \\ 0 & 76 & 1\end{array}$

Mean
Deviation Error 95\% Range

$\begin{array}{llll}4.2 & 1.64 & 1.09 & 1.6-11.1 \\ 3.5 & 1.28 & - & 2.1-5.7 \\ 2.9 & 1.41 & 1.09 & 1.5-5.6 \\ 4.2 & 1.33 & - & 2.4-7.4 \\ 9.5 & 1.14 & - & 7.3-12.3 \\ 3.3 & 1.34 & - & 1.8-5.9\end{array}$

$61.0 \quad 1.20$

$63.8 \quad 1.28$

$1.03 \quad 28.6-129.9$

$53.3 \quad 1.12$

67.8

68.9

1.08

1.08

39. $9-102.0$

$1.01 \quad 42.5-66.9$

$1.00 \quad 58.1-79.1$

$52.5 \quad 1.13$

1.02

61.3-77.4

$.29 \quad 1.67$

$.58 \quad 1.27$

1.04

41.7-66. 2

.36

1.44

1.12

1.07

$.11-.78$

1.08

$.37-.92$

.23

1.35

1.09

1.19

1.14

$.13-.41$

$.28 \quad 1.39$

$.91 \quad 2.47$

1.26

2.47
1.87

1.00

1.00

.79
1.02

1.00

2.54

1.07

.24

1.46

$\overline{1} .00$

1.00

$.16-.49$

$.12-.19$

$.15-5.55$

$.36-4.41$

$.20-3.19$

.60-1. 72

2. $22-2.91$

$.11-.51$

\footnotetext{
${ }^{1}$ Where - appears, the analytical component is included in the 0-10m component.
} 
expressing the total logarithmic variance in terms of ppm or percent. The geometric error is that part of the geometric deviation which is due to analytical error (Miesch, 1976a, p. 30A). The expected range which is calculated (Appendi: B, p. 50) from the geometric mean and deviation is interpreted as a range estimated to contain $95 \%$ of the assumed lognomal population (Miesch, 1976b, p. 31). The all-stream results are derived from the nested model defined in equation (4). The results of the individual streams were derived from equation (1). The test for significance of all the variance component values are shown in the analysis of variance tables (Appendix B, p. 94 ).

From Table 3, two variance components stand out: the variance from 0-10 $\mathrm{m}$ for the individual streams, and the stream variance component for the all-stream data. The significance from $0-10 \mathrm{~m}$ for Mo cannot be tested because the 0-10 $\mathrm{m}$ scale of variance and the analytical variance are combined in the lowest scale factor. The small analytical variance of the Black Sulfur Creek indicates that most of the variance in this lowest scale factor is due to $0-10 \mathrm{~m}$ geographic variance. Thus the $0-10 \mathrm{~m}$ factor probably will be significant if a test could be made for it. In general, the consistency of the significance at the $0-10 \mathrm{~m}$ scale may be a reflection of the power (degrees of freedom) of the sample design being concentrated at the lower levels (Leone, et al, 1968). Except for $\mathrm{Zn}$, there are significant differences 
between streams for all the constituents. A similar study (McNeal, et al., 1976) done in the same area and in Utah also brought out the significant differences between streams for many other elements.

The purpose of the nested sample design is to provide information for future baseline investigations. However, where results can justify it, preliminary baselines are usually attempted from reconnaissance studies such as this. Since the nested results show that most of the variance is at the 0-10 m scale for individual streams, it would appear that an expected range could be used as a preliminary baseline for each of the constituents within each of the streams. Further random sampling at any interval may increase ones confidence in the expected range but future sampling for the purpose of developing geochemical maps seems to be economically unfeasible for most elements. To develop stable maps which will describe a reasonable percentage of the background variance of each individual stream would require sampling localities closer than 10 meters apart. The cumulative variance curve shown in Figure 7 illustrates this very clearly. The diagram shows that sampling at infinitely small intervals, approximately $100 \%$ of the geochemical variance would be expressed. Sampling at $10 \mathrm{~m}$ intervals, approximately $40 \%$ of the variance could be expressed; at intervals of $1 \mathrm{~km}$ only $10 \%$ of the variance could be shown. Thus, it seems that even if it were economically feasible to 


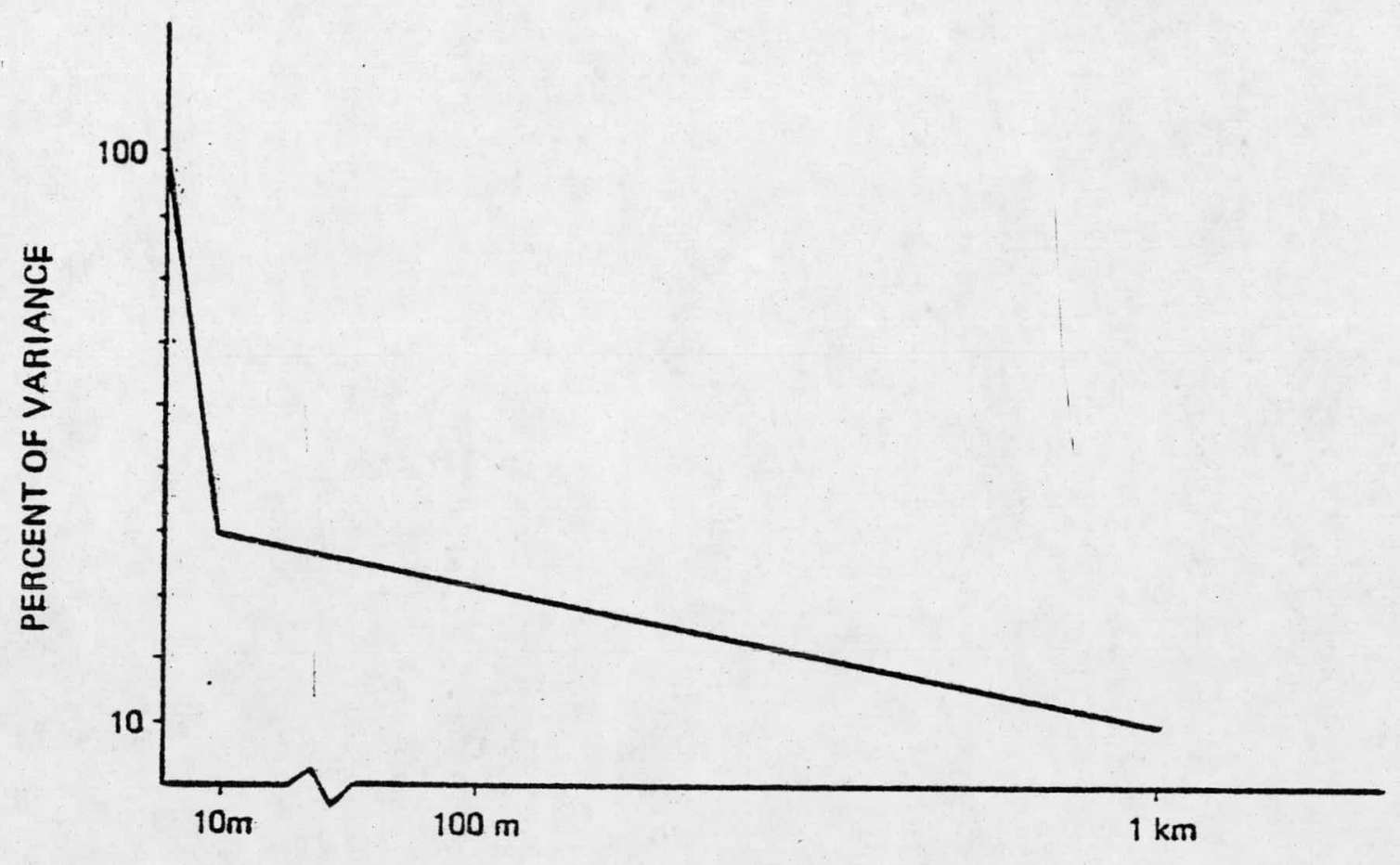

DISTANCE (not to scale)

Figure 7. Typical cumulative variance curve for streams with large percent of variance at low scale.

sample at intervals $10 \mathrm{~m}$ apart, it will not be satisfactory because only $40 \%$ of the total variance could be expressed.

The following discussion will illustrate how the nested results of the all-stream data might be interpreted in planning new sampling designs for future baselines. If one were interested in characterizing the Piceance Creek Basin as a whole, it might seem reasonable, for Mo, Ig and organic matter, to choose streams as localities because the stream component variance is much larger than any of the other components. One could conclude that one sample taken within these localities would provide enough information to make a stable geochemical map that would express a large percent of 
the total variation. For example, using the estimated variance components for Mo (see Appendix B for calculations), it would take one sample per stream (locality) and one analysis of that sample to provide a variance mean ratio (Miesch, 1976b, p. 101) large enough to predict a stable map. The analysis of variance results predict $\mathrm{Hg}$ and organic matter could be treated in a similar manner.

A different interpretation would apply to $\mathrm{zn}$. The allstream data (Table 3 ) shows $\mathrm{zn}$ to be much more heterogeneous at the lower geographic scales than the other constituents. The fact that there is only significance at $0-10 \mathrm{~m}$ scale and possibly at 10-100 m scales suggests that a regional geochemical map of the area may not be feasible and that an expected range may have to be used as a baseline to characterize the element for the basin. This is dissimilar to the nature of $\mathrm{zn}$ in surface soils which has a regional trend from north to south (Ringrose, et al., 1976).

In actuality, the above sampling plan for Mo, $\mathrm{Hg}$, and organic matter will probably not express what is indicated from the all-stream nested results. The problem lies with the interpretation of the stream variance component $\left(B_{i}\right)$. It should be recalled that the streams were not picked at random throughout the basin. This makes $B_{i}$ a parametric factor rather than a random factor in the nested model (4). Therefore, the significance of this factor is that it represents a measure of the non-homogeneity of the stream mean 
values rather than a measure of the variance of some random component. In other words, the contrast between streams throughout the basin is probably not as sharp as this factor might lead one to believe. It may be more logical to inter- pret the stream variance component as expressing the contrast between the major drainage systems of the basin (Roan, Parachute, Piceance, and Yellow) since the nested samples were taken from the main channel of these systems.

Because the stream variance component percentage was so high, it was thought relevant to determine which stream or streams were contributing most to the high contrast. The results of the test for the significant grouping among stream means are shown in Table 4 for $\mathrm{Zn}$, Mo, $\mathrm{Hg}$, and organic matter. Duncan's Multiple Range Test (Miesch, 1976a, p. A3I) was used for the testing of significance of differences among these means.

The result of the above test on the $\mathrm{zn}$ stream means seemed to support the low stream variance component percentage of $\mathrm{Zn}$ in the nested sampling. From Table 4, this is seen by the lack of distinct grouping of streams. For $\mathrm{zn}$, either group of means underlined is interpreted to indicate that there is no significant difference between those means underlined at the $95 \%$ confidence level. The overlapping indicates that there is more than one way in which significant groups can be classified. Thus, in the case of $\mathrm{zn}$, there is either a significant difference between the group $\bar{x}_{Y} \bar{x}_{B} \bar{x}_{R} \bar{x}_{P}$ 
Table 4. Stream mean groupings for $\mathrm{zn}$, Mo, Hg and organic matter.

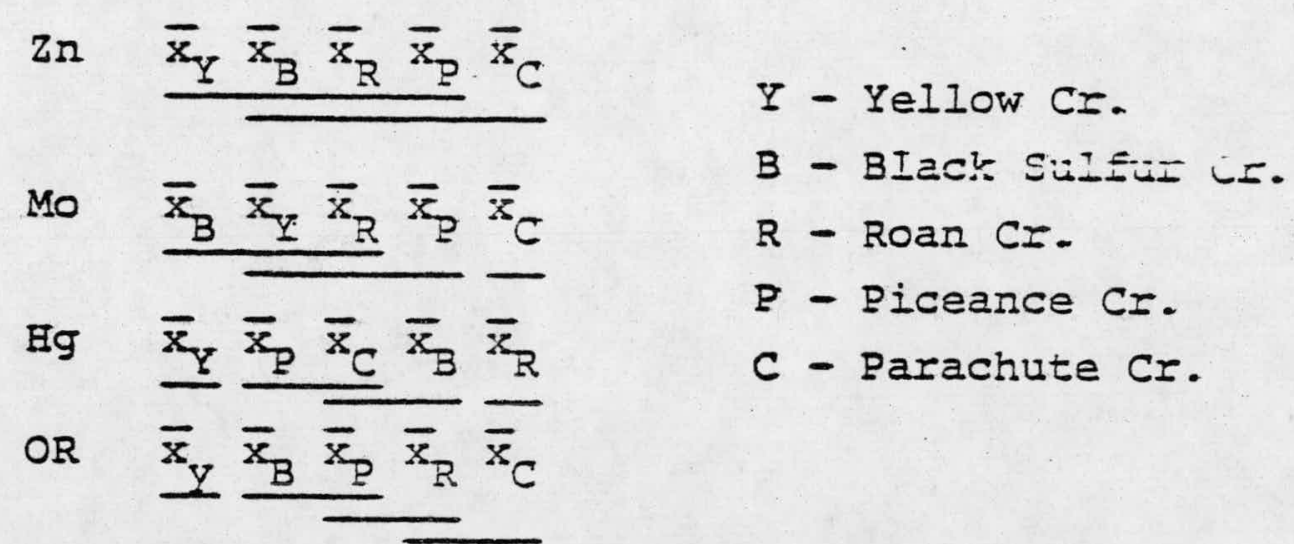

and the single mean group consisting of $\bar{x}_{C}$ or there is significant difference between the group $\bar{x}_{C} \bar{x}_{P} \bar{x}_{R} \bar{x}_{B}$ and $\bar{x}_{Y}$. In the case of Mo, it may be that the significant difference between $\bar{x}_{C}$ and the rest of the stream means is the cause of the high stream component variance. For Hg or organic matter there is no strong indication of one stream or two groups dominating the results, though $\bar{x}_{Y}$ does stand out somewhat for organic matter.

Another approach could have been taken to examine which stream or streams may have been affecting the stream variance component. First, the stream variance component would be computed with just two streams making up the stream factor Ievels. Then another stream would be added and the stream variance component would be calculated again. BY repeating this procedure until all five streams have been added to the model and by comparing the change in the stream variance component, one may determine which stream or streams 
were influencing the stream factor. Before taking this approach it may be desirable to use the multiple range test first to determine the order of adding levels to the stream factor. The main reason for using this method is that cne multiple range test may be too conservative; the only apparent disadvantage is that this approach may take a considerable amount of computer time.

From the above discussion, one is left with the question of how the sampling might be done if it were important to describe the basin as a whole. To answer this question properly, it is thought that another survey will have to be done using a nested sampling design which will define the tributaries of the six major streams in the basin--Yellow, Piceance, Roan, Parachute, Clear, and Dry Fork (Piceance) as its master localities. The other factors will possibly be $200 \mathrm{~m}$ segments, $20 \mathrm{~m}$ segments, samples, and replications. In this case, the factor "streams (tributaries)" will be a random component instead of parametric as before. If a staggered, nested analysis of variance design (Leone, et al., 1968) were used and if composite samples were taken, only three samples per stream will be required. The staggered, nested design will reduce the number of samples that must be collected, and it will distribute the degrees of freedom more evenly throughout the factors (Miesch, 1976a, p. A30). From the analysis of variance tables (Appendix B, p. 94) it will be noted that the degrees of freedom increase from the 
$2 \mathrm{~km}$ segments factor or the stream factor to the sample factor in all cases. This tends to give more significance to the factor with the highest degree of freedom. Collecting composite samples will reduce the analytical load. 


\section{INTERPRETATION OF THE STREAM JUNCTION DESIGN}

The model for this sampling approach is

$$
x_{i j}=\mu+\alpha_{i}+\varepsilon_{i j} .
$$

$x_{i j}$ represents the $j$ th analytical determination in the $i t h$ locality (stream junction). $\alpha_{i}$ is the difference between the grand mean and the mean for the ith locality, and $\varepsilon_{i j}$ is the analytical error for the laboratory determination on the ith locality. Compared to equations ( 1 ) and (4), this is indeed a simpler design. It should be kept in mind that the objective of the stream junction sample design is not to describe as much of the geochemical variability as possible, but to determine whether any streams have sediments with unusually high concentrations of any of the constituents under consideration (As, Cd, Mo, $\mathrm{Hg}$, and $\mathrm{Zn}$ ).

When locality is used in the discussion of stream junction sampling, it will represent the stream channel above the junction. It is thought that random sampling within a locality (stream) will not express an anomalous locality as effectively as will sampling on the downstream end of the locality. Of course, this assumption is dependent on the nature of the dispersion train from the anomalous source. If, for example, an anomalous source is located at the head of a typical sampled stream, a halo of 10 miles or longer may be required for detection at the mouth of the stream. Thus only strong anomalies or relatively large size targets will be detected by this sample design. 
Table 5. lists the results of the analysis of the approximately 100 samples taken at stream junctions throughout the basin. Only 35 of the samples were analyzed for As. In establishing whether any of the samples reflect creek sediments with abnormally high concentrations, the following factors are considered from the table. The geometric means for $\mathrm{Cd}, \mathrm{As}, \mathrm{Hg}$, and Mo seem to express concentrations that are typically found in shales. From abundance tables (Krauskopf, 1967), it seems that on the average, trace element concentrations in shales are higher than for other types of rocks. The expected range values are expressing estimated concentration ranges for $95 \%$ of the stream localities. Nearly all listed values in the 5 highest ranked columns lie within the $95 \%$ estimated ranges. The values that are not within the ranges do not appear to be conspicuously different. Thus it is concluded, without any statistical tests, that values expressing the element concentration of stream localities are within $95 \%$ limits. Since only one sample was taken per stream, it cannot be said how much of the variances between stream locality values are due to variance within stream localities. If composite sampling had been done within the stream localities ( 6 or 7 samples mixed together into one sample bag) the variance within streams could have been estimated without adding to the analytical load. 
abundant in Mo and As, and the $\mathrm{pH}$ of sediments is quite alkaline. Mo and As can be very mobile under high pH conditions, and therefore can be considered available to plants. With a deficiency of Cu, it takes only 10 to $12 \mathrm{ppm}$ of Mo in forage to be toxic for cattle and sheep (Gough, et al., 1976, p. 24).

One may question whether or not sampling the major channel of a drainage system would be comparable to sampling the tributaries draining into it. A comparison between the expected ranges of the stream junctions and nested samples in Table 6 show that, with few exceptions, the nested expected ranges are smaller. Although the analytical error is removed from the nested ranges, these errors are too small to account for the differences.

It may be that there is a significantly higher scale variance than the upper scale limit (1-10 km) of the nested model. This explanation for the difference in the nested and stream junction expected ranges could also explain the bimodal and trimodal distributions of Mo and $z n$ (igurs=? and 9) in the stream junction samples of the Piceance Creek drainage. If each of these distributions is separated into subsets reflecting the bimodal or trimodal character of each and then plotted on a map with different symbols indicating the high, medium, and low concentration subsets, a conceivably higher scale trend can be seen (Figs. 10 and 11). At the east end of Piceance creek high values group together for $\mathrm{zn}$ and low values group together for Mo. Note that this 
Table 6. Comparison between stream junction and nested expected ranges for individual streams.

Mo

Piceance

Roan

Parachute

Yellow

Zn

$\begin{array}{lllll}\text { Piceance } & 53.8 & 1.22 & 36 . I-80.1 & 58.1-79.1 \\ \text { Roan } & 66.4 & 1.34 & 37.0-119 & 39.9-102.0 \\ \text { Parachute } & 64.8 & 1.16 & 48.2-87.2 & 61.3-77.4 \\ \text { YeIlow } & 53.7 & I .20 & 37.3-77.3 & 41.7-66.2\end{array}$

Eg

Piceance

Roan

Parachute

Yellow

organic carbon

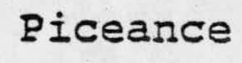

Roan

Parachute

YeIIow
Stream Junction

(pMm)

GD

2.8

2.72

5.6

1.56

1.55

1.42

6.7

Expected Range* (ppm)

Nested

Expected Range*

(ppm)
$2.4-7.4$

$2.3-13.6$

$2.3-13.2$

$3.3-13.5$
$2.1-5.7$

$7.3-12.3$

$1.8-5.9$
$.3-20.6$

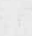




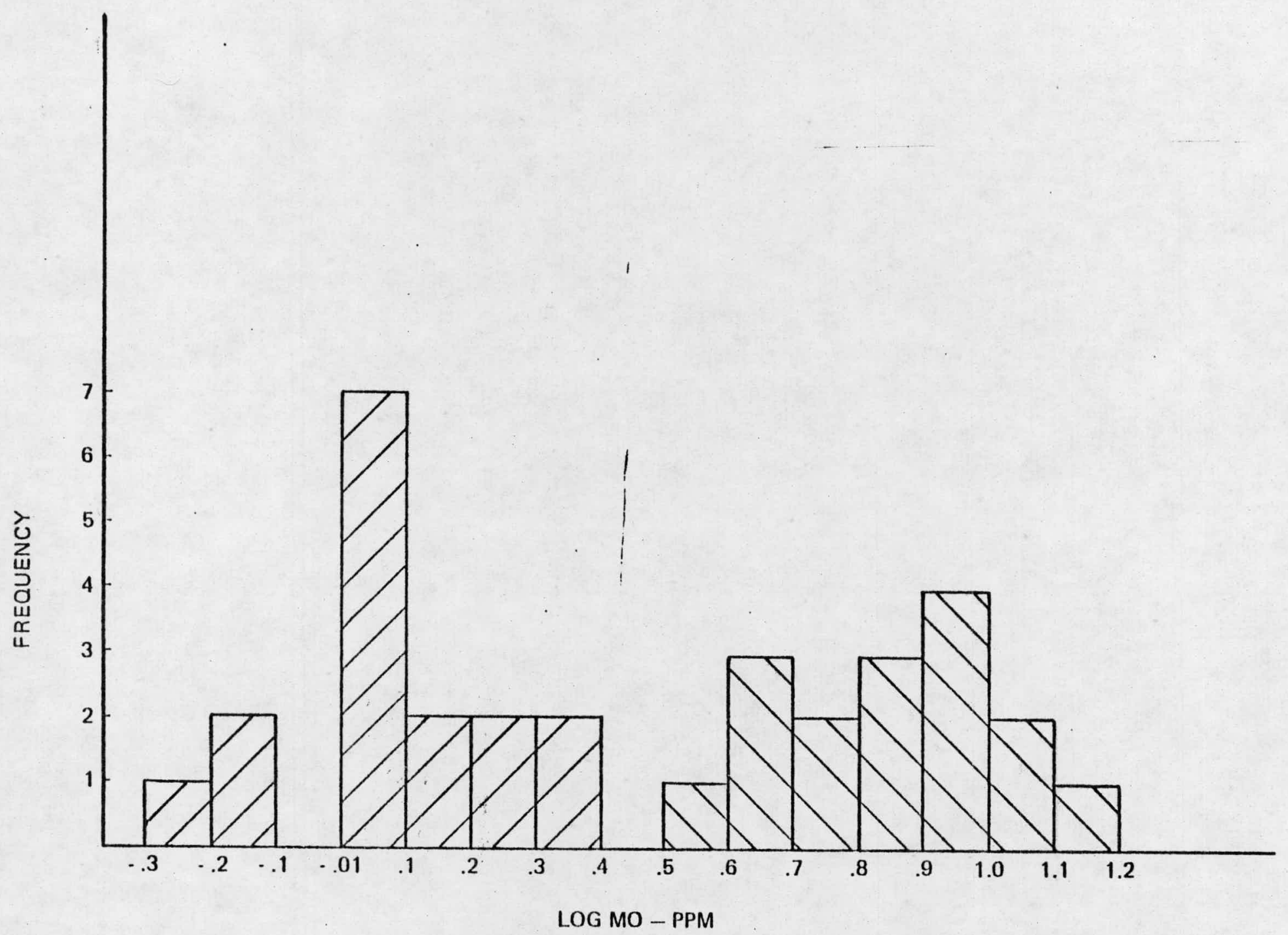

Figure 8. Histogram for Mo in Piceance Creek. 


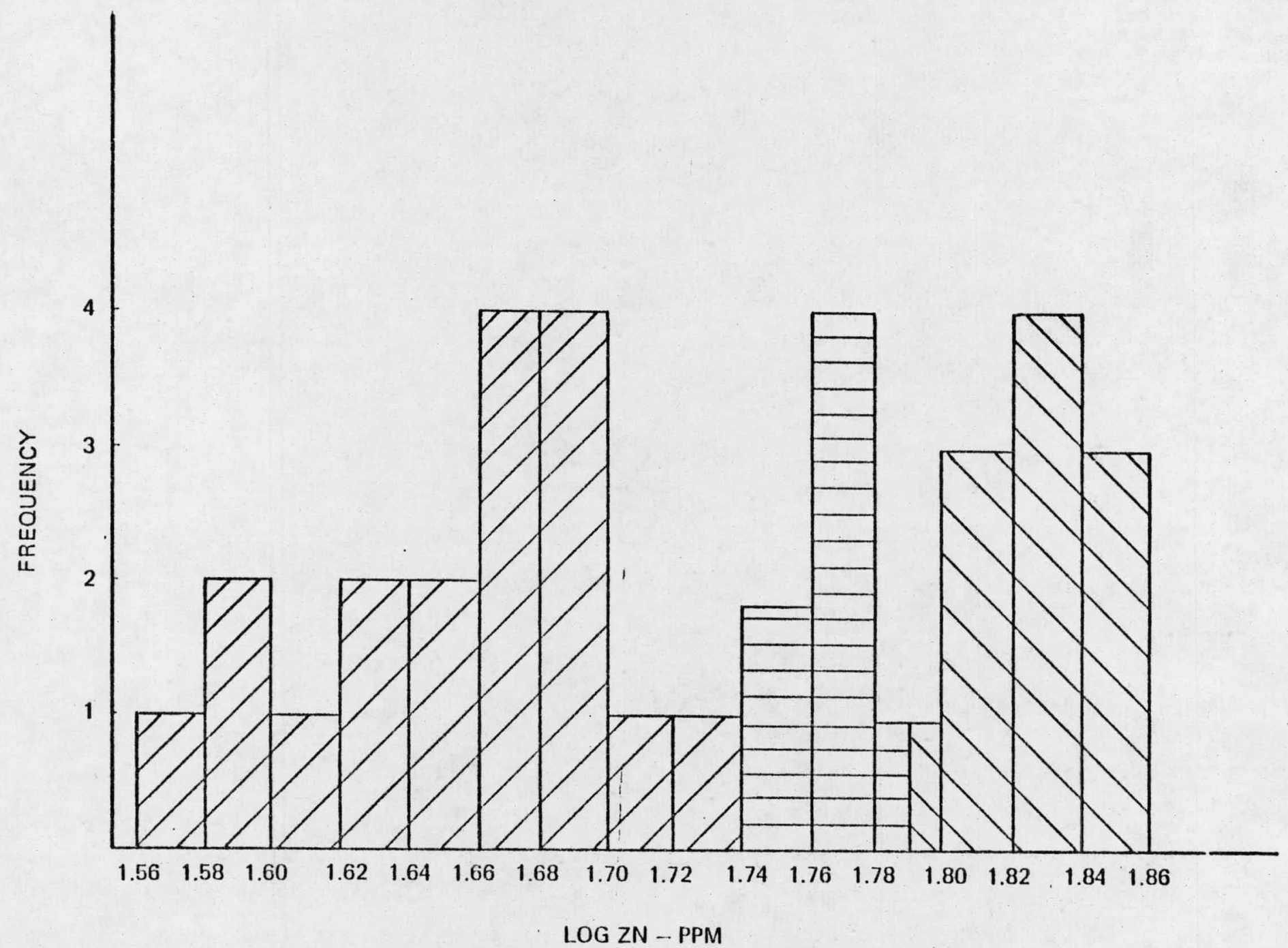

它 

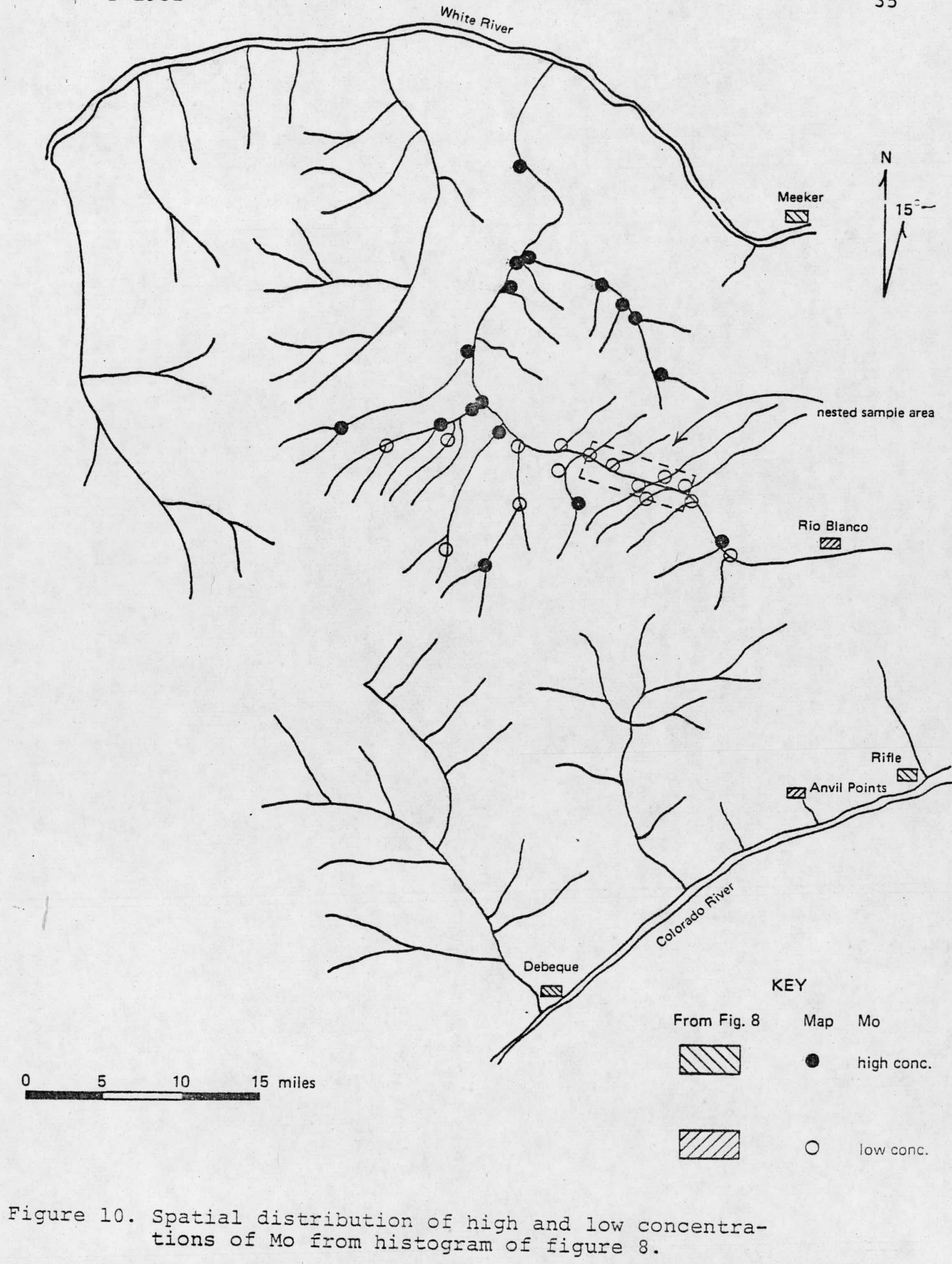

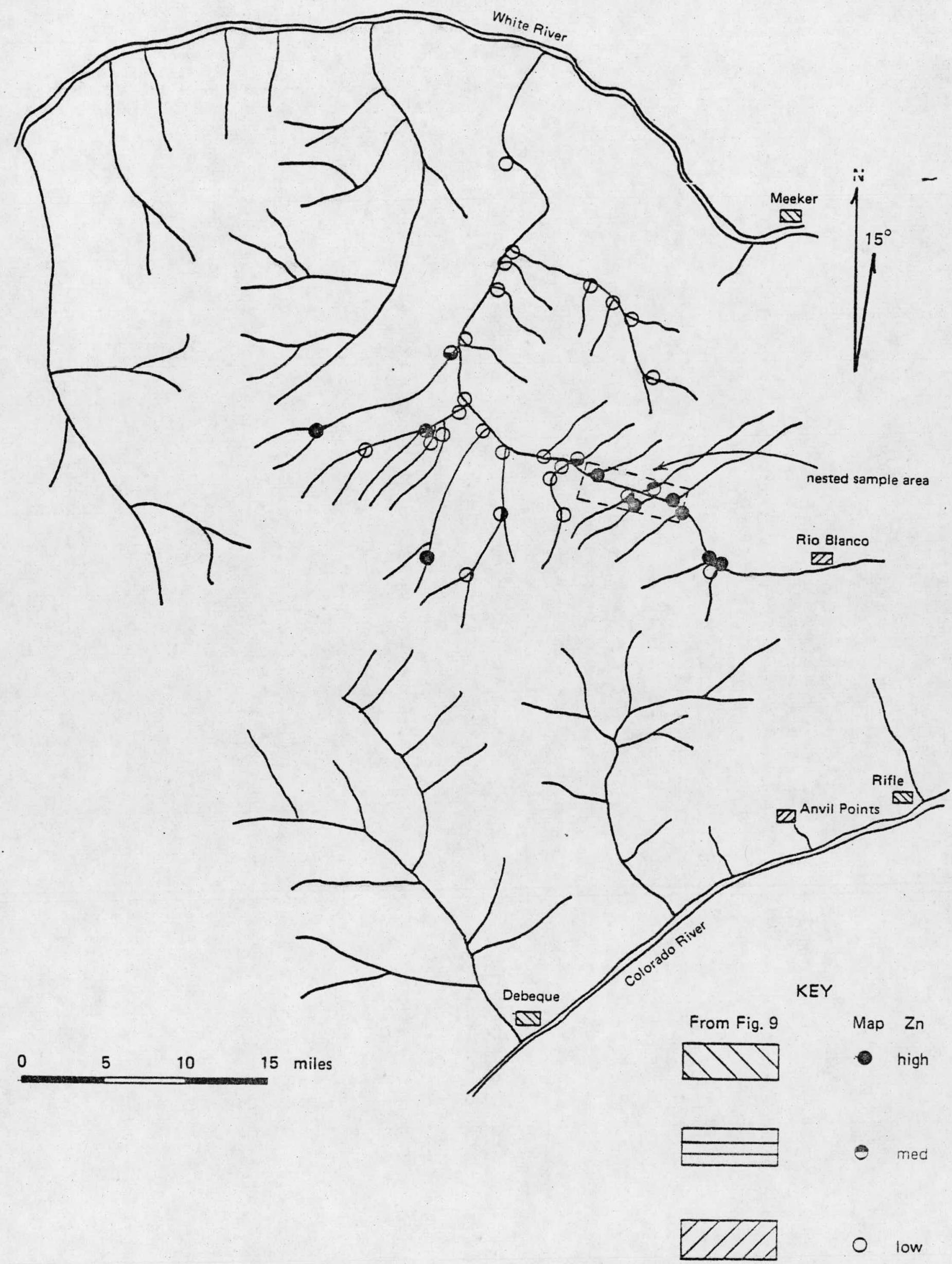
eastern segment is where the nested design is located for Piceance Creek and that the nested values for Mo are relatively low and the values for $\mathrm{zn}$ are relatively high just as they are for the stream junction data. Thus it may te interpreted that the nested samples are expressing the higher concentrations of $\mathrm{zn}$ and lower concentrations of Mo and not expressing the larger regional component.

From mapping the distribution of these two elements for one creek, it becomes apparent that in many instances, the high values at the heads of streams are not reflected by samples further downstream. Because of the non-anomalous nature of the Piceance basin, sampling at random within a locality will express the nature of the stream as well as sampling the downstream end of the locality.

Although the sampling in this study was not designed to answer questions such as what is influencing the geochemical distribution in the basin, a few general conclusions can be drawn. From stream junction data, it is found that for all the measured constituents -- $\mathrm{zn}$, Mo, Hg, and organic matter -there is a significantly greater concentration in the population of individuals making up the perimeter of the basin (all samples in the Green River formation and wasatch formation) as compared to the population of the interior (all samples in the Uinta formation). There is also a significantly greater concentration of Mo, $\mathrm{zn}, \mathrm{Hg}$, and organic matter in samples taken south of the Roan Plateau as compared to 
samples taken north of the plateau. This is similar to the data for $\mathrm{Zn}, \mathrm{Cu}, \mathrm{Li}$, and $\mathrm{Be}$ in surface soils (Ringrose, et al. 1976). Without further study, it cannot be determined what is causing this significant difference. Iithology is cne likely major factor influencing the populations because of the geological differences previously described. But many streams sampled north of the Roan plateau were dry; whereas, in the south, Roan and Parachute Creeks are perennial, being fed by springs as well as run-off. Thus, ground water may be playing just as important a role.

Correlations between the constituents under discussion showed significance only between $\mathrm{zn}$ and organic content for stream junction data. Mo has a correlation value of .19, but for 90+ samples. it should have been larger for significance different from zero at the $95 \%$ confidence level. Though a correlation was not made on the nested samples, one might conclude that the high organic samples on Parachute Creek will reflect the high geometric mean of Mo for Parachute Creek. But if Mo is being influenced by the kerogen rich Parachute Creek member, the relatively low Mo concentration of the stream junction samples downstream from the Parachute Creek member are not reflecting this. On the other hand, $\mathrm{zn}$ concentrations do seem to be affected as the stream junction samples in this location are relatively high in $\mathrm{Zn}$. 
NESTED VS. STREAM JUNCTION RESULTS

There has been some previous discussion concerning the comparison between the stream junction expected ranges and the nested expected ranges for the entire basin. From this comparison, it appears that the stream junction expected ranges are more realistic estimates than the nested expected ranges because they possibly reflect an additional larger scale variance component. If the results of the nested sampling plan with streams as a factor had shown the majority of the variance at the low scale level, the nested and stream junction samples could have been combined in estimating a preliminary baseline. In other words, all samples could have been treated as independent observations and an expected range could have served as a baseline.

The other question that arises from this discussion is how well the nested samples describe each individually selected stream when the stream junction results are also taken into consideration. Under the nested sampling discussion in the interpretation of nested samples section, it was recommended that expected ranges for the individual stream be used as preliminary baselines. In light of the fact that the nested results may be missing at a significantly higher component of variance, it is thought that only the nested sample result for Parachute, Roan and Black Sulfur Creeks reflect expected ranges that may be used as preliminary base- 
lines. Only these streams are considered because the restricted segments within which nested samples were taken are not much larger than the $10 \mathrm{~km}$ upper variance limit of the nested design for individual streams.

The segments of Piceance Creek and Yellow Creek which the nested samples represent are significantly larger than the upper scale variance of nested model design. The increased expected range of the stream junction samples indicates that the nested expected range result for the creeks may be in appreciable error because they fail to express the component of variance greater than $10 \mathrm{~km}$. Thus, it is reasoned that the stream junction expected ranges for Piceance Creek and Yellow Creek may be better estimates of the individual creeks than the expected ranges from the nested sample. 


\section{CONCLUSIONS}

Based upon the stream junction sampling results and considering the possible error that may be expressed by the sampling design, it is concluded that none of the streams' sediments considered in this paper are anomalous in trace element concentrations when compared to one another. However, it was found that the stream junction sediments did contain concentrations of Mo and As typically found in shales. This implies that the elements are abundant in the stream sediment medium. The $\mathrm{pH}$ measurements indicated that the sediments represent an alkaline environment which favors the mobility of trace elements such as Mo and As which can form anions. Thus Mo and possibly As could be potentially hazardous because of their relatively. high concentration and mobility. It was also found that there was a significantly greater concentration of Mo, $\mathrm{Zn}, \mathrm{Hg}$ and organic matter in samples taken south of the Roan Plateau as compared to samples taken north of the Plateau. From this sampling experience it is recommended that future stream sediment surveys with similar objectives use composite sampling to reduce the analytical load and the variance within streams.

The nested sampling of the major streams in the Piceance basin emphasized that within $2 \mathrm{~km}$ segments, a high percentage of the variance is at the lowest scale factor $(0-10 \mathrm{~m})$ for $\mathrm{Zn}$, Mo, Hg, and organic carbon. When streams are also con- 
sidered a factor in the nested design, the highest percentage of the variance occurs with that factor for Mo, Hg, and organic carbon. This high contrast between streams is thought to be reflecting the high variance between drainage systems rather than the variance between streams in general. on this combined streams basis, the variance components for $\mathrm{Zn}$ were more evenly spread between the factors.

Within the restricted limits placed upon each stream, except for Piceance Creek and Yellow Creek, it is recommended that the expected range values from the nested samples be used as preliminery baselines. From the all-stream nested data, a preliminary baseline for the basin is not possible because it is not clear as to what significance the stream variance component would have if tributaries of the major streams were selected randomly; therefore, additional nested sampling as outlined on p. 26 will be necessary to obtain reliable baselines for the entire basin. The expected ranges resulting from the stream junction samples give an estimate of the most likely concentrations to be encountered in the basin, but it does not reflect the scale of the variance which will be expressed with a geochemical map, if such a map were feasible. 


\section{APPENDIX A}

\section{Sampling Procedure and Sample Processing}

The sampling designs were followed as closely as was practical in the field. For the nested design, the midpoints of each sampling level down to $200 \mathrm{~m}$ were randomly positioned on the map. Then the actual sample sites were chosen at random in the field (a table of random numbers generated from a computer was used to randomly choose localities). If it was not possible to sample at randomly predetermined points for some reason, new random locations would be chosen out of necessity, realizing that the frequency of such procedure could lead to bias result. Choosing new locations was rare. Randomization is stressed to keep results as unbiased as possible.

The geologic population being considered in this study is all the possible $200 \mathrm{~g}$, minus 4 mesh sieved stream sediment samples taken from some specific point in the stream's channel, either at the sediment surface in midstream or on a point bar at water level. Each $200 \mathrm{~g}$ sample was placed in a paper bag made specifically to contain wet soils or sediments and allowed to dry at ambient air temperature. In the laboratory, $15 \mathrm{~g}$ representing the original $200 \mathrm{~g}$ were prepared for analysis by repeated splitting of the $200 \mathrm{~g}$ until approximately $15 \mathrm{~g}$ were left. These $15 \mathrm{~g}$ were then ground for approximately 7 minutes in a tungsten carbide vial and ball in a spex mixer mill. 


\section{Analysis}

Prior to analysis, batches of approximately 80 sample bags containing $15 \mathrm{~g}$ of ground sediment were chosen at random from all the samples to be analyzed. This was necessary so that any potential non-random analytical errors would be spread over the entire sample set and not concentrated in one group of samples which might, for example, have otherwise reflected a particular geographic area.

To analyze for $\mathrm{Zn}, \mathrm{Hg}, \mathrm{Cd}$, and As, approximately $\mathrm{I} g$ of sample was digested with 5:1 perchloric-nitric acid just below the boiling temperature of perchloric acid for approximately $11 / 2$ hours (standards were treated in like manner). Each sample was diluted to a specific volume and mixed thoroughly. The next day the samples were analyzed for As using the arsine method and the following day Hg was analyzed by a flameless $A A$ method and finally $\mathrm{Zn}$ and $\mathrm{Cd}$ were analyzed directly on the AA. After the first 20 or 30 samples, the analysis of As was discontinued because the As electrodeless discharge lamp was unstable at its recommended operating current.

The Hig method (modified from Hatch and Ott, 1968) is much more sensitive ( $1 \mathrm{ppb}$ ) than conventional AA methods ( 15 ppm). It assumes initially that all the mercury in the sample solution is in the form of $\mathrm{Hg}$ (II). The highly ozidizing perchloric acid digestion will assure this. Stannous chloride is added to an aliquot of this solution to reduce the Hg to the $\mathrm{Hg}^{\circ}$ state. The $\mathrm{Hg}^{\circ}$ is then aerated from solution into an 
absorption cell where its concentration is measured by the AA. Many sources describe this method in detail; for example (EPA, 1971). They differ primarily in what they use for a reducing agent. In this study $10 \mathrm{~g}$ of reagent grade $\mathrm{SnCl}_{2} \mathrm{H}_{2} \mathrm{O}$ were dissolved in $10 \mathrm{ml}$ of warm concentrated $\mathrm{HCl}$ and then diluted to $100 \mathrm{ml}$ with distilled water. One $\mathrm{ml}$ of this solution was used to reduce the $\mathrm{Hg}$.

There were problems in analyzing for $\mathrm{Hg}$, mainly because of the volatile nature of the element. At the beginning of the analyses when stock and working solutions were prepared, a few milligrams of $\mathrm{KMnO}_{4}$ were added to each solution to prevent reduction of the mercuric ion. A few weeks later it was discovered that an oxide of manganese which precipitated on the walls of the containers of the stock and working solutions was absorbing the mercury. This problem was corrected by relying on nitric acid (approximately . 15\%) and high concentration ( $1000 \mathrm{ppm} \mathrm{Hg}$ ) to preserve the mercuric ion in the stock solution, and by preparing the working solution just before the analysis.

During the analysis it also appeared that there was a mercury loss difference between standards and samples. This was discovered when one batch was allowed to sit over the weekend after being partially analyzed the preceding Friday. Upon trying to complete the analysis on the following Monday, it was discovered that mercury was not detectable in the standard but was still almost the same concentration in 
samples. The $\mathrm{pH}$ of the standard and sample solutions were less than 1 at the time that loss in the standard was detected. It is recommended that working standards be prepared the day of analysis with perchloric acid.

The direct method of analyzing for $\mathrm{zn}$ and $\mathrm{Cd}$ on the $\mathrm{AA}$ normally is a routine procedure. But initially, a problem did arise because of mixing the samples with glass stirring rods. When measurements for the concentration of $\mathrm{zn}$ and $\mathrm{Cd}$ were taken by the $A A$, there was a noticeable difference when the aspirating tube was positioned at the top of sample solutions as opposed to when it was placed near the bottom. At first this phenomenon was thought to be due to suspended particles. After allowing for settling of most of the particles, it was determined the solution above the sediment matter was not homogeneous. Mixing with teflon thimbles proved to be more thorough, faster, and gave a homogeneous solution.

Organic carbon was determined by the Walkley-Black method (Walkley, 1935). Although the method was developed as a rapid way to analyze soils, it works well for stream sediments also. The method is based on the reduction of the $\mathrm{Cr}_{2} \mathrm{O}_{7}{ }^{2-}$ ion by organic matter, wherein the unreduced $\mathrm{Cr}_{2} \mathrm{O}_{7}{ }^{2-}$ is measured by titration with ferrous sulfate. Ferrous and chloride ions can affect the determination, but it is unlikely that iron present is in its reduced state because of the highly oxidizing condition of the stream sediments. The 
qualitative test $\left(\mathrm{AgNO}_{3}\right)$ for chloride in samples most likely to have high chloride gave negative results.

As would be expected, the organic matter content of the stream sediment is low, averaging less than 1\%. Approximately one gram is used for determining the organic content in each sample. It was noted during test runs that when $I$ gram samples contained less than $0.5 \%$ organic matter, the analytical results were low (up to approximately $0.1 \%$ ). Although this error could have been overcome by using a larger sample ( 3 or 4 grams), it was decided to accept the result based upon I gram samples because of the time it would have taken to repeat the experiment and because of the shortage of ground sample material. A few samples reduced more than $75 \%$ of the dichromate on the first determination of the sample. These were repeated using less sample material.

The $\mathrm{pH}$ of the stream sediment samples were measured on a saturation paste with a glass electrode and a portable $\mathrm{pH}$ meter. The analysis of variance of the result of $\mathrm{pH}$ data showed that there was as much variance between repeated analytical measurements as there was between the samples themselves. The largest source of the analytical error was probably due to effect of dilution. Because of the heterogeneous nature of stream sediments, it was very difficult to be consistent with the ratio of soil to water. For some samples that consisted of fines and were fairly well sorted, the saturation point or sticky point was easily determined. 
But for other samples that were poorly sorted or consisted of large particles, the saturation point became nebulous. Thus the effects of the liquid junction potential or contact between the sediment and the glass electrode became highly variable.

Based upon the statistical results that there was as much variance between the stream junction localities as there was between replications, a few measurements by this method would yield as much information as measuring all the samples. Due to problems discussed above, it is recommended to take field measurements of water $\mathrm{pH}$ wherever it is possible (all active streams).

The analysis of Mo was done at the Project Central Analytical Facility at the University of Colorado. To obtain a total analysis, the samples were digested by the pyrosulfate fusion procedure (Meglen and Glaze, 1973). After dilution a colorimetric analysis of Mo was done using thiocyanate. The analytical error is about $10 \%$. 


\section{APPENDIX B}

Comments on the Application of Equations

The geometric mean, deviation and error, and expected range are discussed in U.S.G.S. Professional Paper 954-A, Miesch (1976a). The treatment of censored data is also included. From this reference the following equations were used to calculate the above parameters:

$$
x_{i}=\log _{10} y_{i}
$$

where $x_{i}$ is the log to the base 10 transformation of each of the analytical values $\left(y_{i}\right)$.

$$
\overline{\mathrm{x}}=\frac{\Sigma \mathrm{x}_{i}}{\mathrm{n}}
$$

where $\mathrm{n}$ is the number of independent analytical values.

$$
s_{\varepsilon}^{2}=\frac{\sum\left(x_{i}-x\right)^{2}}{n-1}
$$

where $s_{\varepsilon}^{2}$ represents the sample variance.

$$
\mathrm{GM}=10^{\overline{\mathrm{x}}}
$$

where GM is the geometric mean.

$$
\text { GD }=10^{S_{\varepsilon}}
$$

where GD is the geometric deviation.

$$
\mathrm{GE}=10^{\left(\mathrm{S}_{\varepsilon} / \mathrm{n}_{a}\right)^{1 / 2}}
$$

where $G E$ is the geometric error and $n_{a}$ is the number of sample replications.

$$
G D_{n}=10^{\left[\left(\log _{10} G D\right)^{2}-\left(\log _{10} G E\right)^{2}\right]^{1 / 2}}
$$

where $\mathrm{GD}_{\mathrm{n}}$ is the corrected geometric deviation for the analytical error. 
Expected $95 \%$ Range $=\mathrm{GM} /\left(\mathrm{GD}_{\mathrm{n}}\right)^{2}$ to $\mathrm{GM} \cdot\left(G D_{n}\right)^{2}$.

For the censored data the following equations were used.

$$
\bar{x}^{\prime}=\frac{\sum \mathrm{x}}{n_{\mathrm{d}}}
$$

where $n_{d}$ is numerator of detection ratio.

$$
\overline{\mathrm{x}}=\overline{\mathrm{x}}^{\prime}-\lambda\left(\overline{\mathrm{x}}^{\prime}-\mathrm{x}_{0}\right)
$$

where $x_{0}$ is the logarithm of the point at which the frequency distribution is censored; $\lambda$ is graphically determined (Miesch, 1967b, p. 87).

The equation used in the International Mathematical and Statistical Iioraries subroutine to calculate the variance components of the completely nested design with unequal subclass numbers was taken from Anderson (1952). The interpretation of the nested design is covered in Miesch (1976b) and Krumbein (1956).

The test for the significance of differences among means is also discussed in U.S.G.S. Prof. Paper 954A. The equation used to estimate $\mathrm{S}_{\mathrm{M}}$ was changed because of the unbalancing of the replication factor. To circumvent this problem, the error component was treated as part of variance of the following level. Thus, the equation for estimating $s_{M}^{2}$ would be stated as:

$$
E_{s}=\frac{s_{\beta}^{2}}{n_{\beta}}+\frac{s_{\gamma}^{2}}{n_{\beta}^{n^{n} \gamma}}+\frac{s_{\delta}^{2}+s_{\varepsilon}^{2}}{n_{B}^{n} \gamma^{n}}
$$

using the notation of U.S.G.S. Prof. Paper 954A.

Equations 17 and 18 were used for testing the significance between two means where the variances are unknown 
(Walpole, 1972, p. 242).

$$
\begin{aligned}
& T=\frac{\left(\bar{x}_{1}-\bar{x}_{2}\right)-\text { do }}{\left(s_{1}^{2} / n_{1}\right)+\left(s_{2}^{2} / n_{2}\right)} \\
& v=\frac{\left(s_{1}^{2} / n_{1}+s_{2}^{2} / n_{2}\right)^{2}}{\frac{\left(s_{1}^{2} / n\right)^{2}}{n_{1}-1}+\frac{\left(s_{2}^{2} / n_{2}\right)^{2}}{n_{2}^{-1}} \text { (degrees of freedom) }}
\end{aligned}
$$

The sample calculation for calculating the variance ratio for Mo using the nested analysis results are shown as follows (Miesch, 1976b, p. 101-106).

Given: $s_{\beta}^{2}=.73 \times .0552=.0403$

$$
\begin{aligned}
& s_{\alpha}^{2}=0 \\
& s_{\beta}^{2} \simeq 0 \\
& s_{\gamma}^{2} \simeq 0 \\
& s_{\delta}^{2}=.17 \times .0552=.0094 \\
& s_{\varepsilon}^{2}=.06 \times .0552=.0033
\end{aligned}
$$

One sample per locality (stream) would result in the following ratio:

$$
v_{m}=\frac{s_{B}^{2}}{\frac{s_{\delta}^{2}}{n}+s_{\varepsilon}^{2}}=\frac{.0403}{\frac{.0094}{1}+.0033} \simeq 3 .
$$

\section{Computer Programming}

This report used three programs extensively: a plotter program to plot and label sampling sites; a one-way analysis of variance program to estimate the variance within samples (analytical error) and to estimate the variance between 
samples; and an analysis of variance program to estimate the variance components of the factors of the hierarchial sampling design.

\section{Plotter Program}

This program (Table 7) reads the latitude and longitude stated in degrees, minutes, and seconds from cards and plots the position ( + ) with a number (sample number or concentration, etc.) labeling the position. To generate a plot, the program will first ask for a reference point (XZERO, YZERO) and the scale from the user. The program will expect the reference to be located in the quadrant shown in Figure 12 . It is important to note that in the program, $Y$ represents latitude and $x$ the longitude-- With the reference point as shown, all $y(4)$ values will then be negative and aII $x(4)$ values will be positive. 'Scale' in the program is adjusted until all outer points are within defined borders. Also note that the number 1.295 is the conversion factor between latitude and longitude. It will vary slightly depending upon the latitude of the sampling area. It should be warned that this program will not work on a Tectronic reacout scope because it will not accept input/output statements mixed with the plotter statements. 
Table 7 . Listing of the plotter program.

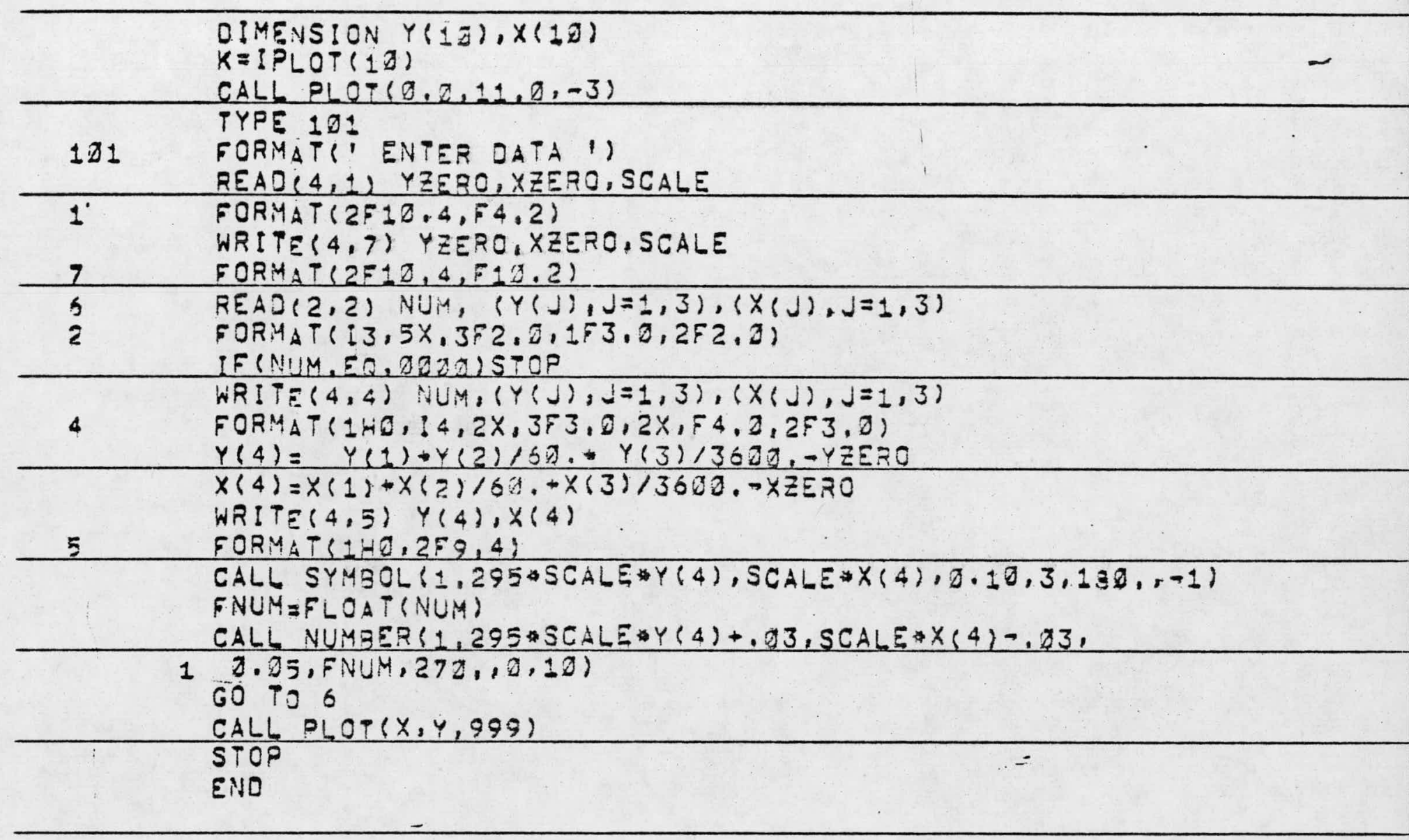




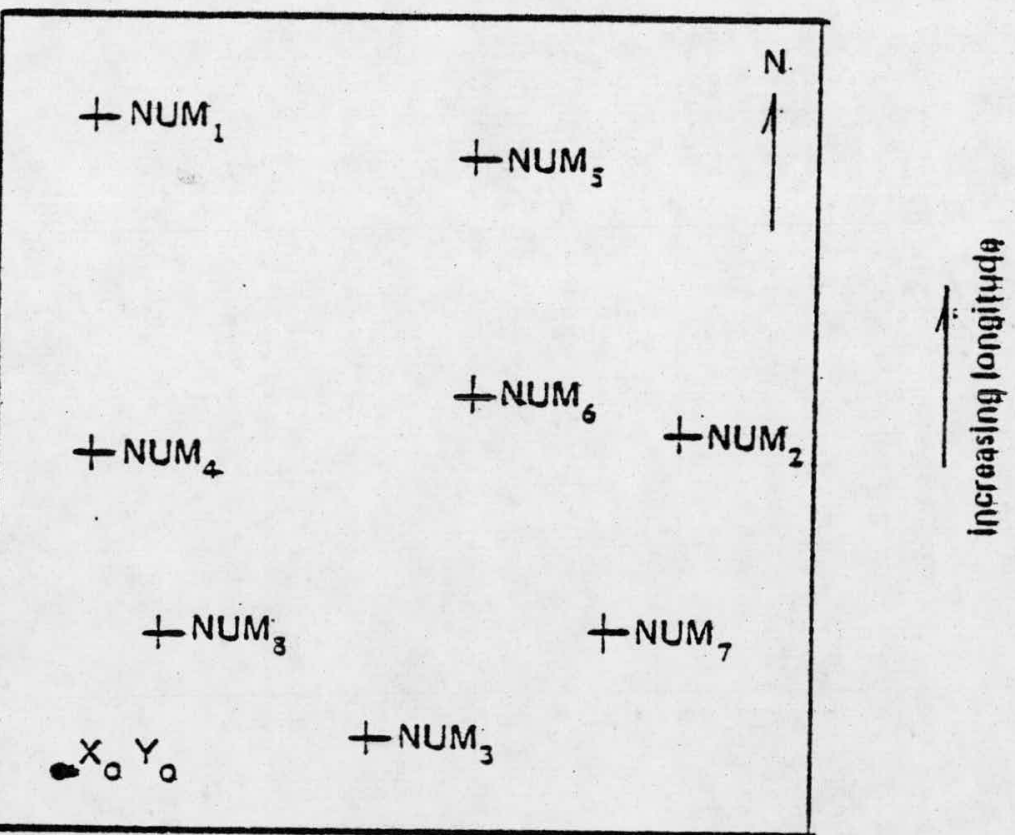

increasing latitude

Figure 12. Sample results of plotter program.

\section{One-Way Analysis of Variance Program}

This program is designed to handle groups with unequal replication. Each sample number (see Table 9 ) represents a group. For example, 035 is a group with no replications while 041 is a group with 3 replications. Note that some sample numbers indicating replications are only indicating that one of the constituents was repeated. The purpose of the program listed under Table 8 is to Iist for each group all the values of the constituent of interest and to separate each group of values with a zero (see Table 10). Note that all values are transformed to the log base 10. (If a data value is zero, .05 will be added to it before transformation takes place.) 
Table 8. Listing of program which regroups one constituent at a time from Table 9 for the one-way analysis subroutine program.

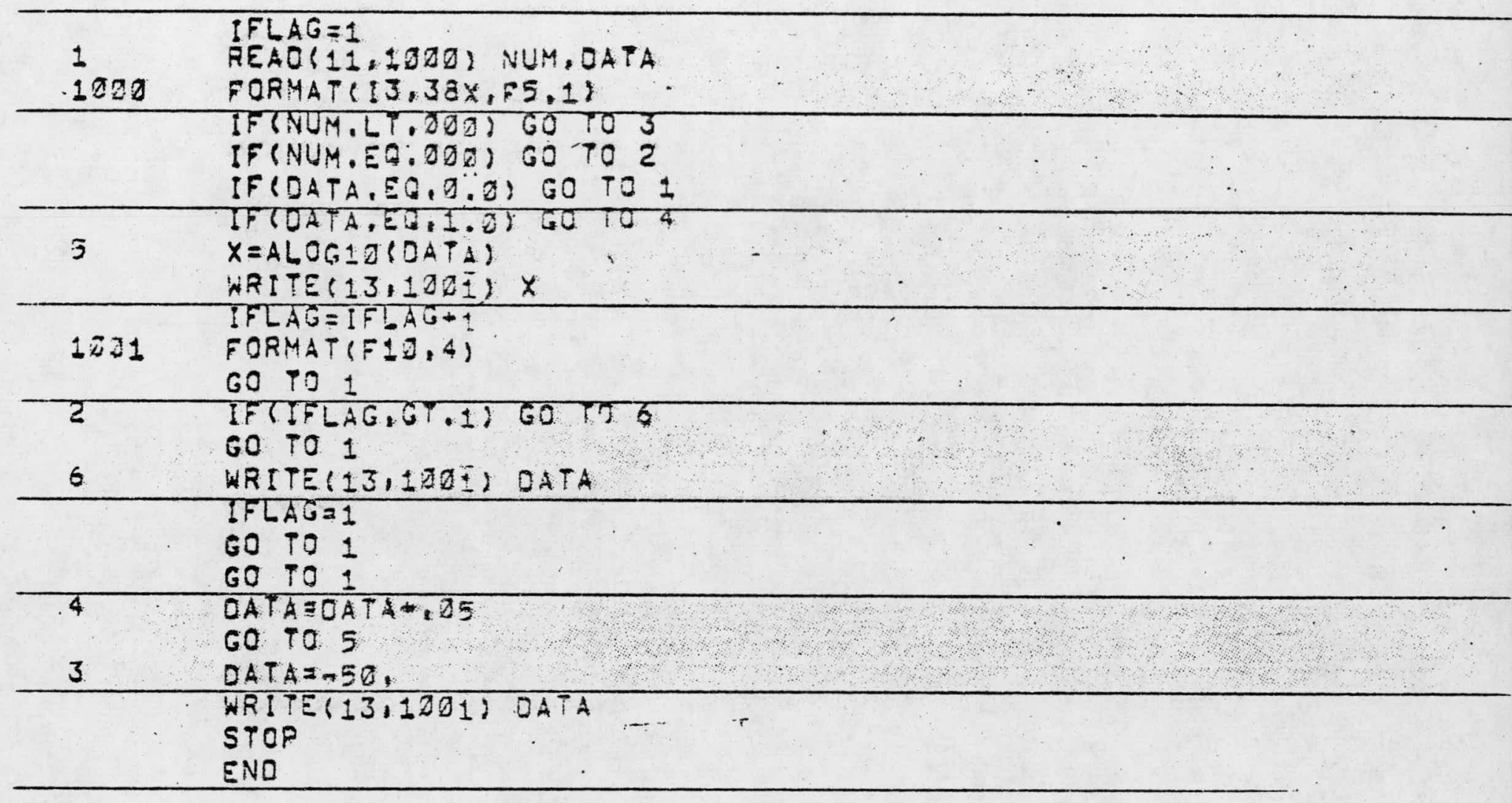


Table 9. List of stream junction analyses for each stream locality.

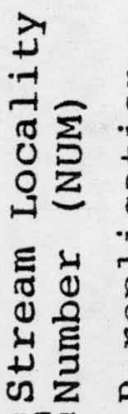

035

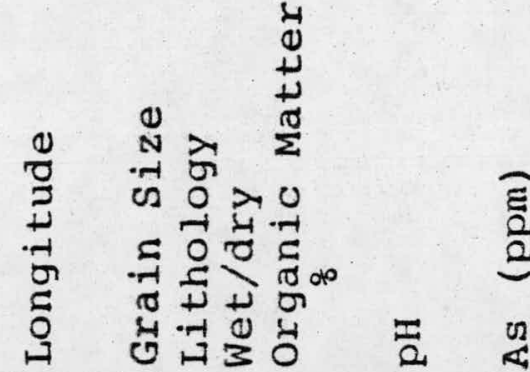

$3933081974645311.048,40$
छี छี

$\widehat{\underline{\Xi}}$

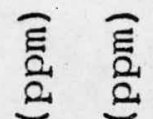

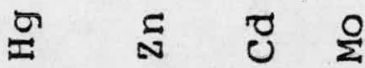

$.3034 .53 .21 ! .3$
238

$38 R$ $394433+73001233$

39

240

$394404478309133,967.92$

10.4 .1651 .82 .1

\begin{tabular}{|c|c|c|c|c|c|}
\hline 240 & 394724198022742 & 2.388 .30 & 7.9 & .17 & 68.41 .6 \\
\hline $\begin{array}{r}241 \\
417 \\
44= \\
\end{array}$ & 394741128032352 & 11.108 .20 & & $\begin{array}{l}.29 \\
.20 \\
.20 \\
\end{array}$ & 70.23 .51 .1 \\
\hline
\end{tabular}

942

$3943141280428429,223.15$

$42 R$ .2560 .32 .11 .0

344

$344 R$

$44 R$

$394711138054332 x 1.597 .828 .3 .1969 .62 .1 .5$

7,95

$$
2.7 .1378 .93 .2
$$

\begin{tabular}{|c|c|c|}
\hline $\begin{array}{r}946 \\
46 ?\end{array}$ & $3947361280604520.228,10$ & $\begin{array}{l}.3160 .41 .9 \\
.27\end{array}$ \\
\hline $\begin{array}{l}0481 \\
0481 R\end{array}$ & $\begin{array}{r}3942561083825420.147 .97 \\
8.05\end{array}$ & .2365 .19 .91 .3 \\
\hline $\begin{array}{l}9492 \\
6498\end{array}$ & 3949301000943520.377 .95 & $\begin{array}{l}.1958 .71 .91 .8 \\
.17\end{array}$ \\
\hline $\begin{array}{l}5501 \\
5012 \\
501 R\end{array}$ & 3948411081132420.118 .05 & $\begin{array}{lll}.27 & 49.91 .8 \quad .7 \\
.36 & \\
.25 & \\
\end{array}$ \\
\hline 5018 & & .2853 .21 .8 \\
\hline 2522 & $394644108102332+.238,30$ & $.36 \quad 43.29 .99 .4$ \\
\hline $522 R$ & 8.53 & \\
\hline 3561 & $394925108101332 \quad 01.928 .02$ & .4651 .09 .91 .2 \\
\hline $5561 R$ & 8.25 & \\
\hline 2572 & $394953108114732 \quad 0 \quad .238 .15$ & .5046 .42 .12 .8 \\
\hline $\begin{array}{l}572 R \\
572 R\end{array}$ & 8.40 & .40 \\
\hline
\end{tabular}


Table 9. (Cont.)

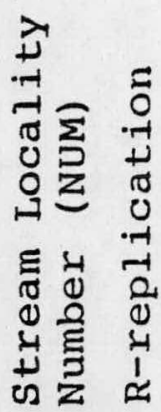

0602 602 R

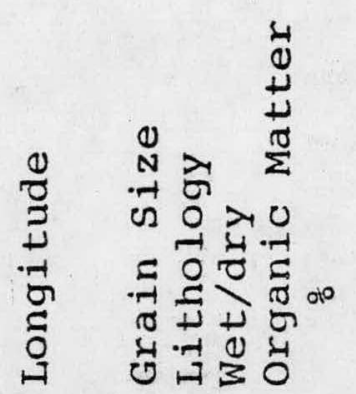

3950221081436321.178 .29
हू

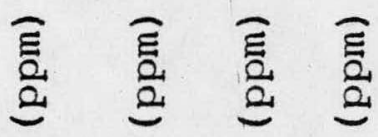

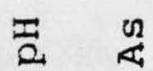

요 ह

.7339 .43 .21 .6

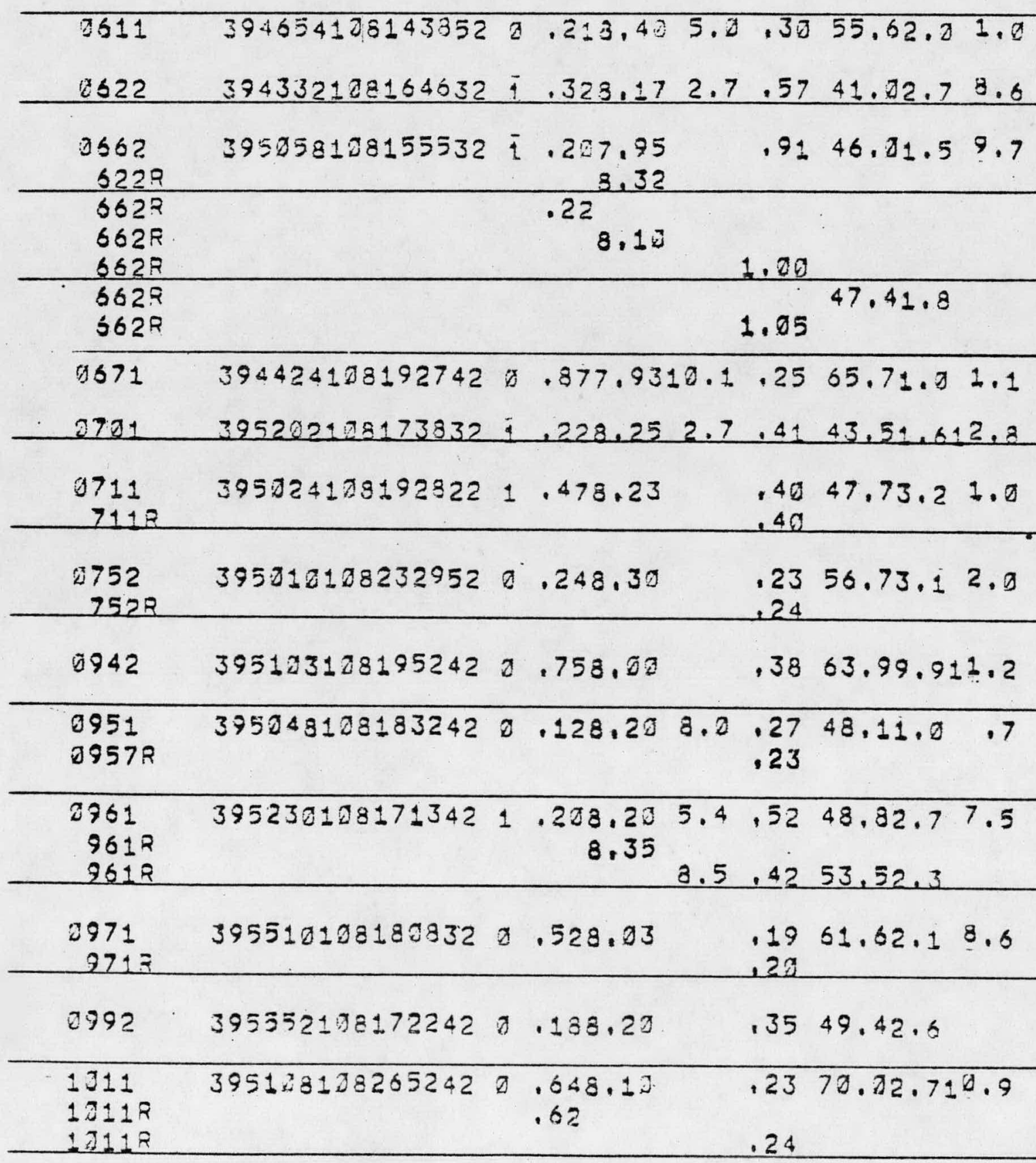


Table 9. (Cont.)

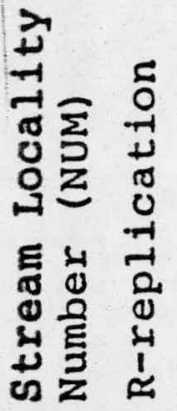

1941
प्र

ปే

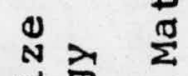

-

is $0>0$

ᄃ

-

(1)

Чैन

3955321082515320.338 .20
हू हूँ हू हू

छू हू ڤ

I) ก

$.2860 .62 .6 \quad 8.9$

$\begin{array}{lllll}1251 & 395555178252852 & .578 .35 & .4350 .69 .99 .2\end{array}$

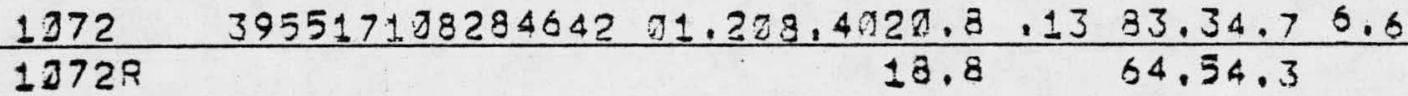

$\begin{array}{llll}1101 & 395844108221542 & 0.148 .35 & .1944 .14 .24 .5\end{array}$

$11113959091082839420.763 .00 \quad .2457 .31 .97 .1$

$11213959141082751520,228.25 \quad .2356 .32 .75 .8$

$1171 \quad 4024391081946520.423 .30 \quad 12952.79 .911 .4$

$1 \pm 71 R$

11718 .95

$1171 \hat{\mathrm{T}}$ 8,47

$1191 \quad 4037221082142320.298,33$

$1191 R$

.25

$\begin{array}{lllll}1242 & 3958441080846420.128 .40 & .4046 .71 .85 .9\end{array}$

$1251 \quad 3957501280720420.168 .20 \quad .4953 .79 .94 .2$

$12613957221088627321.728 .37 \quad, 3958.29 .96 .8$

$1281 \quad 39535810804383211.018 .15 \quad .25 .72 .44 .24 .0$

$1281 R$

$1281 R$

8.60

$1301420024108140552 \mp .428 .125 .3 .3250 .53 .25 .1$

$13113959571081438520.178 .35 \quad .2367 .22 .94 .9$

$1321395829498151352 \pi .178 .222 .6 .2439 .22 .56 .3$

$13414005081081432311.188 .42 \quad .5136 .69 .93 .7$

13412

.21

$1372 \quad 40295713823582 \quad 11.628 .95 \quad, 4358.94 .58 .1$ 
Table 9. (Cont.)
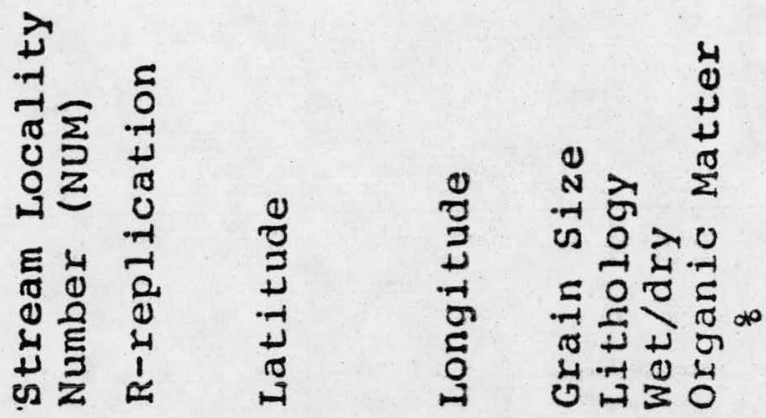

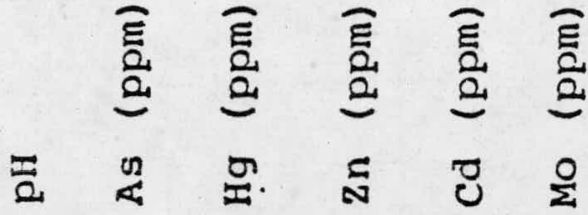

1381 $1381 R$

4098371282315531.688 .55

$.26 \quad 47.95 .95 .9$

$1381 \%$

.67 17

$1381 \mathrm{~F}$

$1381 R$

.2049 .35 .2 26

$1392403653198255152 \pi .258 .35 \quad .2147 .64 .85 .2$

13929 8.57

14124010331083001211.158 .355 .3 .3849 .21 .17 .3 $14127 \quad 5.3,2950.32 .6$

$1422 \quad 40103212833153113.368 .20 \quad, 2984.19 .99 .1$

$14514939351283814231.178 .14 \quad .3348 .23 .27 .3$

$1451 R$

$1451 \%$

8,35

.29

1461

$40392210840532 \quad 311.008 .22$

.3374 .53 .319 .3

14619 .54

1472

$4005111084627231,348,20$

.3454 .29 .96 .6 .35

$1481 \quad 40052510846532311.238 .15$

.3539 .21 .75 .8

$1512 \quad 4202221075442331.527 .85 \quad .3643 .81 .17 .2$

$\begin{array}{lllll}1521 \quad 40005513758385 & 30 & .128 .45 \quad .3167 .69 .97 .5\end{array}$

$1562 \quad 3930061075362412.338,3210.9 .4159 .83 .37 .7$

$1562 R$

$2.7 \cdot 33 \quad 78,84.3$

$\begin{array}{llll}1581 & 39283910759145121.128 .56 & .6577 .27 .711 .1\end{array}$

$1581 \bar{R}$

1581 ? .7472 .47 .8

1611 16118 16118

$39785419805504 \quad 111.358 .32$

.3579 .34 .38 .3

.66

$1621 \quad 393354128063747 \quad 11.768 .22$

.3971 .03 .413 .8 
Table 9. (Cont.)

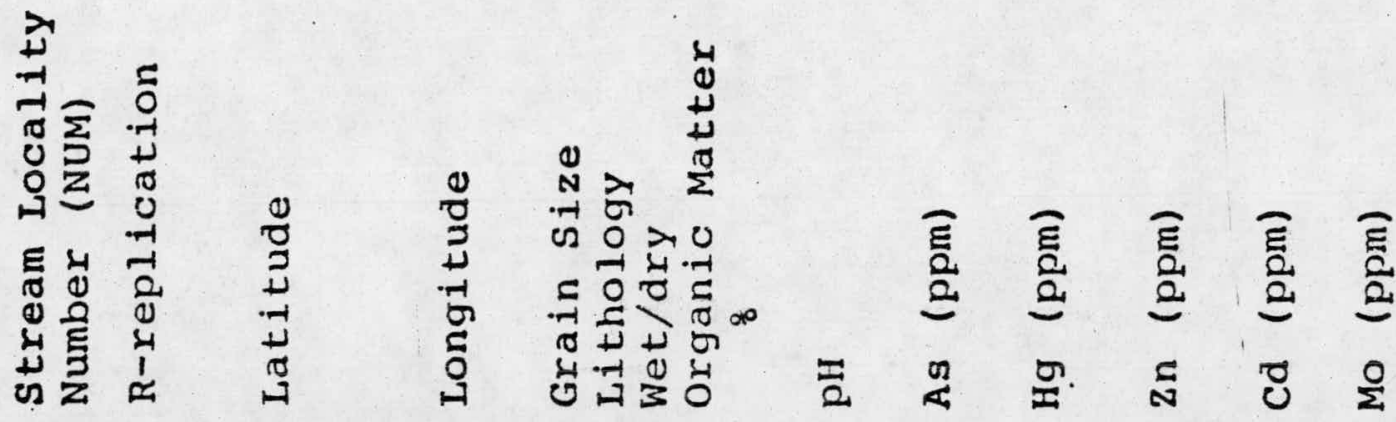

$1632 \quad 39314819897364112.688,35$ .4381 .84 .87 .9

1632 ?

$$
8.60
$$

$1642 \quad 39344110006213711.623 .3336 .1$ 8.53

$1542 R$

$393515178032837 ; .558 .25$ .2970 .29 .93 .3

16623935061880712271.628 .25 .3850 .72 .45 .7

1672

$393609188083237 \quad 1.778,27$

$.38 \quad 65.32 .65 .1$

1682 $393617408360137 \div .328,21$ .2963 .59 .93 .5

1691

$393755102062235 \div .658 .15$

.4461 .59 .93 .8

1701

$39263512803123111.148,11$

$.5554 .73 .6^{5.2}$

1721 39195610813773 i1 $.368,29$

$1721 R$ 3.0 .3255 .74 .8

1731 3922061981535511.718 .30 .3553 .83 .27 .8

$1752 \quad 39224310821263110.218 .53$ 17528 8.55 .3727 .29 .93 .6

$176139224410821305111,348,30$ $.44 \quad 64.24 .85 .9$ 1841 $39235810815413171.227,98$ .4071 .54 .11 .4 $1852 \quad 3924521081541211.488 .1218 .3,3478.53,16.7$ 191239273810814322111.888 .20 $12129 \quad 8.33$ .3671 .52 .65 .9

$192139272410819352111.248 .2229 .5,3272.33 .26 .4$ 25813.9291519819225112 .828 .4027 .5 .2277 .13 .36 .8 22818 42.1 .1368 .44 .2 
Table 9. (Cont.)

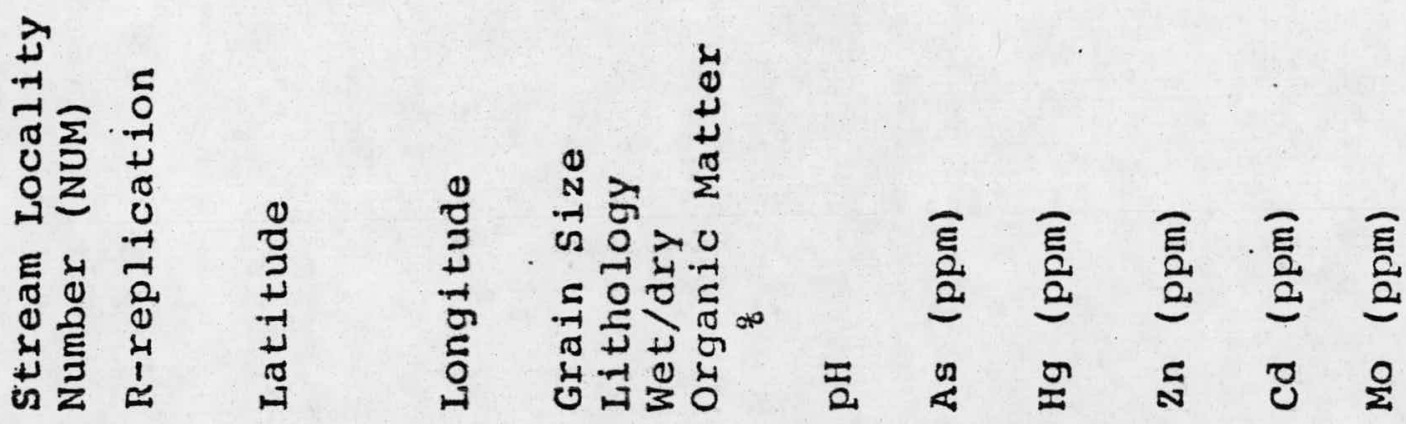

$2111 \quad 39301810823154113.108 .12 \quad .37115 .92 .55 .9$

\begin{tabular}{lllll}
\hline 2211 & 39304410828123 & 112.968 .13 & .4174 .94 .95 .3
\end{tabular} $2211 \pi \quad 8.42$

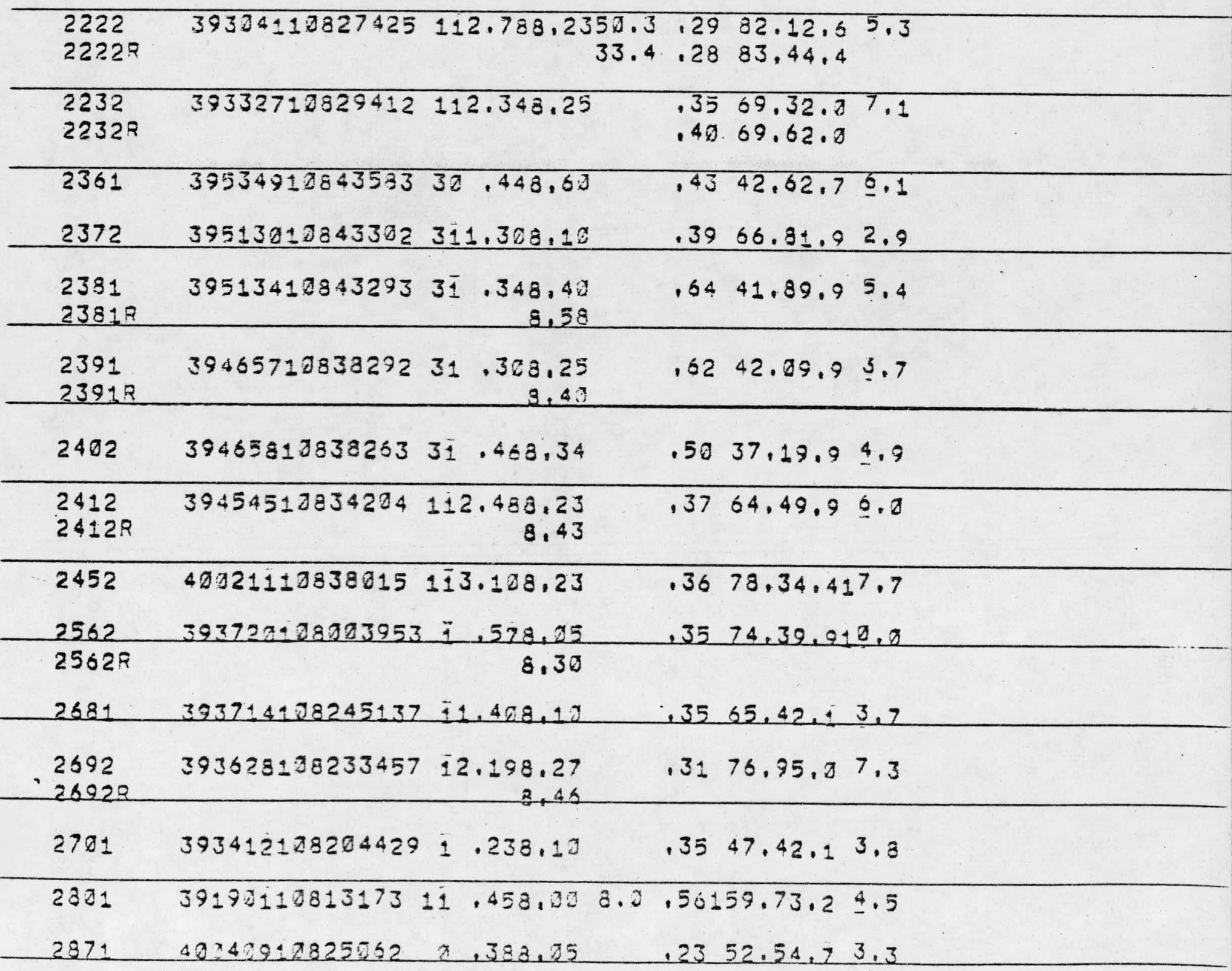


Table 9. (Cont.)
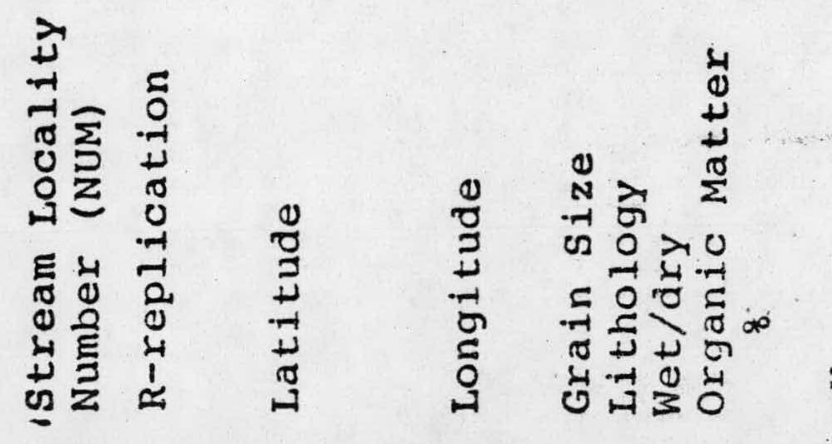

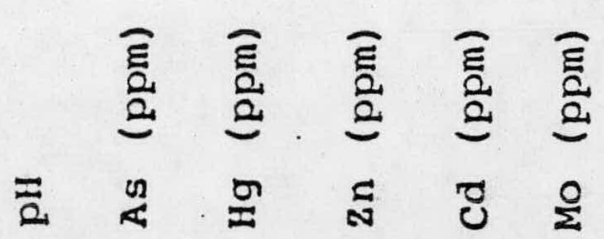
$2892 \cdot 3944271080032510.768 .02 \quad .3174 .02 .76 .6$ $29123931361274648211.323,03 \quad .52144 .24 .09 .0$ 29128 .52145 .7

$$
2922
$$$$
3931391074515
$$$$
.50151 .92 .6
$$$$
3.9
$$ 
Table 10. Listing the output of program listed in Table 8.

$\mathrm{Hg}(\log )$

$-0.5229$

0.0000

$-0.5198$

$-0.7959$

0.0000

$-8.3372$

0.0000

$-0.7696$

9. 2030

$-0.5376$

$-0.6990$

$-0.6992$

0.0090

$-0.6021$

$-12.6021$

0.0000

$-2.7212$

$-0.8861$

0.0000

$-0.5086$

$-7.5686$

0.2000

$-8.6393$

0.2030

$-0.7212$

$-0.7696$

a.9200

$-0.5686$

$-0.4437$

$-0.5850$

$-0.5528$

0.0000

$-0.4437$

0.0000

$-0.3372$

0.0002

$-0.3010$

$-0.3979$

ก. 2000

$-0.1367$

$-0.1024$

0.0000

$-0.5229$

0.0000

$-0.2441$

0.0020

$-0.0412$

0.0212

0.0212

0.0000 
Table 10. (Cont.)

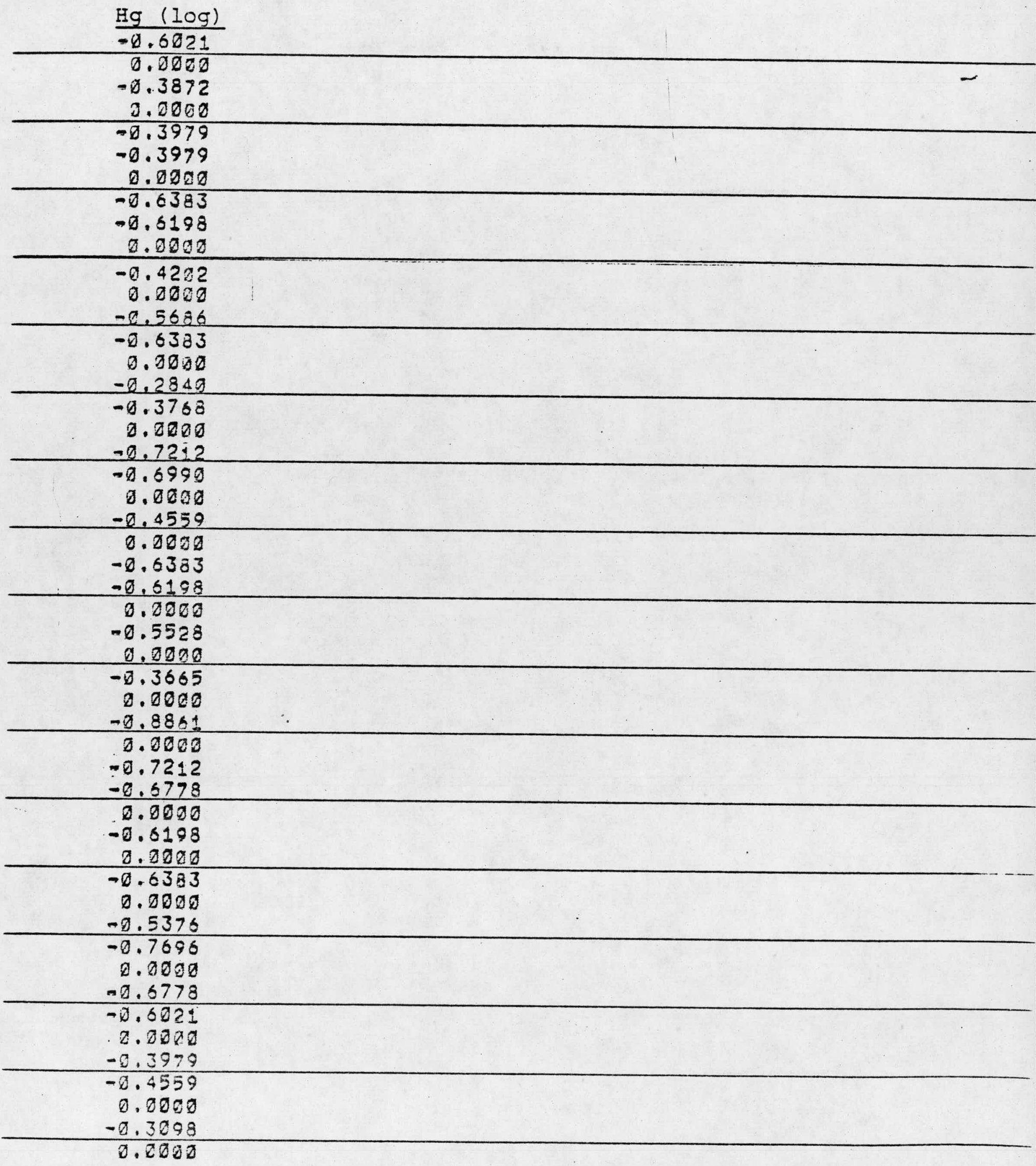


Table 10. (Cont.)

Hg $(\log )$

$-0.4089$

0.0000

$-0.6021$

$-0.5528$

0.0000

$-0.4949$

0.0000

$-0.6383$

0.0000

$-0.6198$

0.0000

$-0.2924$

0.3200

$-0.3665$

0.0080

$-0.5850$

$-0.7696$

$-0.6990$

$-0.5850$

0.0000

$-9.6778$

0.0000

$-8.42 \pi 2$

$-0.5376$

0.0000

$-8.5376$

0.8000

$-0.4815$

$-0.5376$

0.0000

$-0.4815$

$-0.2676$

0.2000

$-0.4685$

0.0000

$-0.4559$

0. 0020

$-0.4437$

0.0000

$-0.5086$

0.0008

$-0.3872$

$-0.4815$

0.0000

$-2.1871$

$-0.1388$

$-0.0915$

0.0000

$-0.4559$

$-0.1805$

0.2000 
Table 10. (Cont.)

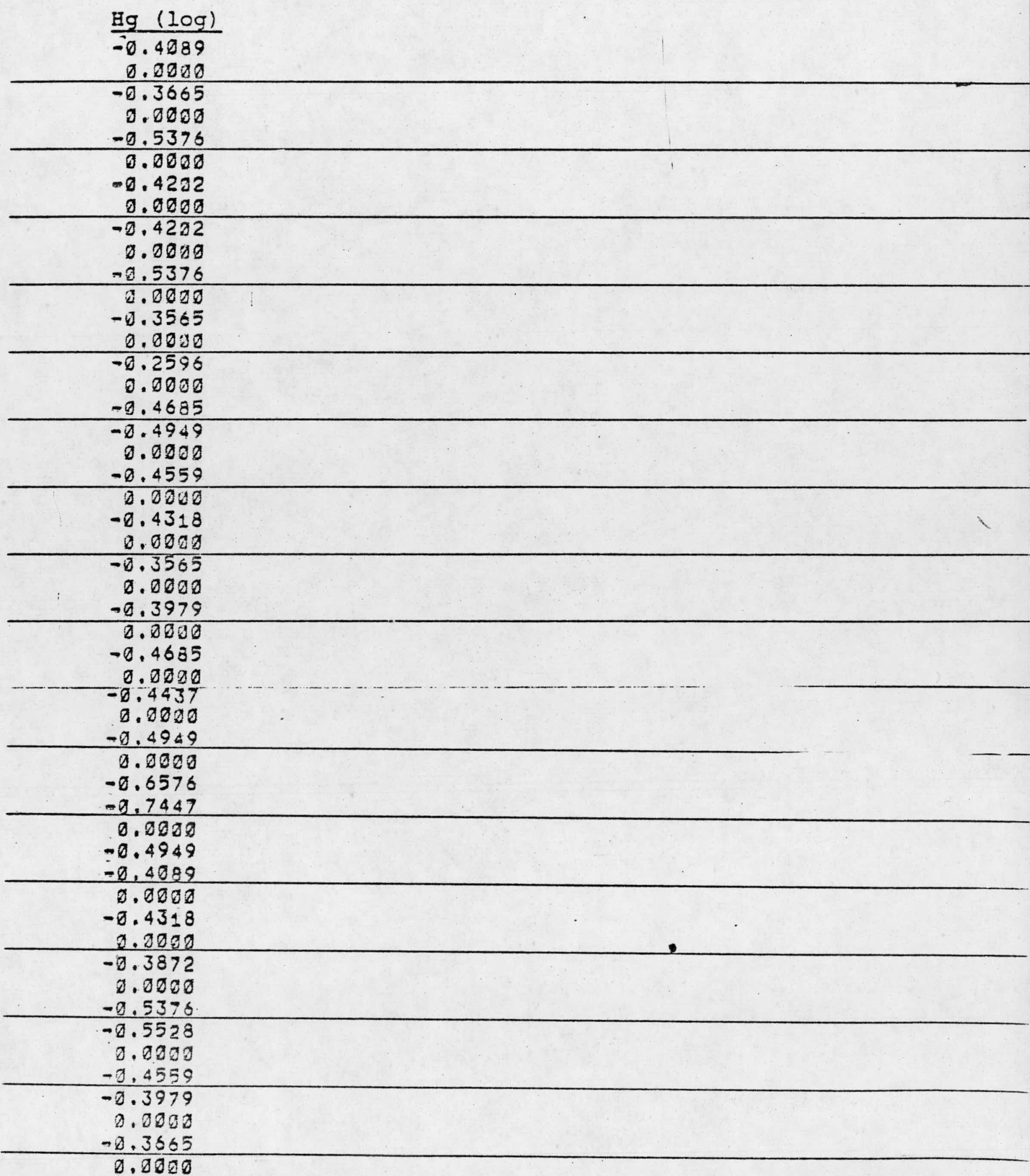


Table 10. (Cont.)

\begin{tabular}{r} 
Hg (log) \\
\hline-0.4089 \\
0.0000 \\
-0.1938 \\
0.0020 \\
-0.2076 \\
0.0000 \\
-0.3010 \\
0.0000 \\
-0.4318 \\
0.0000 \\
-0.4437 \\
0.0000 \\
-0.4559 \\
0.0200 \\
-0.4559 \\
0.0000 \\
-0.5036 \\
0.0000 \\
-0.4559 \\
0.0000 \\
-0.2518 \\
0.0000 \\
-0.6383 \\
0.0000 \\
-0.5086 \\
0.0000 \\
-0.3010 \\
-0.2840 \\
0.0000 \\
-0.3010 \\
0.0000 \\
-50.0000 \\
\end{tabular}


The program listed in Table 11 calculates the analysis of variance using the subroutine "ACRDAN' which is one of the IMSI statistical programs. Table 12 gives an example of the output for $\mathrm{Hg}$. The last number $(96)$ in the first row of output tells how many groups were in the input. The first column of the next 3 rows lists the sum of squares (S(I), $S(2)$, and $S(3)$ ) and the second column gives the degrees of freedom associated with each sum of squares. Below the first three rows, the first column lists the group mean of each group and the second column gives the variance within each group. The last row at the bottom gives the grand mean and the error parameter.

Nested Analysis of Variance Program

The test run of Mn data taken from McNeal, et al. (1976) for Roan Creek and Black Sulfur Creek will be used to illustrate how the program works. The nested model for Roan Creek and Black Sulfur Creek are shown in Figures 12 and 13 with $\mathrm{Mn}$ data. The diagrams are important because they clearly show the order in which the data must be loaded into the program. There are two inputs to the program (see Tables 13 and 14 for FOR 10.DAT and for FOR I2.DAT) which are labeled $\gamma$ (analytical values) and NL (see ANESTU, IMSI Library). For a given order of $Y$ there will be a corresponding order for NI.

Note that the $Y$ values of Roan Creek end with the flag 999 as do the $Y$ values of Black Sulfur Creek to signal the end of the data. Correspondingly, the NL's for Roan Creek 
Table 11. Listing of the one-way analysis program.

\begin{tabular}{|c|c|c|}
\hline E SET & 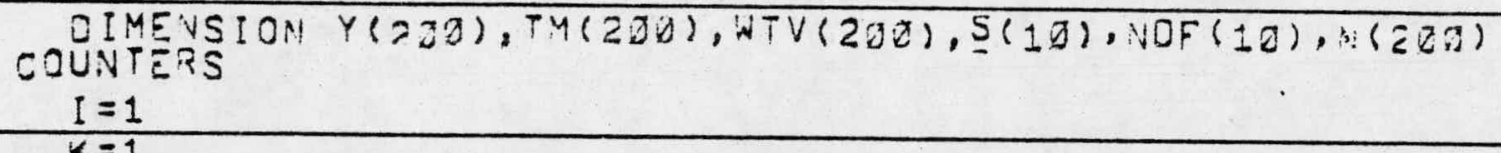 & - \\
\hline & $\begin{array}{l}K=1 \\
J=0 \\
I I=D\end{array}$ & \\
\hline 1050 & $\begin{array}{l}\text { WRITE }(4,1250) \\
\text { FORHAT }(1 H \theta, 1 \text { ENTER ELEMENT' } \\
\text { READ }(4,196 D) \text { ELEM } \\
\text { FORHAT(AG) }\end{array}$ & \\
\hline 1050 & 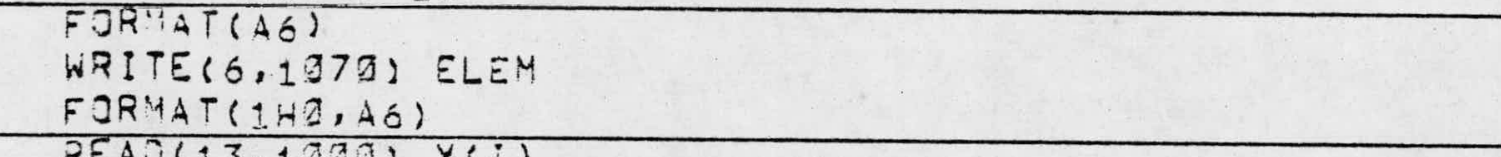 & \\
\hline 1000 & 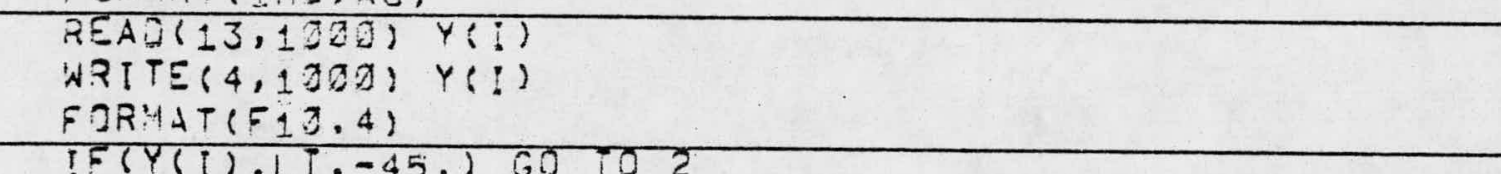 & \\
\hline & 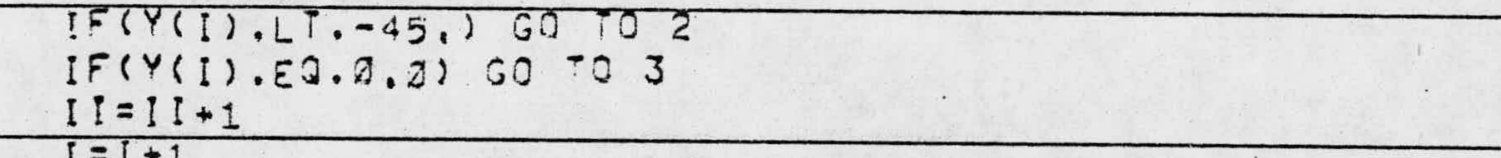 & \\
\hline 3 & 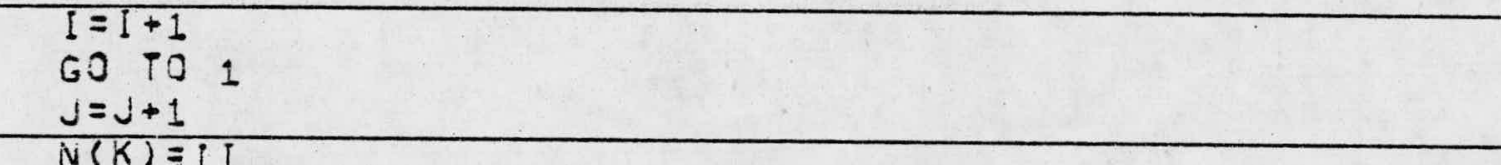 & \\
\hline & $\begin{array}{l}N(K)=I I \\
K=K+1 \\
I=9\end{array}$ & \\
\hline $\begin{array}{l}2 \\
1031\end{array}$ & 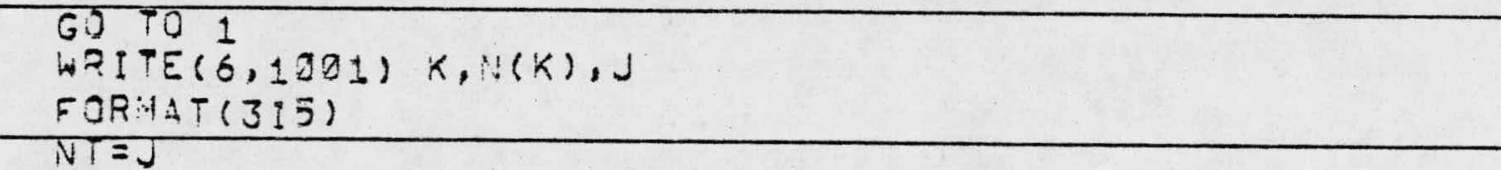 & \\
\hline & $\begin{array}{l}\text { CALL ACFOAN(Y,NT,N, TH, WTV, S, GH, NOF, IER) } \\
\text { WRITE (6, } 102 Z)(S(I), N O F(I), I=1,3)\end{array}$ & \\
\hline $\begin{array}{l}1220 \\
1230\end{array}$ & $\begin{array}{l}\text { FORMAT (F19.5, IR) } \\
\text { WRITE } 6,1030)(T M(1), W T V(1), I=1, N T) \\
\text { FORHAT }(2 F 10.3)\end{array}$ & \\
\hline 1040 & $\begin{array}{l}\text { WRITE }(6,1040) \text { GM, .ER } \\
\text { FORHAT }(F 10,4,112 i \\
\text { STOP }\end{array}$ & \\
\hline
\end{tabular}


Table 12. Listing the output of program listed in Table 11.

HG

97 * I M S LIUERT

3.92891

0.22339

4.15230

$-0.523$

$-0.708$

$-0.337$

$-0.770$

$-0.645$

$-0.602$

$-0.804$

$-0.539$

$-0.635$

$-0.745$

$-8.53 \%$

$-0.444$

$-0.337$

$-0.349$

$-0.12 \pi$

$-0.523$

$-0.244$

0.209

$-0.602$

$-8.387$

$-0.398$

$-0.629$

$-0.422$

$-0.603$

$-0.330$

$-0.712$

$-0.456$

$-0.629$

$-0.553$

$-0.367$

$-0.888$

$-0.700$

$-0.620$

$-0.638$

$-0.654$

$-0.642$

$-0.427$

$-0.313$

$-9.480$

$-0.577$

$-0.495$

$-9.638$

$-0.623$

$-0.292$

$\frac{6}{6}$

ST) WARNING

$45\{$ Sum of Squares, Degrees of Freedom

136

0.000

0.016

0.000

0.090

0.089

0.000

0.014

0.032

0.000

0,001

3.034

2.200

0.020

3.805

2.001

0.000

0.200

2.001

0.000

0.000

0.020

0.000

2,000

0.002

0,004

0.000

2.000

0.002

2,008

0.009

0,000

0.001

0.000

0,200

0.027

0.023

x. 022

2.200

0.000

0.001

0.000

0.220

0.000

0.000

$\downarrow$ Group mean of each group, variance within each group 
Table 12. (Cont.)

$-0.367$

$-0.660$

$-9.678$

$-0.479$

$-0.538$

$-0.512$

$-9.375$

$-0.468$

$-0.456$

$-0.444$

$-0.509$

$-0.434$

$-10.136$

$-0.318$

$-\tilde{2} .400$

$-0.367$

$-0.538$

$-8.42 \%$

$-0.423$

$-0.538$

$-9.356$

$-0.268$

$-0.482$

$-9.456$

$-9.432$

$-0.356$

$-0.398$

$-0.468$

$-9.444$

$-0.495$

$-0.701$

$-0.452$

$-0.432$

$-0.387$

$-0.545$

$-0.427$

$-0.367$

$-0.409$

$-0.194$

$-0.208$

$-0.301$

$-0.432$

$-8.444$

$-0.456$

$-0.456$

$-0.509$

$-0.456$

$-2.252$

$-2.638$

$-0.509$

$-0.293$

$-0.301$ 0,000

0.038

2.020

0.207

0.200

0.002

0.023

0.000

0.000

0.000

0, .

7.904

2.002

0.038

2,000

0.000

0.000

0.000

0.000

0.000

2.000

0.020

0.000

0.000

0.000

0.000

2,020

0.000

0.020

0.000

0,204

0.004

0.000

2.000

0.000

2.002

0.000

0.000

$\theta, 000$

0.000

0.000

9.020

0.000

0,000

0,000

3.000

0,200

$\pi, 003$

8,000

0,020

$\pi, 000$

0,000

$-8.4786$ 


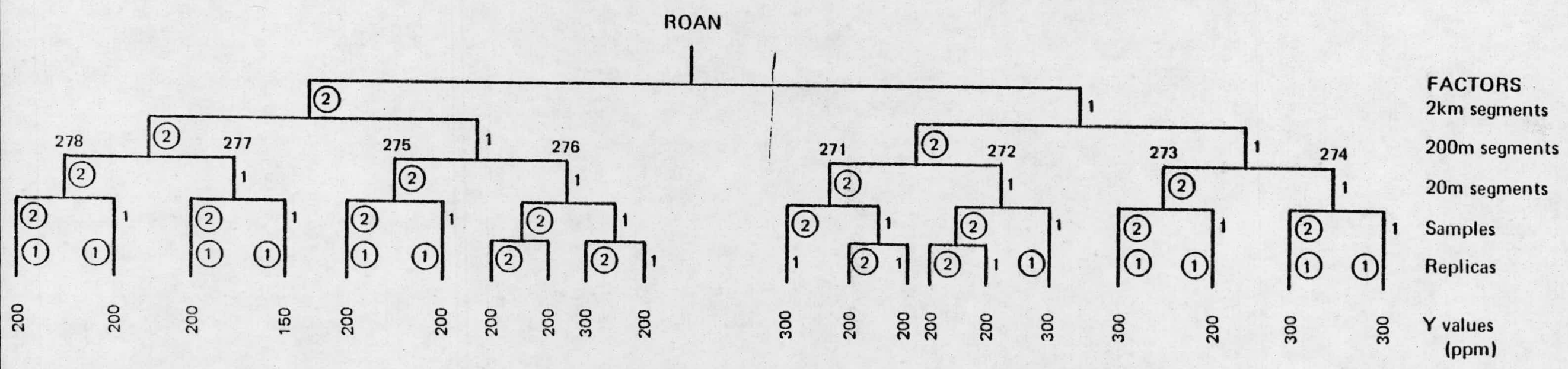

The circled numbers are the NL values which correspond to Table 13 (1ine 1) 
Table 13. Listing of input for program listed in Table 15.

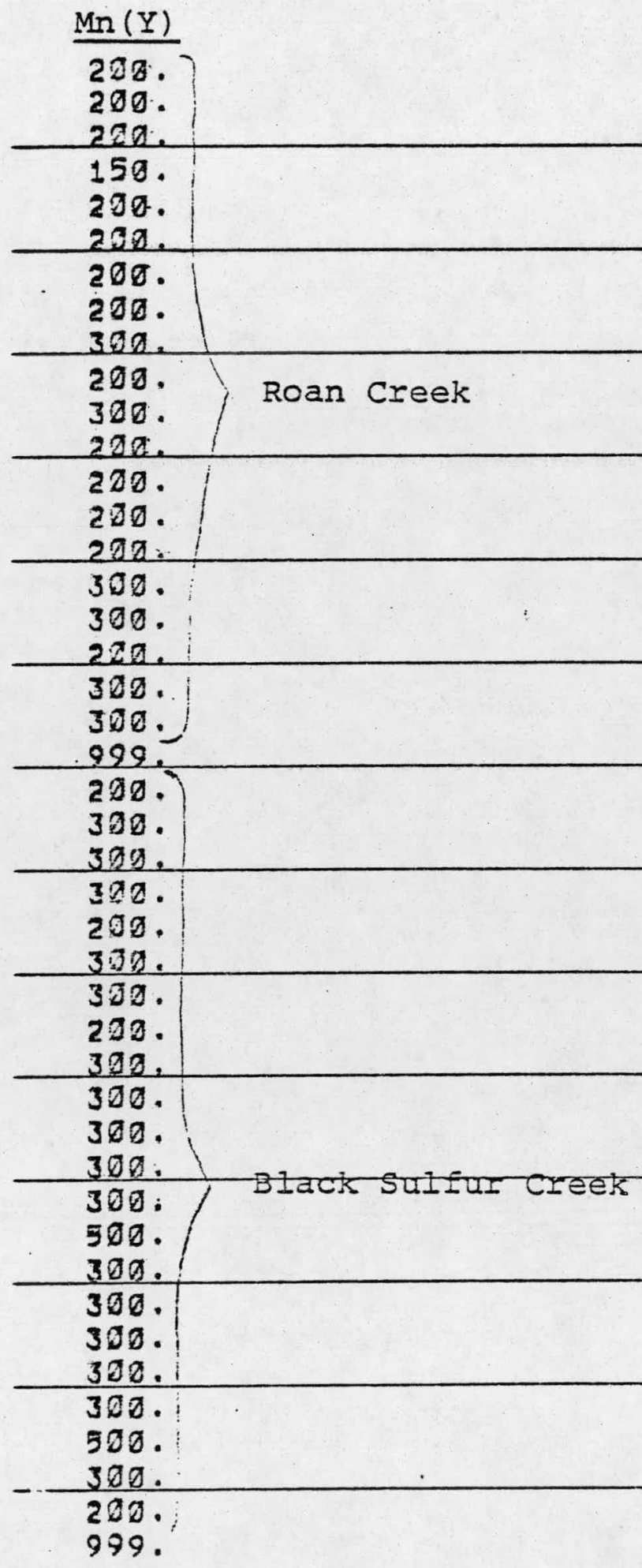


end with the flag 99 and the NL's for Black Sulfur Creek end with 90, indicating the end of the data set. (If there had been more than two creeks, then 90 would have been used only with last creek's NL values, the others being 99). Tie last set of NL values ending with 90 represent a nested model with both creeks instead of separate nested models for each stream as did the above groups of NL's.

The program (Table 15) will ask the following questions during the execution. First, a value for NF (number of factors in model) will be asked for. This means that since Roan Creek is the first nested model on the file, the value of NF will be 4 . Then the program will ask if data is good or bad (i.e., errors in input). If it is bad, it will go to the next set of data; if good, it will continue by asking to enter a stream label. It will then ask if there are more nested data which must be treated separately, or if it should merge all the preceding data into one large nested model, or if it should stop. In this case, a 0 would be entered and the data for Black Sulfur creek will be read in. NF would again be 4. At the end of this sequence of questions, the program will be told to merge. This time though, NF would be 5. In addition to the other questions, the program would also ask what element. In this case, Mn would be-entered. The output (Table 16) lists first the input for each stream (note the $Y$ values have been transformed to log base 10). Then, as explained in the one-way analysis program, the columns would first express the sum of squares and 


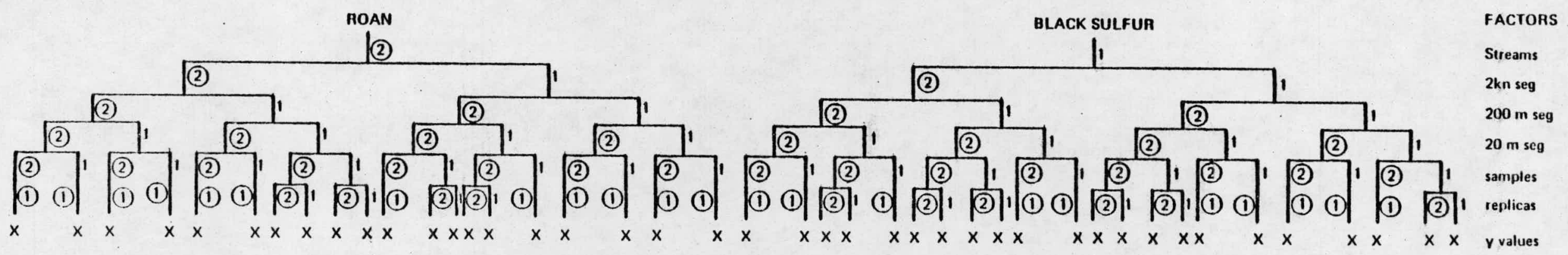

The circled numbers are the NL values which correspond to Table 13 (11ne 3)

Figure 15. Nested model representing both creeks using Mn data. 
Table 14. List of input for program listed in Table 15.

$2,2,2,2,2,2,2,2,2,2,2,2,2,2,2,1,1,1,1,1,1,2,2,1,2,2, \overline{1,1,1,1,1,99}$ $2,2,2,2,2,2,2,2,2,2,2,2,2,2,2,1,1,2,1,2,2,1,1,2,2, \pm, 1,1,1,1,2,97$ $2,2,2,2,2,2,2,2,2,2,2,2,2,2,2,2,2,2,2,2$ 
Table 15. Listing of program for calculating the analysis of variance for unbalanced nested design.

DIMENSION NL(1Z0), Y(200), S(100), NOF (120), EMS(122), J'KK(120)

DIMENSION NS(5DD), YY (500), YS (5QD)

DIMENSION CREEK(12), S10(100)

\section{IFLAG $=0$}

NCT $=1$

NYCT $=0$

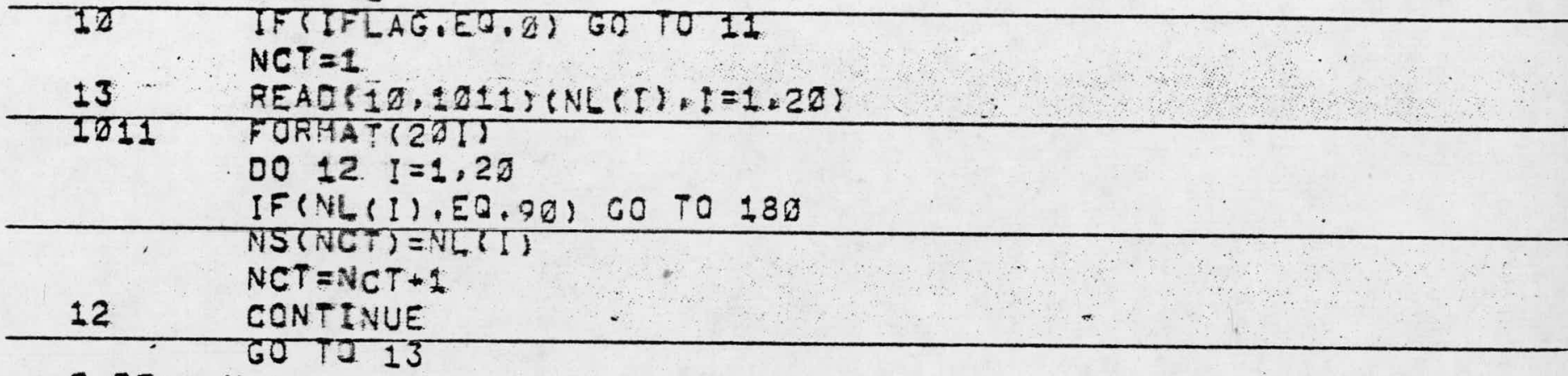

C READ NL

11 WRITE 4,1214 )

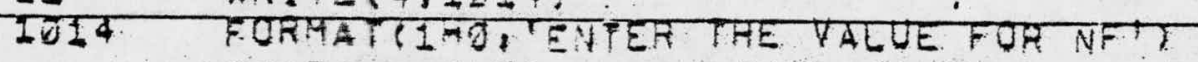

READ $64,10 \pm 5)$ NF

1015 FORMAT(II)

NF $1=N F+1$

$N F 2=N F-(N F+1) / 2$

NCT $=1$

13 READ(10,2000)(NL(I),I=1.20)

1292 FORMATCLQ!?

00. $22 \quad I=1.22$

If (NIS(I):NE.90! GO TO उD

IF $L A G=1$

GO T0 60

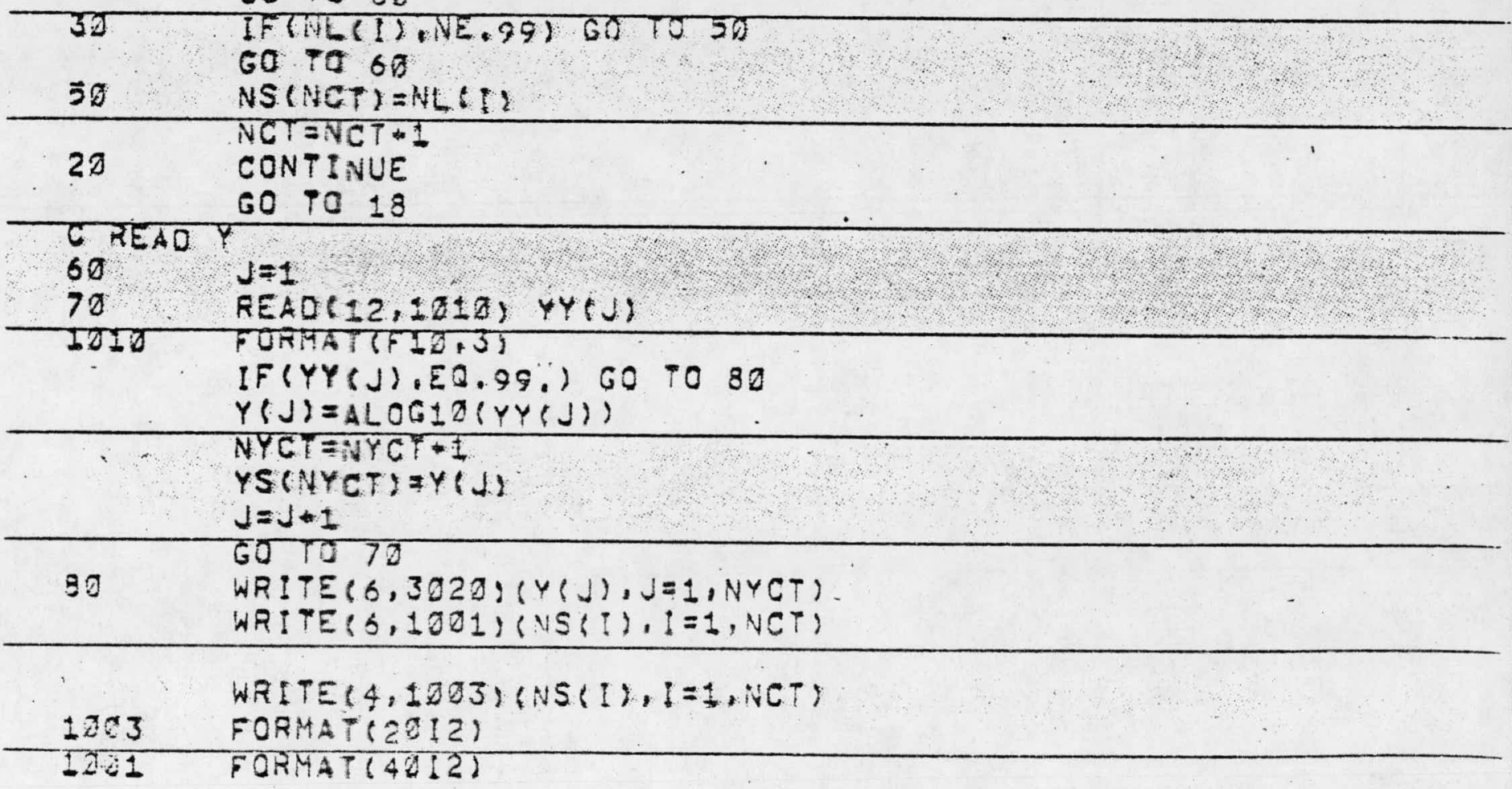


Table 15. (Cont.)

CALL ANESTU(NF,NS, Y, GM, S, NOF, EMS, INK,IER)

WRI TE $(4,2 D 20)(S(I), N O F(I), I=1, N F I)$

\begin{tabular}{|c|c|}
\hline रकद & $\begin{array}{l}\text { FORTAT (FID, }, \text { IID) } \\
\text { WRITE }(4,2230)(E M S(1), I=1, N F 2) \\
\text { FORMAT }(F 10,4)\end{array}$ \\
\hline 2050 & 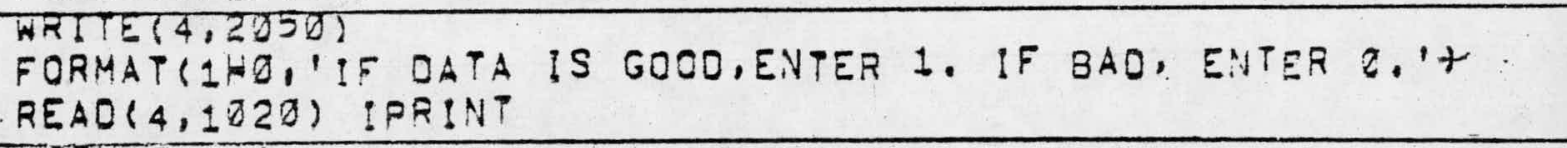 \\
\hline 1020 & $\begin{array}{l}\text { FORMITIIL) } \\
\text { IF(IPRINT. EQ } \\
\text { GOTO GO TO } 120\end{array}$ \\
\hline $\begin{array}{l}120 \\
2360\end{array}$ & 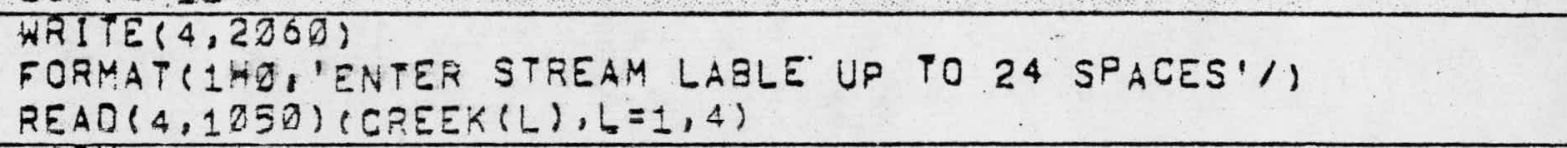 \\
\hline $\begin{array}{l}1750 \\
2270\end{array}$ & $\begin{array}{l}\text { FORHAT( } 4 \text { AS) } \\
\text { WRITE }(6,2270)(C R E E K(L), L=1,4) \\
\text { FORMAT(1HD, }(4 \text { A })\end{array}$ \\
\hline & $\begin{array}{l}\text { WRITE }(6,2020)(S(!), N O F(!), !=1, N F 1) \\
\text { WRITE }(6,2030)(E M S(!), I=1, N F 2) \\
\text { WRITE }(6,2240) G M, ! E R\end{array}$ \\
\hline $\begin{array}{l}2040 \\
150\end{array}$ & 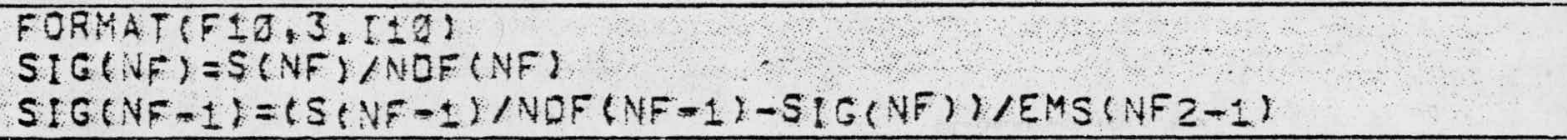 \\
\hline & 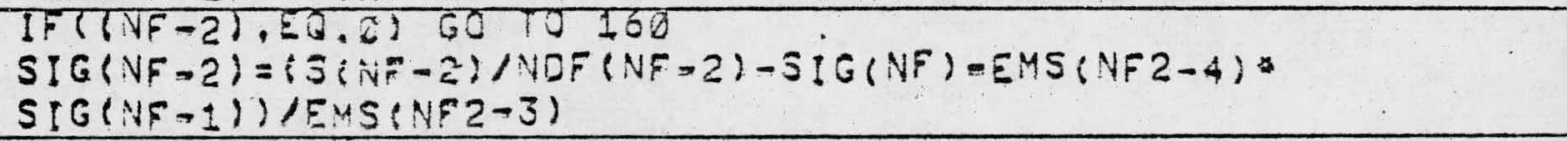 \\
\hline & $\begin{array}{l}\text { IF( }(N E-3), E Q, D) \text { GO TO } 160 \\
S ! G(N F-3)=(S(N F-3) / N D F(N F-3)-S I G(N F)=E M S(N F 2-3) \\
\text { SIG(NF-1)-EMS(NF2-7) } S I G(N F-2)) / E M S(N F 2-6)\end{array}$ \\
\hline & 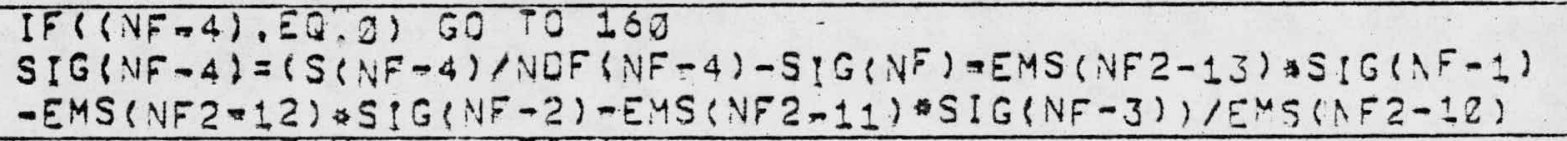 \\
\hline & 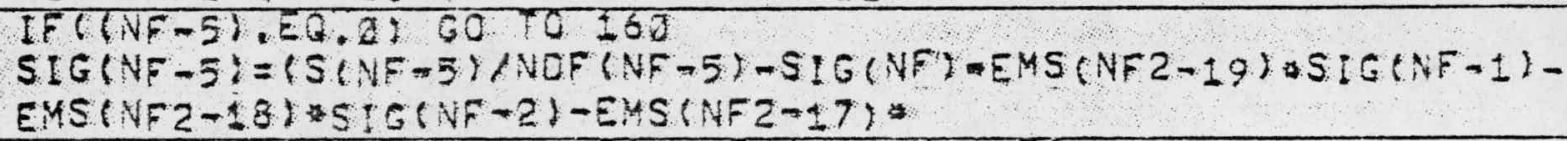 \\
\hline 160 & 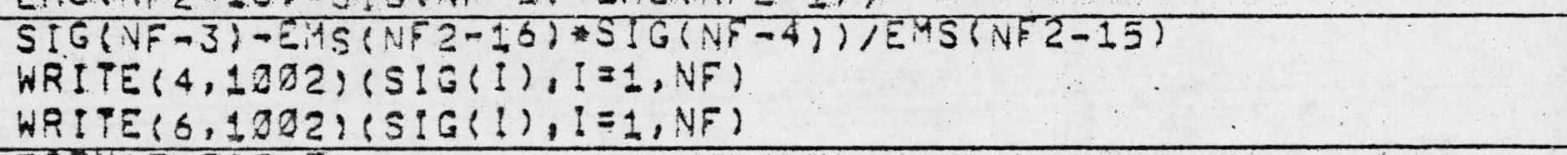 \\
\hline $\begin{array}{l}1002 \\
3050\end{array}$ & $\begin{array}{l}\text { FORMAT }(F 10,5) \\
\text { HRITE } 4,3050) \\
\text { FORMAT }(1 H Q \text {. IF WORE CATA,ENTER } 0, \text { IF MERGE,ENTER } 1 \text {. }\end{array}$ \\
\hline & $\begin{array}{l}\text { IF STOP,ENTER } 2 \text { T } \\
\text { READ(4,1D2D) IFLAG } \\
\text { IF(IFLAG.EQ.2) CALL EXIT }\end{array}$ \\
\hline 180 & $\begin{array}{l}\text { GO TO } 10 \\
\text { WRITE }(4,10 \pm 4) \\
\text { READ }(4,1015) \text { NF }\end{array}$ \\
\hline 3230 & 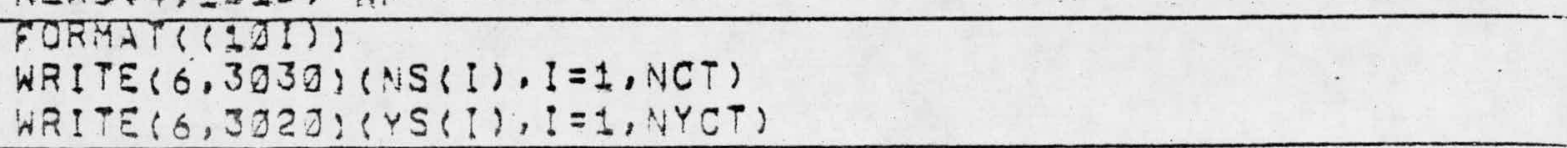 \\
\hline 3220 & $\begin{array}{l}F D F M A T((B F+D, 4)) \\
N F 1=N F+1 \\
N F Z=N F\end{array}$ \\
\hline
\end{tabular}


Table 15. (Cont.)

CALL ANESTU(NF, NS, YS, GM, S, NDF, EMS, IWK, IER) WRITE $(4,2280)$

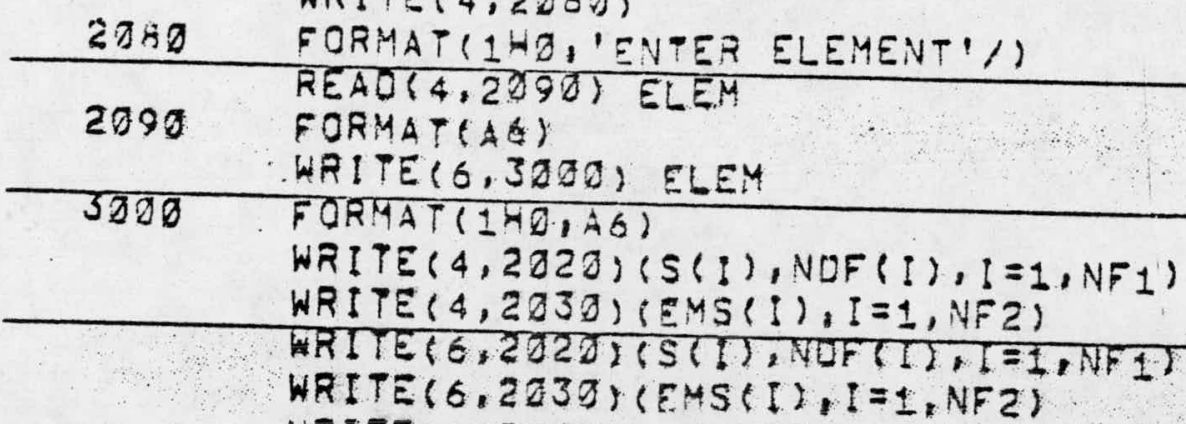

WRITE $(6 ; 2040)$ GM, IER IFLAG =

60 TO 150

END 
Table 16. Listing of output of program listed in Table 15.

\begin{tabular}{|c|c|c|c|c|c|c|}
\hline $\begin{array}{l}2.3711 \\
2.4771 \\
2.477\end{array}$ & $\begin{array}{l}2.3210 \\
2.3212 \\
2.3010\end{array}$ & $\begin{array}{l}2.3210 \\
2.4771 \\
2.477\end{array}$ & $\begin{array}{l}2.1761 \\
2.3712 \\
2.4771\end{array}$ & $\begin{array}{l}2.3213 \\
2.3012 \\
2.302=\end{array}$ & $\begin{array}{l}2,3010 \\
2,3.310 \\
x, 2030\end{array}$ & $\begin{array}{l}2.3213 \\
2.3212 \\
2\end{array}$ \\
\hline $\begin{array}{l}9.3000 \\
0.230\end{array}$ & $\begin{array}{l}0.0020 \\
0.0000\end{array}$ & $\begin{array}{l}0.090 x \\
0.0392\end{array}$ & 0.0204 & 0.0000 & 0.0000 & 2.2222 \\
\hline
\end{tabular}

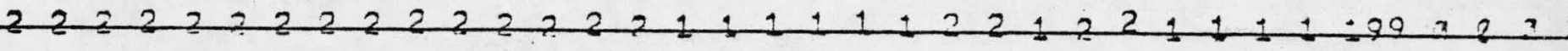
ROAN CREEK

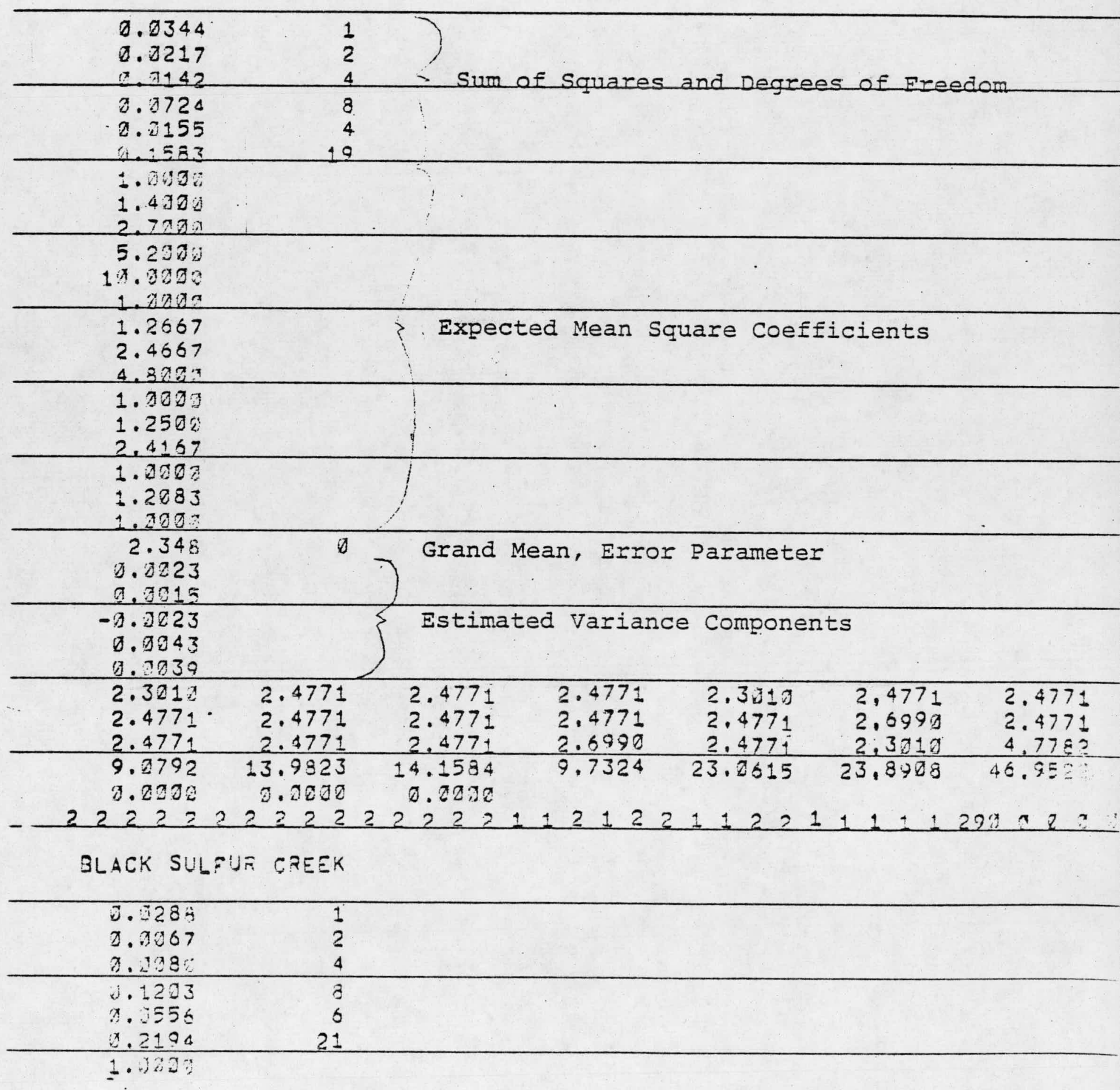


Table 16. (Cont.)

1.5455

$3.900:$

5.5455

11.000

1.0030

1.5212

2.9333

5.4545

1.0000

1.3202

2. 5333

1. 0000

1.3333

1.920

2.465

a. 3723

a. $\operatorname{lng} 4$

$-0.2251$

0. 2043

3.3293

\begin{tabular}{|c|c|c|c|c|c|c|}
\hline 2 & $\begin{array}{l}2 \\
2 \quad 2 \\
\end{array}$ & 2 & & $\begin{array}{l}2 \\
2 \\
\end{array}$ & $\begin{array}{l}2 \\
2\end{array}$ & \\
\hline $\begin{array}{l}2 \\
2\end{array}$ & 22 & 2 & & 2 & 2 & \\
\hline 2 & $\begin{array}{l}2 \\
2 \quad 1 \\
\end{array}$ & $\begin{array}{l}1 \\
2\end{array}$ & & $\begin{array}{l}1 \\
1 \\
\end{array}$ & $\begin{array}{l}1 \\
1 \\
\end{array}$ & \\
\hline $\begin{array}{l}1 \\
1\end{array}$ & $\begin{array}{r}2 \\
1 \quad 1 \\
\end{array}$ & 2 & & 2 & 1 & \\
\hline $\begin{array}{l}2.5010 \\
2.4774 \\
\end{array}$ & $\begin{array}{l}1 \\
2.3010 \\
2,3010\end{array}$ & $\begin{array}{r}2.3018 \\
2.4771 \\
\end{array}$ & $\begin{array}{l}2.1761 \\
2.3012 \\
\end{array}$ & $\begin{array}{l}2 \\
2.3010 \\
2.3010 \\
\end{array}$ & $\begin{array}{r}0 \\
2.3013 \\
2.3010 \\
\end{array}$ & $\begin{array}{l}2.3213 \\
2.32+3\end{array}$ \\
\hline $\begin{array}{l}2.4771 \\
2.3217 \\
2.4771\end{array}$ & $\begin{array}{l}2.3010 \\
2.4771 \\
2.6990\end{array}$ & $\begin{array}{l}2.4771 \\
2.4771 \\
2.4771\end{array}$ & $\begin{array}{l}2.4771 \\
2.3010 \\
2.4771\end{array}$ & $\begin{array}{l}2.3010 \\
2.4771 \\
2.4771\end{array}$ & $\begin{array}{l}2,4771 \\
2,4771 \\
2,4771 \\
\end{array}$ & $\begin{array}{l}2.4771 \\
2.4771 \\
2.4771\end{array}$ \\
\hline
\end{tabular}

$M N$

$0.145 i$

0.3632

0.7284

0. 1222

0.1927

7. 3711

3.5227

1. 2020

1. 4693

2.8429

5.3645

1.). 476 ?

2. .3524 
Table 16. (Cont.)

1. 200

1. 4727

2.8509

5.3727

$12.50 \mathrm{Jr}$

1.2008

1.3939

2.7200

5.1273

1.0000

1.2750

2.475 .

1. 0202

1.2708

1.200

2.400

0.1554

3.3223

Q.0009

$-\pi .0337$

7. 2039

2. 9071 
degree of freedom, then the expected mean square coefficients, the grand mean and error parameter. Finally, the estimated variance components are listed which were calculated using the sum of squares, degrees of freedom and expected mean square coefficients. The final output of nested model data with the streams combined is presented in the same manner as for the individual stream data output (note that some of NI values are missing due to lack of room on the left margin).

\section{Censored Data}

Another program (Table 17) which can handle censored sample distributions (Miesch, 1967b; Klusman and Edwards, 1976) was also used once to estimate the mean and variance of Cd. In the case of Cd, nearly $25 \%$ of the samples analyzed were below the detection limit (.04 ppm).

The test run of $\mathrm{Ba}$ and $\mathrm{Co}$ will be used to illustrate how this program is used. The following control cards are needed:

1) number of data sets and elements

2) name of elements

3) Iog option

4) form of data format

5) flag for end of data set

6) concentration where data is thrown out

7) detection Iimit for each element

For the test run of $\mathrm{Ba}$ and $\mathrm{Co}$, the control cards would be printed as follows: 
Table 17. Listing of censored data program.

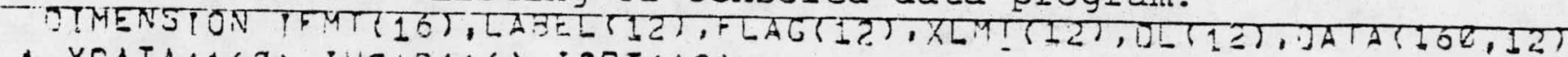
1. XCATA (167), IHEAD(16), IOFT(12)

C REZUU IN NUUGER OF DATA SETS, NUMBER OF ELMEUTS

GEAD 5,114$)$ MM,$M M M$

114 FORMAT (2!2)

C ZEAD IN ELEMENTS DETERMINED

TEAD (5,100) (LAEEL(1), I =1, MMM)

¿DJ FORMAT (12A4)

C ZEAD IN LOS OPTION

READ(5,117)(10PT (1), =1, MM, )

117 FORMAT (12A3)

C READ IN VAT!ABLE FORMAT FOA OATA

READ(5,1DI)(IFMT(I), I=1,16)

121 FORMAT (16A5)

- PEAD IN FLLG fEF END OF DATA SET

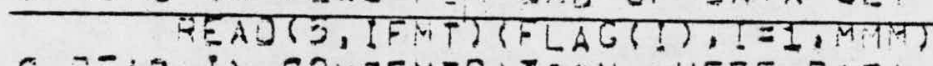

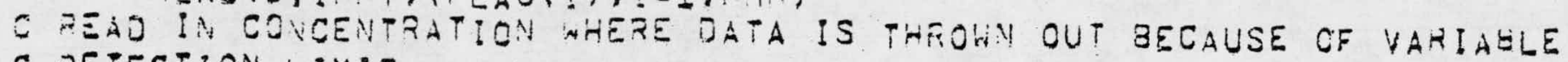

Z DETECTION LIM! :

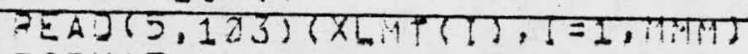

103 FORHAT(1255. D)

C READ IN DETECTION LIMIT FOR EACH ELE:AEIT

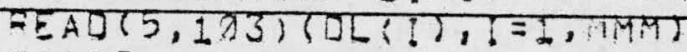

FACTR $=$ LLOG 110.$)$

$0012 \quad 4=1, M M$

C READ IN READING FOR EACH UताA उE!

READ $(5,115)($ IHEAO $(!), !=1,15)$

115 FORHAT (1SAS)

NतTE $(5.110)($ THEADT!). $=1.15)$

116 FORMAT $(1 H 1,1545)$

WR!TE $(6,129)$ (LABEL(I),I=1,MMM)

120 FRपA (1H, 12(4X,A4)

$N=1$

C READ DATA CHECIING FOR LAST SAMPLE (CAUTION-9999MIGHT WAVE TO BE

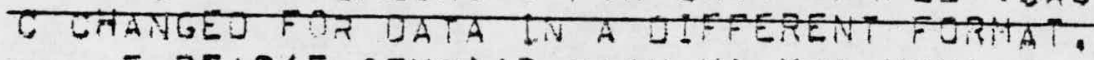

5 PEAD (5, IFMT) (OATA $(H, K), K=1, M M M)$

- IF(DATA $(N, 1), E Q .999 .9)$ G0 TO 7

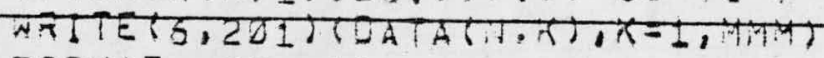

2D1 FORMAT (12F8.1)

C COUNT OATA

$M=N+1$

60 TO 5

E zEGIN LOOP THROUGH EACH ELEMENT

7 DO $\mathrm{J}=1$, MMH

C SET CDUNTEAS AND SUHS TO ZERO

St) $M X=0$.

गारातर $=1$.

$\because P=D$

$\because T=2$

C.

C WATCH FOR FLAG, SAMPLES GELOW DETECTION LPYIT

6 IF(JATA (N,J),EO.FLAG(J)) GO TO 1

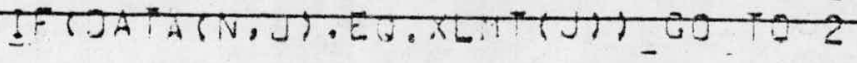




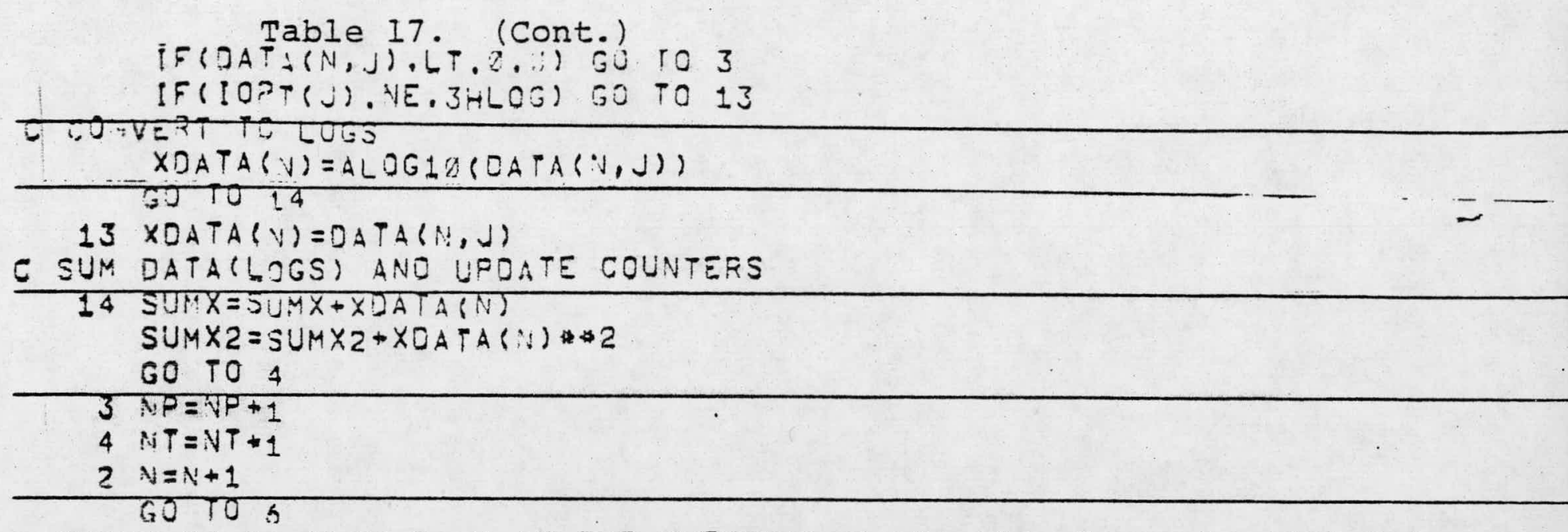

C GHECK TO BE SURE SOME OF THE DETERMIHATIONS ARE ABOVE THE DETECTION

L LIMIT

1 IF (NT, VE, D) GO TO 10

11 WRITE $(5,111)$ LABEL(J)

111 FORMAT ILHD, 33HNO AMALYTICAL DETERMIVATIONS FQR, A4, 21HABOVE DETECT $1 ! \operatorname{IN} L[4 ! T !$

GO TO 3

C CETEPMINE THE MUMGER OF DETERMINATIONS ABOVE THE DETECTICN LIMIT

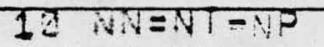

IF (NN.EQ.QD) GO TO 11

C CONVERT NUMBER TO FLOATING POINT

XIISFLDAT (NN)

C URITE SUMS

URITE $(6,112)$ LABEL(J), SUMX

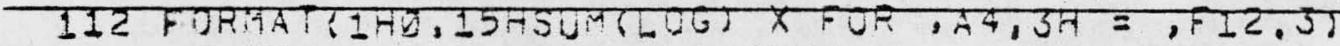

WRITE $(5,113)$ LABEL (J), SUMX2

113 FORMAT(1H, I8HSUM(LOG) $X * 2$ FOR, A4,3H $=, F 12,3)$

C DETEFMIVE दEUसEIRIC MEAM

$X Y E A P=S U M X / X N$

C IF LOG OPTION MOT TAKEN GO TO BRANCH

TF! IOFT(J).ME, उतLOG) JU TO 15

GMEAP $=E X P$ (FACTR XMEAP)

NRITE $(5,104)$ LABEL(J), GMEAP

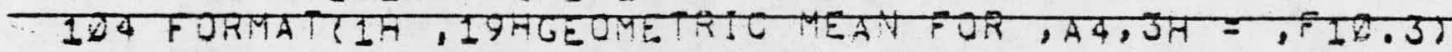

C OETERHINE GEOMETRIC DEVIATION

GDEV $=E X P(F A C T R *(S Q R T((1 . /((X N * 2)-X N)) *(((X N * S U M X 2)-(S U M X \backsim Z)))))$

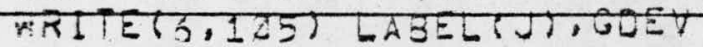

105 FORMAT:(1H, 24HGEOMETRIC DEV!AT!ON FOR, A4, 3H = ,F12.Z)

C DETERMINE SIGMA PRIME (USGS PROF. PAPER $574-8, P, 7$ )

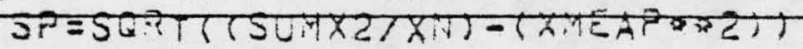

$S P F=E X P(F A C T R * S P)$

WRITE\{A,106) LABEL(J),SP

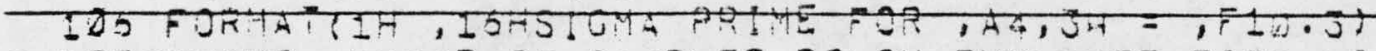

E DETERMINE VUMEER OF SAMPLES BELOW THE DETECTION LIMIT ANE PROFORTION

C ABOVE THE TETECTIOH LIM!T

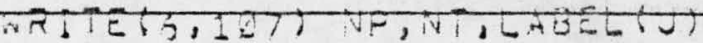

107 FORHATIIH, !3,27H SAMPLES OUT OF A TOTAL OF, I3,

134H ARE BELOW THE OETECTION LIMIT FOR,A4I 
Table 17. (Cont.)

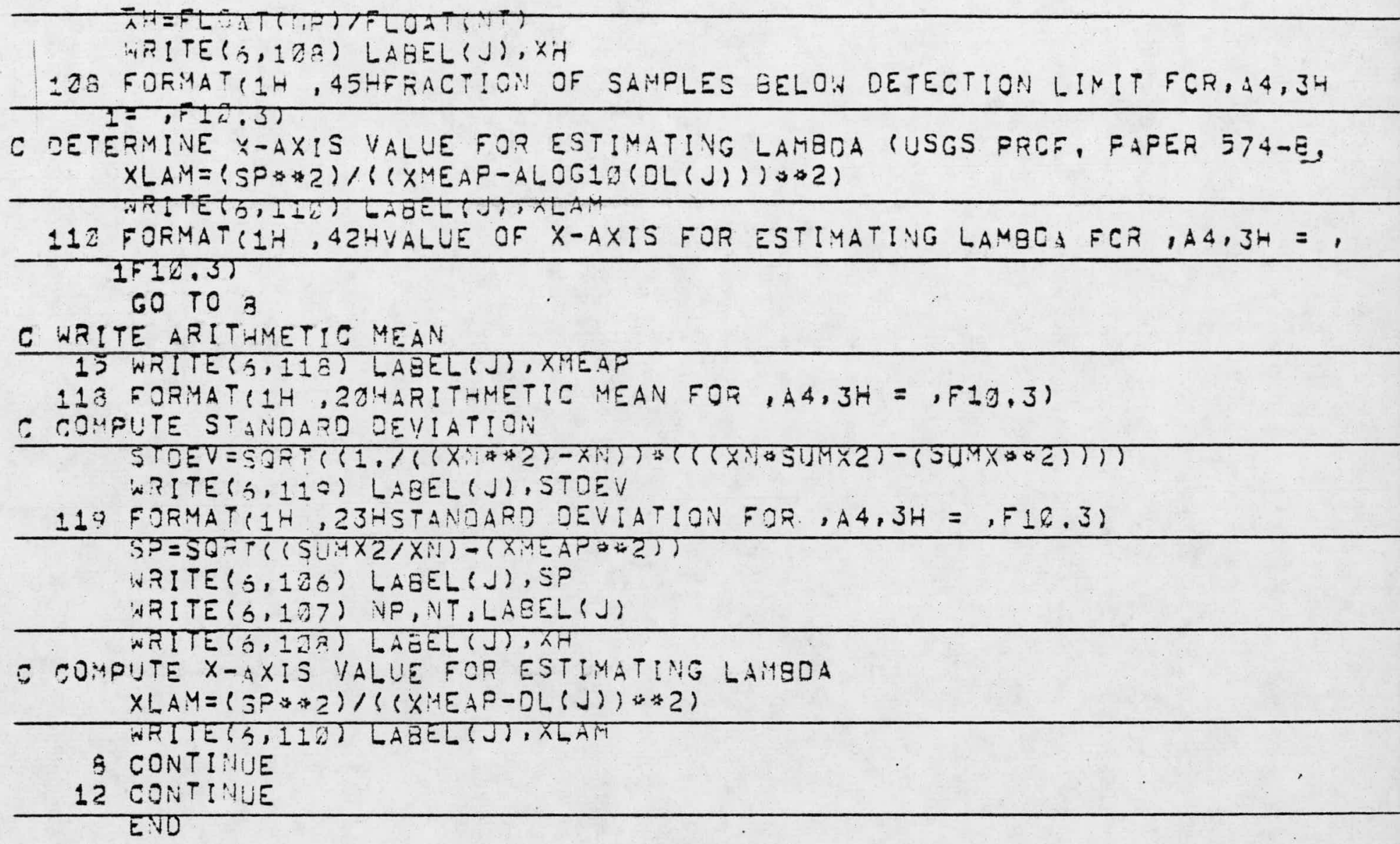




$$
\begin{aligned}
& \begin{array}{lllllllllllllll}
\text { Columns } & 1 & 2 & 3 & 4 & 5 & 6 & 7 & 8 & 9 & 10 & 11 & 12 & 13 & 14
\end{array} \\
& \text { 1) } 0 \quad 1 \quad 0 \quad 2 \\
& \text { 2) B A C } \\
& \text { 3) I } O G \text { L } O G \text { (log base } 10 \text { transformation) } \\
& \text { 4) ( } 2 \text { F } 5 \cdot 2) \\
& \text { 5) } 999 \cdot 999 \cdot 99 \\
& \text { 6) } 00000000000 \\
& \text { 7) } \quad 083
\end{aligned}
$$

For input data all values below the detection limit for each element must have a minus sign (see co input data, Table 18). 
Table 18. A. Input data for program listed in Table 17.

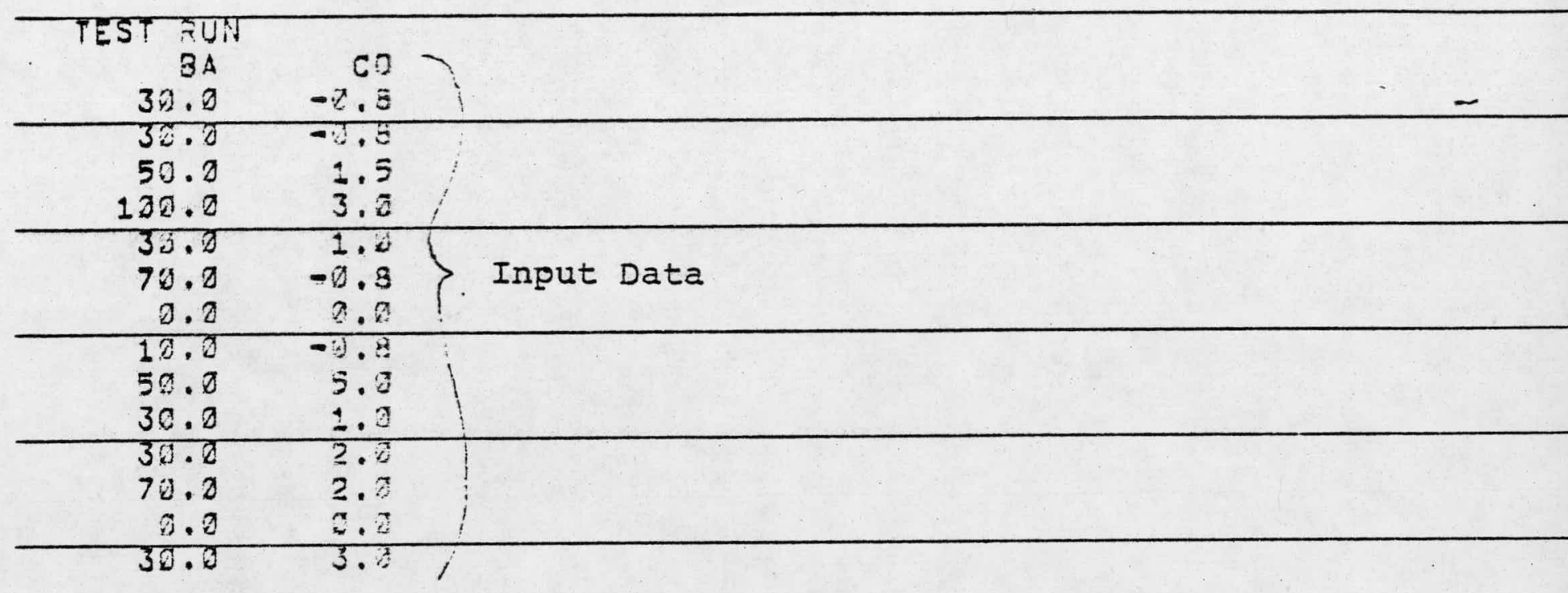

Table 18.B. Output data for program listed in Table 17.

SUM(LOG) X FCR SA $=18.951$

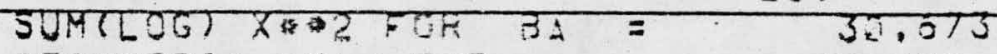

GEOMETRIC MEAN FOR AA $=37.952$

GEOMETRIC DEVIATION FOR BA $=24.821$

SIGMA FR!ME FOR $3 A=2.249$

O SAMPLES OUT OF A TOTAL OF 12 ARE EELOW THE DETECTION LIHIT FCF BA FRACTION OF SAMPLES JELOW DETECTION LIMIT FOR BA = O, ODO

VALUE OF $X-A X I S$ FOA ESTIMATING LAMROA TOR BA $=$ D.JणOO

SUM(LOG) $\times$ FOR CO $=2,431$

SUTILOG) XEDC FOR $C O=\quad 1.150$

GEQMETRIC MEAN FOR CO $=2,713$

GEOMETRIC DEVIATION FOR CO $=1.754$

SIGMA PRIME OOF $C O=0.220$

4 SAMPLES OUT OF A TOTAL OF 12 ARE BELON THE DETECTION LIMIT ECA CC FRACTION OF SAMFLES XELOU DETECTIOH LIMIT FOR CO =

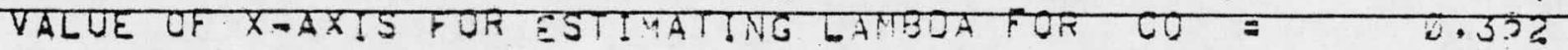


Table 19. Iisting of nested analyses for each stream location.

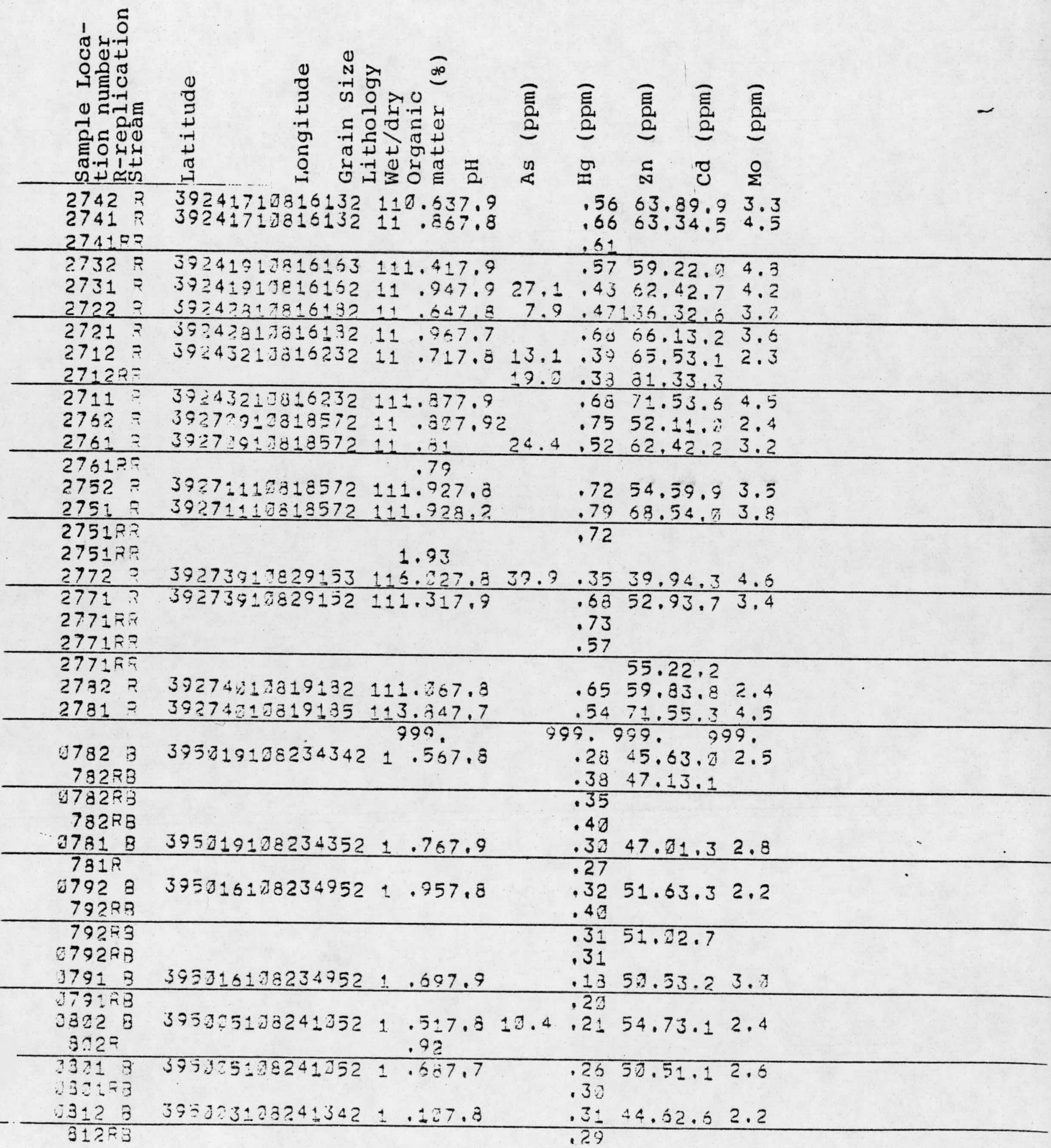


Table 19. (Cont.)

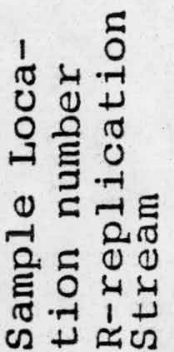

ग811 3 8112

031173

25820

938253

53813

$1092 \div$

3391

एंग 932

4922

3901

2321

$901 \mathrm{~F}$

$9912=394559 \pm 28274932+.877 .6$

91273

9119

2362

2961

$2342 ?$

$2342 R \%$

$234 \pm P$

2941700

$2932 P$

29B2RF

$2981=$

298180

2931R=

278120

$3002 ?$

$3002 R$

300525

उ.g2ap

$3025 \pi$

उत्या?

उУगIतP

$3 \% 22$ ?

3021 ?

$3221 R F$

$3742=$

$3541=$

$3241 R P$

$3 \pi 62=$

$3362 \mathrm{~F}$ 52

$37+63318827 \div 742 \quad 11.467 .6$

574629108272322

11.427 .7

$394627128272352 \quad 11.277 .7$

$3916 \% 21382747221.367 .7$

$39 \div 5 \quad 2128274742 \quad 12.197 .6$

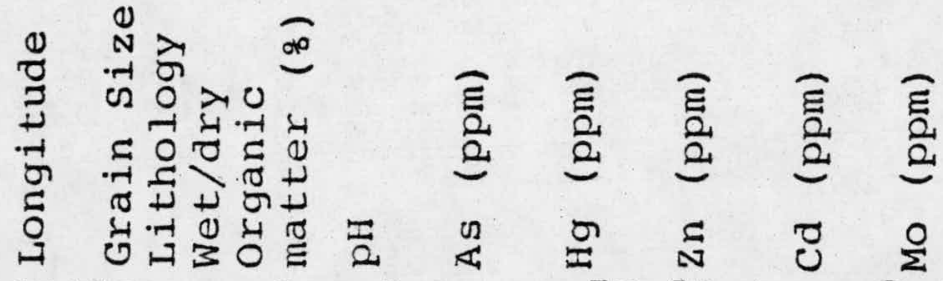

.5358 .14 .02 .4

\subsection{7 .5 \\ .55 \\ .8863 .93 .52 .6}

15.9

$.9 \mathrm{i}$

.4554 .59 .92 .3

4

28.64 .74 .330

.4302 .44 .61 .9

2.4

.4136 .29 .96 .4

.4059 .5

.4650 .59 .93 .2

.3952 .2

$39455913827492211.107 .7 \quad 12.5 .4550 .02 .52 .8$ $999 . \quad 999.999 .999$.

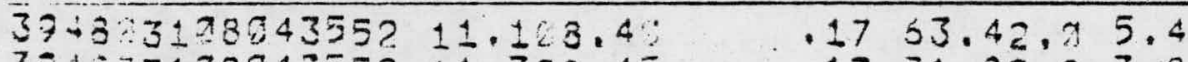

$39433310804355211.308 .45 \quad .1771 .39 .73 .3$

394813198043552112194

.1762 .20 .92 .3

.1762 .1

$334303198043552 \quad 11.448 .45$

$.26 \quad 72.73 .53 .8$

.3.

3947461282529521.945 .45

$394746+78957852 \quad 11,458.53$

.22

.23

.2478 .34 .2

.30

63.23 .8

.24

39474610805085211.268 .35

8,55

.1878 .73 .36 .7

.23

.19

$394745178050952 \quad 11.228,55$

69.82 .7

.2171 .63 .24 .5

.21

.2061 .39 .94 .3

$394802128974252 \div .923 .05$

$.3967 .33 .8 \quad 4.3$

$396323 \pm 380742521.813 .33$

$394802175074742 \div .948 .17$

.42

.3071 .59 .92 .9

$3943^{7} 2198771752 \quad 11.158 .37$

$.2 \div 65.72 .74 .9$

3943241283758521.733 .13

3.27
.29

.1367 .53 .15 .2 
Table 19. (Cont.)

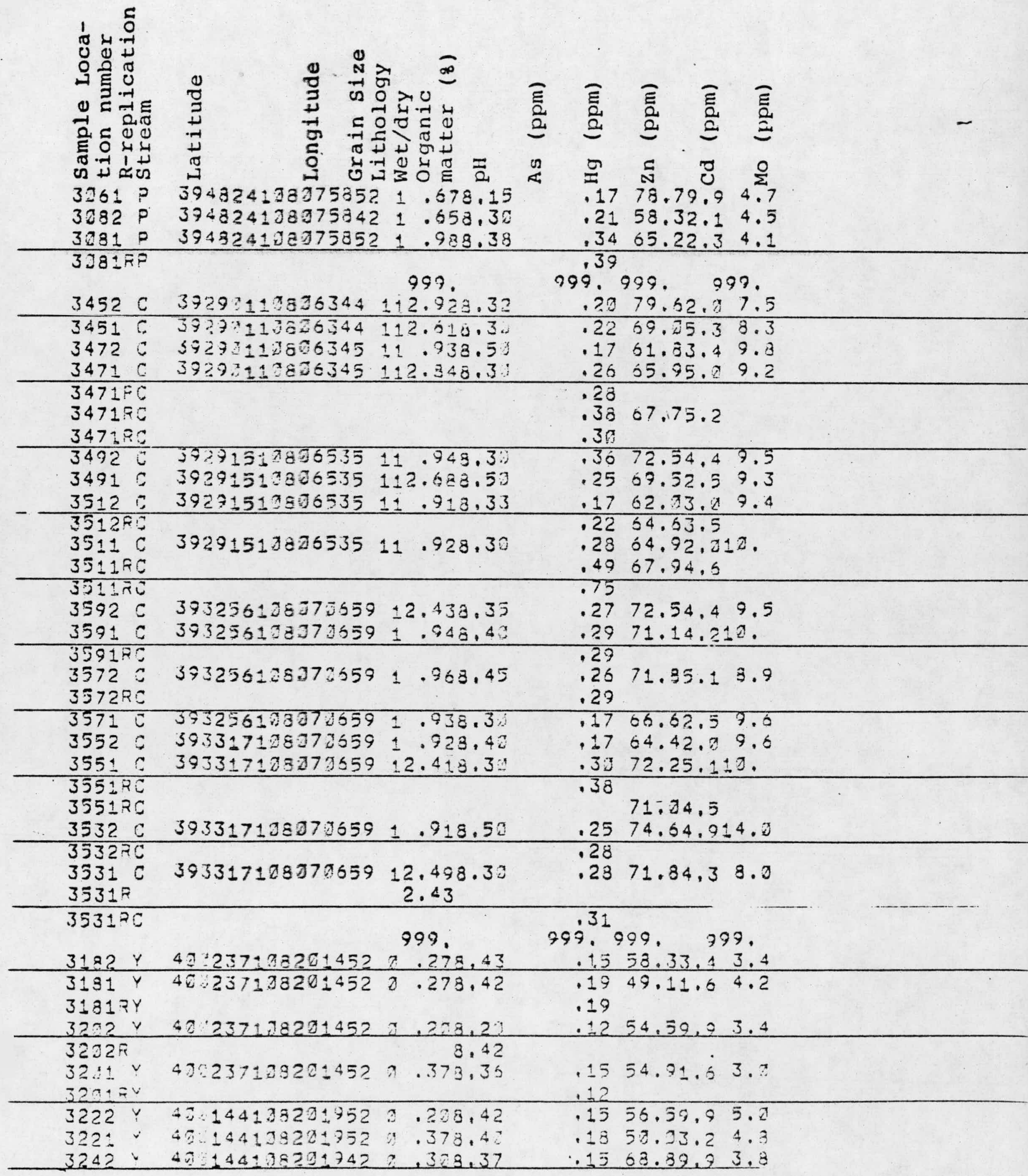


Table 19. (Cont.)

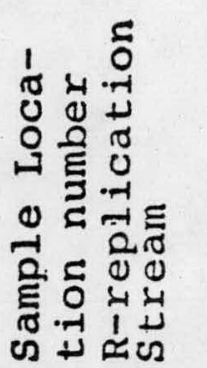

$3241 Y$

3102 Y $3102 F Y$

$3102 \mathrm{~F}$

31027

$3101 \times 395814123224832 \div .143 .45$

3122 Y $395814130224332 \Xi .118 .50$ 3122 ? $3122 R^{4}$

$31222 Y$

$31227 Y$

3121

$3121 R Y$

3142

3141 Y

3162

$31625 Y$

$3161 Y$

\subsection{5}

$395752 \pm 2823 \pm 742 \pi .168 .60$

$393752128231732 \approx .248 .2$

.493 .35
崩

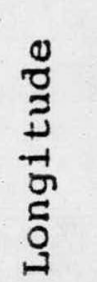

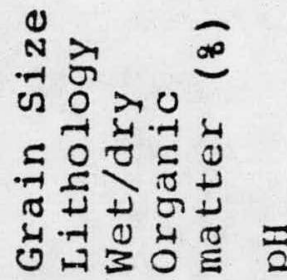

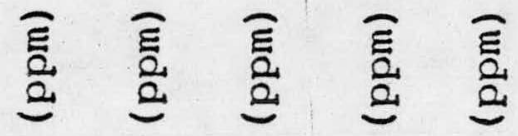

4031441982219522.918 .27

$3958141082243320.918 .4 \%$

8.53

ㄷำ ช

.1259 .59 .93 .5

.1744 .79 .94 .1 49.3

.1252 .19 .92 .3

.1) $44,21.8$

.16

.15

$15 \quad 47.21 .62 .6$

16

.1352 .62 .1

.1354 .99 .93 .3

, 1847.71 .31 .6$

.16

.1354 .99 .93 .3

399. 999.999. 
Table 20. Analysis of Variance Results for the Nested Stream Models.

Analysis of Variance of Individual Streams for Mo

Roan Creek

Source of Variance SS DF MS $\underline{\text { S }}$ Critical values

$2 \mathrm{k}$ segments

$200 \mathrm{~m}$ segments

20 m segments

Samples

Total

$\begin{array}{lllll}.00517 \quad 1 & .00517 & .36 & F .05(1,2)=18.5\end{array}$

$\begin{array}{lllll}.02885 & 2 & .0144 & 2.28 & \mathrm{~F} .05(2,4)=6.94\end{array}$

$\begin{array}{lllll}.02518 & 4 & .0063 & .46 & \text { F.05 } \\ .05,8)=3.84\end{array}$

$.11064 \quad 8 \quad .01384$

Black Sulfur Creek

216 segments
$200 \mathrm{~m}$ segments
$20 \mathrm{~m}$ segments
Samples
Replications
Total

Piceance Creek

$2 \mathrm{k}$ segments $200 \mathrm{~m}$ segments $20 \mathrm{~m}$ segments

Samples

Total

\section{Parachute Creek}

$2 \mathrm{k}$ segments $200 \mathrm{~m}$ segments $20 \mathrm{~m}$ segments

Samples

Total

\section{Yellow Creek}

$2 \mathrm{k}$ segments $200 \mathrm{~m}$ segments $20 \mathrm{~m}$ segments

Samples

Total

$$
\begin{aligned}
& \begin{array}{llll}
.05734 & 1 & .05734 \quad 7.60
\end{array} \\
& \begin{array}{llll}
.01507 & 2 & .00754 & 1.19
\end{array} \\
& .02527 \\
& .27282 \\
& .00616 \\
& .37666 \\
& .00632 \\
& .19 \\
& 8 \quad .034101 \pm .07 \\
& \underline{2} .00308 \\
& 17
\end{aligned}
$$$$
\text { F. } 05(1,2)=18.5
$$$$
\text { F.05 }(2,4)=6.9
$$$$
\text { F. } 05(4,8)=3.8
$$

.00281

.02708

.06706

.07923

.17618

.00464

.00548

.00830

.03223

.05065

.06803

.01555

.05674

.08794

.22825

$$
\begin{array}{rrr}
1 & .00281 & .21 \\
2 & .01354 & .81 \\
4 & .01677 & 1.48 \\
\frac{7}{14} & .01132 &
\end{array}
$$

F. $05(1,2)=18.5$ F.05 $(2,4)=6.9$ F. $05(4,7)=4.1$ 
Table 20 (Cont.)

Analysis of Variance of All Streams for Mo

\begin{tabular}{|c|c|c|c|c|c|}
\hline ource of Varian & & $\underline{D F}$ & MS & $\underline{\mathbf{F}}$ & Sitical Values \\
\hline $\begin{array}{l}\text { treams } \\
\mathrm{k} \text { segments } \\
00 \mathrm{~m} \text { segments } \\
0 \mathrm{~m} \text { segments } \\
\text { amples } \\
\text { eplications }\end{array}$ & $\begin{array}{r}2.65804 \\
.11617 \\
.14147 \\
.31980 \\
.47102 \\
.00616\end{array}$ & $\begin{array}{r}4 \\
5 \\
10 \\
20 \\
38 \\
2\end{array}$ & $\begin{array}{l}.66451 \\
.02324 \\
.01414 \\
.01599 \\
.01240 \\
.00308\end{array}$ & $\begin{array}{c}28.54 * \\
1.64 \\
.88 \\
1.29 \\
3.26\end{array}$ & $\begin{array}{l}F .05(4,5)=5.2 \\
F .05(5, I 0)=3.3 \\
\text { F.US }(1 U, 2 U)=\bar{U} .4 \\
F .05(20,30)=1.9 \\
\text { F.05 }(30,2)=19.5\end{array}$ \\
\hline t & & & & & \\
\hline
\end{tabular}

Analysis of Variance of Individual Streams for Hg

Roan Creek

$2 \mathrm{k}$ segments

$200 \mathrm{~m}$ segments

$20 \mathrm{~m}$ segments

Samples

Replications

Total

\section{Black Sulfur Creek}

$2 \mathrm{k}$ segments

$200 \mathrm{~m}$ segments

$20 \mathrm{~m}$ segments

Samples

Replications

Total

\section{Piceance Creek}

$2 \mathrm{k}$ segments

$200 \mathrm{~m}$ segments

$20 \mathrm{~m}$ segments

Sample

Replications

Total

\section{Parachute Creek}

$2 \mathrm{k}$ segments

$200 \mathrm{~m}$ segments

$20 \mathrm{~m}$ segments

Samples

Replications

Total

$$
\begin{array}{lll}
.02560 & 1 & .02560 \\
.02466 & 2 & .02233 \\
.02576 & 4 & .00644 \\
.13515 & 8 & .01689 \\
.00758 & \frac{5}{.01876} & .00152 \\
\hline 20 &
\end{array}
$$

2.08

1.91

F. $05(1,2)=18.5$

.38

11. I*

F. $05(2,4)=6.9$

F. $05(4,8)=3.8$

F. $05(8,5)=4.8$
.21608

.03194

.21238

.23702

.02985

.72726

$$
\begin{array}{rr}
1 & .21608 \\
2 & .01597 \\
4 & .05310 \\
8 & .02963 \\
14 & .00213 \\
29 &
\end{array}
$$

.04901

.03661

.15405

.16721

.02841

.4352

$$
\begin{array}{rl}
1 & .04901 \\
2 & .01831 \\
4 & .03851 \\
8 & .0209 \\
11 & .00258 \\
26 &
\end{array}
$$

$$
.00475
$$

.04236

.02976

.33134

.12224

.53045
13.53 .30

1.79 $13.91 *$

F. $05(1,2)=18.5$ F. $05(2,4)=6.9$ F. $05(4,8)=3.8$ F. $05(8,4)=2.7$
2.68

.48

1.84

$8.10 *$
F. 05 $(1,2)=18.5$

F. $05(2,4)=6.94$

F. $05(4,8)=3.84$

F. $05(8,4)=2.95$

*indicates $F$ value larger than the $95 \%$ confidence critical value. 
Table 20 (Cont.)

Source of Variance $\quad \underline{S S} \quad \underline{D F} \quad \underline{M S} \quad \underline{F}$ Critical values

Yellow Creek

$2 \mathrm{k}$ segments
$200 \mathrm{~m}$ segments
$20 \mathrm{~m}$ segments
Samples
Replications
Total

.000801 .00080

$.00019 \quad 2 \quad .00010$

$.04176 \quad 4 \quad .01044$

$.03810 \quad 8 \quad .00476$

$.04327 \quad 7 \quad .00618$

8.00

F. $05(1,2)=18.5$

.01

F. $05(2,4)=6.94$

2.19

F. $05(4,8)=3.84$

.77

F. $05(8,7)=3.73$

Analysis of Variance of All streams for $\mathrm{Hg}$

\section{Streams \\ $2 \mathrm{k}$ segments \\ $200 \mathrm{~m}$ segments \\ $20 \mathrm{~m}$ segments \\ Samples \\ Replications}

Total

$$
\begin{array}{rrr}
4.40435 & 4 & 1.10105 \\
.29625 & 5 & .05925 \\
.13575 & 10 & .01357 \\
.46371 & 20 & .62319 \\
.90887 & 40 & .02272 \\
.23135 & 48 & .00482
\end{array}
$$
41.10105
5.05925
$10 \quad .01357$
40
.02272
.00482
$18.58 * \mathrm{~F} .05(4,5)=5.19$
$4.37 * \mathrm{~F} .05(5,10)=3.33$
$.59 \mathrm{~F} .05(10,20)=2.35$
1.02 F.05 $(20,40)=1.84$
$4.71 * \mathrm{~F} .05(40,48)=1.60$

Analysis of Variance of Individual Streams for $\mathrm{zn}$

Roan Creek

$2 \mathrm{k}$ segments

$200 \mathrm{~m}$ segments

$20 \mathrm{~m}$ segments

Samples

Replications

Total

Black Sulfur Creek

$2 \mathrm{k}$ segments

$200 \mathrm{~m}$ segments

$20 \mathrm{~m}$ segments

Samples

Replications

Total

\section{Piceance Creek}

$2 \mathrm{k}$ segments

$200 \mathrm{~m}$ segments

$20 \mathrm{~m}$ segments

Samples

Replications

Total

$$
\begin{aligned}
& 1.04780 \\
& .01546 \\
& .00925 \\
& .00904 \\
& \text { ․ } .00229
\end{aligned}
$$

3.09

1.67

1.02

3.95

F. $05(1,2)=18.5$

F. $05(2,4)=6.94$

F. $05(4,8)=3.84$

F.05 $(8,2)=19.37$
.01670

.00543

.00945

.01140

.00051

.04348

.00048

.00191

.00642

.00925

.00010

.0182

$$
\begin{array}{cc}
1 & .01670 \\
2 & .00272 \\
4 & .00236 \\
8 & .00143 \\
4 & .00013 \\
\hline 19 &
\end{array}
$$

6.44

1.15

1.65

$11.00 *$

F. $05(1,2)=18.5$

F. $05(2,4)=6.94$

$F^{\circ}-(4.8)=2.84$

$$
\begin{array}{ll}
1 & .00048 \\
2 & .00096 \\
4 & .00162 \\
8 & .00116 \\
3 & .00003 \\
\hline
\end{array}
$$

.50

.59

F. $05(1,2)=18.5$

F. $05(2,4)=6.94$

1.40

38.67 *

$\mathrm{F}$

$.05(4,8)=3.84$

F.05 $(8,3)=8.85$ 
Table 20 (Cont.)

Source of variance $\underline{S S} \quad \underline{D E} \quad \underline{M S} \quad \underline{F}$ Critical values

Parachute Creek

$2 \mathrm{k}$ segments

$200 \mathrm{~m}$ segments

$20 \mathrm{~m}$ segments

Samples

Replications

Total

Yellow Creek

$2 \mathrm{k}$ segments

$200 \mathrm{~m}$ segments

$20 \mathrm{~m}$ segments

Samples

Replications

Total

$$
\begin{aligned}
& .00176 \quad 1 \quad .00176 \\
& .000352 .00018 \\
& .006904 .00173 \\
& .00540 \quad 8 \quad .00068 \\
& .00045 \quad 4 \quad .00011 \\
& .01486 \quad 19
\end{aligned}
$$

$$
\begin{array}{lll}
.01248 & 1 & .01248 \\
.00571 & 2 & .00286 \\
.01281 & 4 & .00320 \\
.01880 & 8 & .00235 \\
.00099 & 2 & .00050
\end{array}
$$

\subsection{6}

.89

F. $05(1,2)=18.5$

F. $05(2,4)=6.94$

$1.36 \quad F .05(4,8)=3.89$

$4.74 \quad \mathrm{~F}_{.05}^{.05}(8,2)=19.37$

$\begin{aligned} & 9.78 \text { F. } 05(1,2)=18.5 \\ & .10 \text { F. } \\ & .05(2,4)=6.94\end{aligned}$

$2.54 .05(4,8)=3.84$
$6.14 * F .05(8,4)=6.04$

Analysis of Variance of all Streams for $\mathrm{zn}$

Streams
$2 \mathrm{k}$ segments
$200 \mathrm{~m}$ segments
$20 \mathrm{~m}$ segments
Samples
Replications
Total

Streams

$2 \mathrm{k}$ segments

$20 \mathrm{~m}$ segments

Samples

Total

$\begin{array}{lrl}.24818 & 4 & .06205 \\ .07923 & 5 & .01585 \\ .04429 & 10 & .004429 \\ .07259 & 20 & .00363 \\ .11718 & 40 & .00293 \\ .00662 & 15 & .00044 \\ .56809 & \frac{15}{94} & \end{array}$

$3.91 F .05(4,5)=5.19$

$3.58 * F^{*} .05(5,10)=3.33$

$1.22 \quad F .05(10,20)=2.35$

$1.24 \quad F .05(20,40)=1.84$

$6.66 * \mathrm{~F} .05(40,15)=2.20$

Analysis of Variance of Individual Streams for organic Carbon

Roan Creek

$2 \mathrm{k}$ segments

$200 \mathrm{~m}$ segments

$20 \mathrm{~m}$ segments

Samples

Total

\section{Black Sulfur Creek}

$2 \mathrm{k}$ segments

$200 \mathrm{~m}$ segments

$20 \mathrm{~m}$ segments

Samples

Replications

Total

$$
\begin{array}{lrlll}
.24716 & 1 & .24716 & 2.57 & F .05(I, 2)=18.5 \\
.19265 & 2 & .09635 & 1.27 & F .05(2,4)=6.94 \\
.30408 & 4 & .07602 & 1.21 & F .05(4,8)=3.84 \\
.50418 & \frac{8}{1.06302} & .061 .00 * & F .05(8,2)=19.37 \\
\hline .24817 & 17 & & & .05
\end{array}
$$$$
2.57
$$$$
1.27
$$$$
\text { F. } 05(1,2)=18.5
$$$$
\text { F. } 05(2,4)=6.94
$$$$
1.21
$$$$
\text { F.05 }(4,8)=3.84
$$

.


Table 20 (Cont.)

Source of Variance SS DF MS $\underline{F}$ Critical Values

Piceance Creek

$2 \mathrm{k}$ segments

$200 \mathrm{~m}$ segments

$20 \mathrm{~m}$ segments

Samples

Total

$.10643 \quad 1 \quad .10643$

9.43

F. $05(1,2)=18.5$

.022562 .01125

3.50

F. $05(2,4)=6.94$

.01291

.00323

$.04740 \quad 8 \quad .00593$

.54

F.O5 $(1,8)=3.01$

$.18930 \quad 15$

Parachute Creek

$2 \mathrm{k}$ segments

$200 \mathrm{~m}$ segments

$20 \mathrm{~m}$ segments

Samples

Replications

Total

Yellow Creek

$2 \mathrm{k}$ segments

$200 \mathrm{~m}$ segments

$20 \mathrm{~m}$ segments

Samples

Replications

Total

$$
\begin{array}{lll}
.00439 & 1 & .00439 \\
.00544 & 2 & .00270 \\
.00250 & 4 & .00063 \\
.00255 & 8 & .00032 \\
.00006 & \frac{1}{16} &
\end{array}
$$$$
1.63
$$$$
4.29
$$$$
1.97
$$$$
\text { F. } 05(1,2)=18.5
$$$$
\text { F. } 05(2,4)=6.95
$$$$
\text { F. } 05(4,8)=3.84
$$$$
5.33
$$$$
\text { F. } 05(8,1)-238.9
$$

Analysis of Variance of all Streams for organic Matter

Streams
$2 \mathrm{k}$ segments
$200 \mathrm{~m}$ segments
$20 \mathrm{~m}$ segments
Samples
Replications
Total

Streams

$200 \mathrm{~m}$ segments

$20 \mathrm{~m}$ segments

Samples

Total

9.67667

1.17044

.49915

.54738

1.23607

.00033

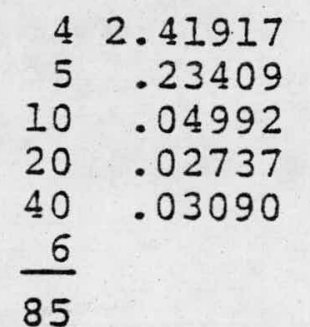
$10.33 * \mathrm{~F} .05(4,5)=5.19$
$4.69 * F .05(5,10)=3.33$
$1.82 \quad F .05(10,20)=2.35$
$.89 \mathrm{~F}_{.05}(20,40)=1.84$
$5.15 *$
F.05 $(40,6)=3.77$




\section{REFERENCES}

Anderson, R. L., and Bancroft, T. A., 1952, Statistical Theory in Research, New York, McGraw-Hill Book Co., Inc., Chapter 22 .

Cashion, W. B., Donnell, John R., 1974, Revision of Nomenclature of the Upper Part of the Green River Formation, Piceance Creek Basin, Colorado, and Eastern Uinta Basin, Utah: U.S. Geol. Survey Bull. 1394-G, P. G1-G9.

Donnell, John R., 1961, Tertiary Geology and Oil-Shale Resources of the Piceance Creek Basin Between the Colorado and White Rivers, Northwestern Colorado: U.S. Geol. Survey Bull. 1082-I, p. 842-860.

Gough, Larry P., and Shacklette, Hansford T., Toxicity of Selected Elements to Plants, Animals, and Man -- An Outline, in U.S. Geological Survey, Geochemical Survey of the Western Energy Regions: U.S. Geological Survey, open file report 76-729; Appendix IV, p. 25 .

Hatch, Ronald $W$. and ott, Welland, L., 1968, Determination of Sub-Microgram Quantities of Mercury by Atomic Absorption Spectrophotometry: Analytical Chemistry, August 1968, p. 2085-2087.

International Mathematical and Statistical Iibraries, Inc., 1975, IMSI Library 2: Vol. I (Fortran-10, DEC System 10), p. ANESTU-1, ACRAN-1.

Keith, John R., Anderson, Barbara, M., and Connor, Jon J., 1974, Trace Metal Variation in the Powder River Basin: U.S. Geol. Survey Open-file Report No. 74-250, p. 14 .

Rlusman, Ronald W., 1976, Computer Program to Calculate GM and GD of Complete and Censored Data, Unpublished Research.

Krauskopf, Konrad B., 1967, Introduction to Geochemistry, McGraw-Hill Book Co., N.Y., P. 639-640.

Krumbein, W. C., and Slack, H. A., 1956, Statistical analysis of low-level radioactivity of Pennsylvanian black fissile shale in Illinois: Geol. Soc. America Bull., v. 67, p. $739-762$.

Leone, F. C., Nelson, L. S., Johnson, N. L., and Eisen, S. S., 1968, Sampling Distributions of Variance Components II. Empirical Studies of Unbalanced Nested Designs,* Techonometrics, Vol. 10, No. 4, Nov. 
Levenson, A. A., 1974, Introduction to Exploration Geochemistry, Applied Publishing, Ltd., Calgary, Alberta, Canada,

McNeal, James M., Feder, Gerald L., Ringrose, Charles D., and Klusman, Ronald w., Stream Sediment Chemistry in the oil Shale Region, in U.S. Geological Survey, Geochemical Survey of the Western Energy Regions: U.S. Geological Survey, Open File Report 76-724, p. 121-130.

Mẹlen, Robert R., and Glaze, Michael, L., 1973, Analytical methods and analytical chemistry laboratory: unpublished research in conjunction with the molybdenum project: University of Colorado, Boulder, Colorado, p. 15-18.

Miesch, A. T., 1976a, Geochemical Survey of Missouri - Methods of Sampling, Laboratory Analysis, and Statistical Reduction of Data: U.S. Geol. Survey Prof. Paper 954-A, p. A28-A32.

1976b, Sampling Designs for Geochemical Surveys Syllabus for a short course: U.S. Geological Survey, Open-file report $76-772$, p. 3 and p. 91-105.

$1967 \mathrm{~b}$, Methods of Computation for Estimating Geochemical Abundances: U.S. Geol. Survey Prof. Paper 547-B, p. 87 .

Ringrose, Charles D., Klusman, Ronald W., and Dean, Walter P., 1976, Soil Chemistry in the Piceance Creek Basin, in U.S. Geological Survey, Geochemical Survey of the Western Energy Regions: U.S. Geological Survey, Open-file report 76-729, p. 101-111.

Roehler, Henry W., 1974, Depositional Environments of Rocks in the Piceance Creek Basin, Colorado: Guidebook to the Energy Resources of the Piceance Creek Basin, Colorado, D. Keith Murray, ed., Denver, Colo., Rocky Mt. Assoc. Geologists, pp. 57-64.

Smith, J. W., 1974, Geochemistry of oil shale genesis in Colorado's Piceance Creek Basin, in Guidebook to the Energy Resources of the Piceance Creek Basin, Colorado. Murray, D. K., ed., Denver, Rocky Mtn. Assoc. Geol., pp. $71-79$.

Walkey, A., and Black, I. A., 1934, An examination of the Degtjareff method for determining soil organic matter and a proposed modification of the chromic acid titration method: Soil sci. 37, 29-38.

Walpole, Ronald E., Myers, Raymond H., 1972, Probability and statistics for Engineers and Scientists: New York, Macmillan Publishing Co., Inc., 242 p. 